\title{
CONTROLE DE Blattella germanica (L.) COM Metarhizium anisopliae E INSETICIDAS REGULADORES DE CRESCIMENTO
}

\author{
ROGÉRIO BIAGGIONI LOPES
}

Tese apresentada à Escola Superior de Agricultura

“Luiz de Queiroz", Universidade de São Paulo, para obtenção do título de Doutor em Ciências, Área de Concentração: Entomologia.

P I R A C I C A B A

Estado de São Paulo - Brasil

Janeiro -2005 


\title{
CONTROLE DE Blattella germanica (L.) COM Metarhizium anisopliae E INSETICIDAS REGULADORES DE CRESCIMENTO
}

\author{
ROGÉRIO BIAGGIONI LOPES \\ Engenheiro Agrônomo
}

Orientador: Prof. Dr. SÉRGIO BATISTA ALVES

\footnotetext{
Tese apresentada à Escola Superior de Agricultura

"Luiz de Queiroz", Universidade de São Paulo, para obtenção do título de Doutor em Ciências, Área de Concentração: Entomologia.
}

P I R A C I C A B A

Estado de São Paulo - Brasil

Janeiro - 2005 
Dados Internacionais de Catalogação na Publicação (CIP) DIVISÃO DE BIBLIOTECA E DOCUMENTAÇÃO - ESALQ/USP

Lopes, Rogério Biaggioni

Controle de Blattella germanica (L.) com Metarhizium anisopliae e inseticidas reguladores de crescimento / Rogério Biaggioni Lopes. - - Piracicaba, 2005.

121 p. : il.

Tese (Doutorado) - - Escola Superior de Agricultura Luiz de Queiroz, 2005. Bibliografia.

1. Baratas 2. Controle biológico 3. Controle químico 4. Fungo

entomopatogênico 5. Praga urbana 6. Regulador de crescimento I. Título

CDD 632.722

"Permitida a cópia total ou parcial deste documento, desde que citada a fonte - O autor" 


\section{AGRADECIMENTOS}

Ao Prof. Dr. Sérgio Batista Alves, pela orientação, confiança, amizade e respeito demonstrados durante nosso convívio.

Aos professores do Departamento de Entomologia, Fitopatologia e Zoologia (ESALQ/USP) pelos valiosos conhecimentos por mim adquiridos no decorrer do curso de pós-graduação.

À bióloga Solange Aparecida Vieira, técnica do Laboratório de Patologia e Controle Microbiano de Insetos pelo auxílio na elaboração e condução dos experimentos.

A todos os colegas do curso de pós-graduação em Entomologia, em especial à equipe do Laboratório de Patologia e Controle Microbiano de Insetos, pela amizade e companheirismo.

À CAPES, pela bolsa de estudos que possibilitou a execução desse trabalho. 


\section{SUMÁRIO}

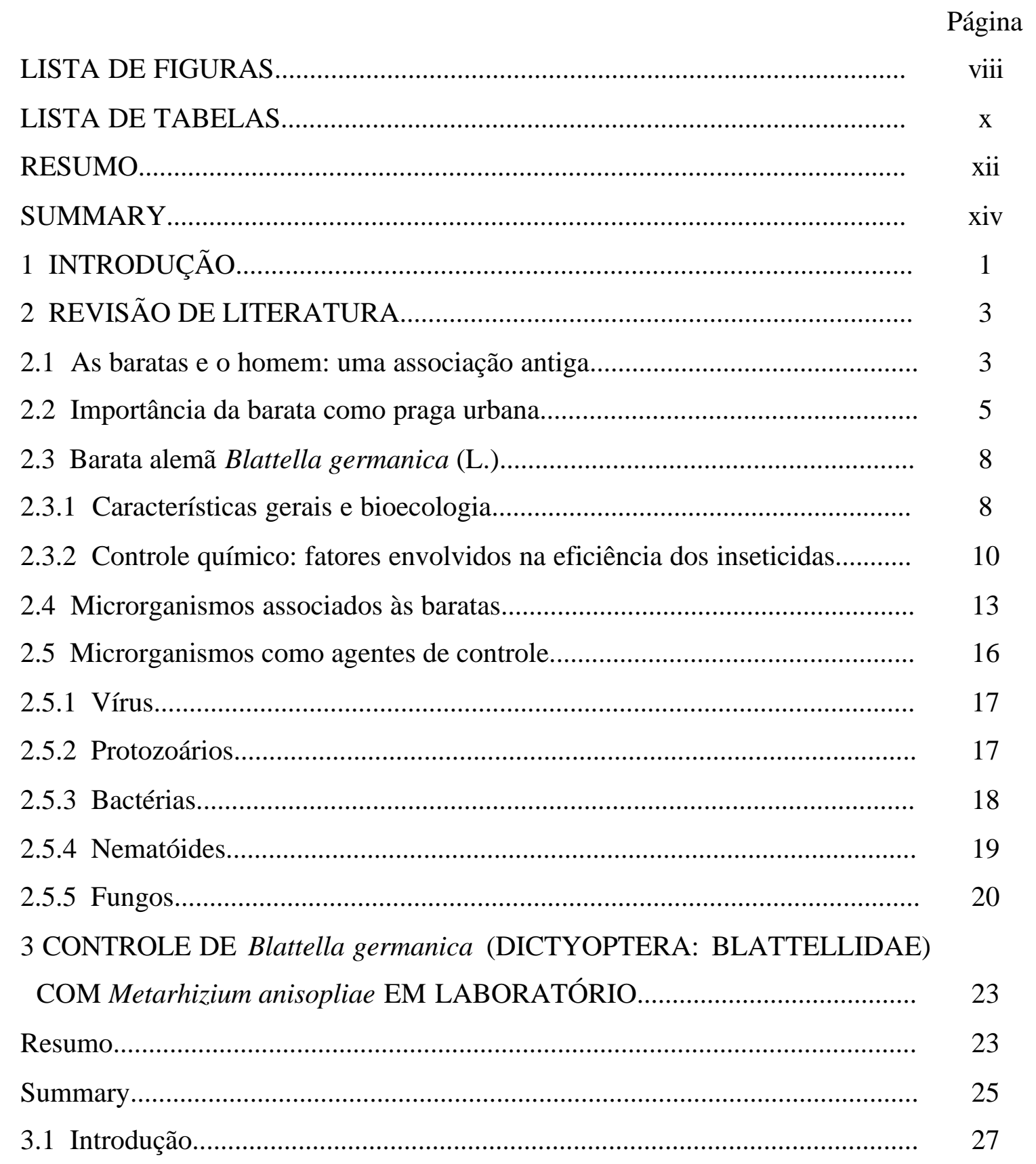


3.2 Material e Métodos.................................................................................... 28

3.2.1 Criação de Blattella germanica em laboratório........................................... 28

3.2.2 Produção do inóculo do fungo Metarhizium anisopliae (ESALQ-1037).... 28

3.2.3 Estimativa da dose-resposta de Metarhizium anisopliae (ESALQ-1037) para Blattella germanica............................................................................ 29

3.2.4 Avaliação da infectividade de Metarhizium anisopliae (ESALQ-1037)..... 30

3.2.5 Atividade de conídios de Metarhizium anisopliae (ESALQ-1037) nos sistemas respiratório e digestivo de Blattella germanica.................................... 32

3.3 Resultados e Discussão............................................................................. 33

3.3.1 Estimativa da dose-resposta de Metarhizium anisopliae (ESALQ-1037) para Blattella germanica............................................................................ 33

3.3.2 Avaliação da infectividade de Metarhizium anisopliae (ESALQ-1037)...... 37

3.4 Conclusões......................................................................................... 43

4 EFEITO DE ISCAS ATRATIVAS FORMULADAS COM TRIFLUMURON E PYRIPROXIFEN SOBRE NINFAS E ADULTOS DE Blattella germanica (DICTYOPTERA: BLATTELLIDAE).......................................................... 45

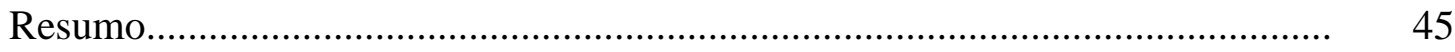

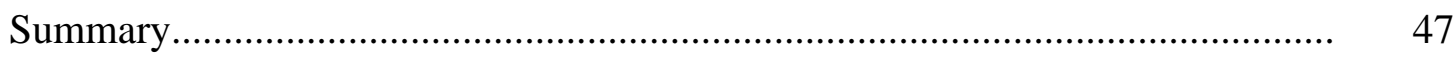

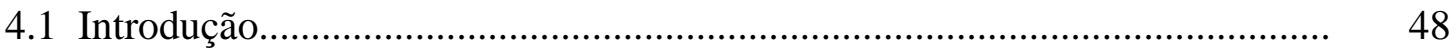

4.2 Material e Métodos................................................................................ 49

4.2.1 Eficiência dos inseticidas triflumuron e pyriproxifen sobre ninfas de Blattella germanica ...................................................................................... 49

4.2.2 Efeitos subletais dos inseticidas triflumuron e pyriproxifen......................... $\quad 50$

4.3 Resultados e Discussão............................................................................. 52

4.3.1 Eficiência dos inseticidas triflumuron e pyriproxifen sobre ninfas de

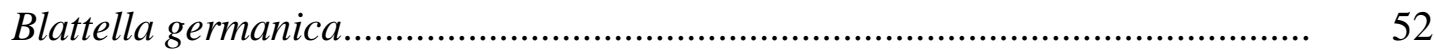

4.3.2 Efeitos subletais dos inseticidas triflumuron e pyriproxifen......................... 56

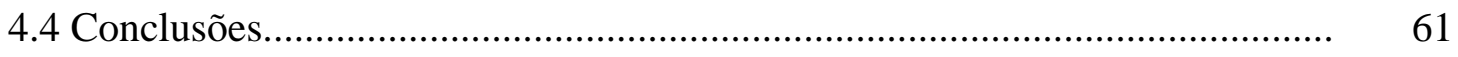

5 ASSOCIAÇÃO DE Metarhizium anisopliae COM OS INSETICIDAS TRIFLUMURON E PYRIPROXIFEN NO CONTROLE DE COLÔNIAS DE 


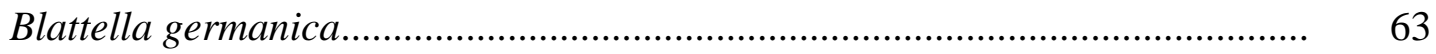

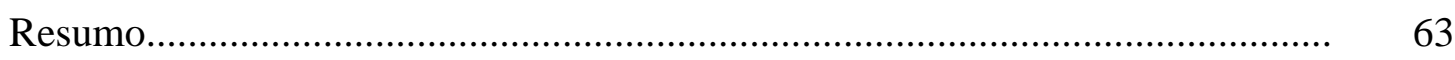

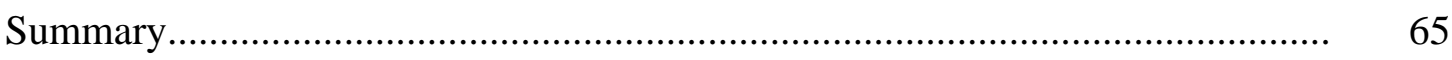

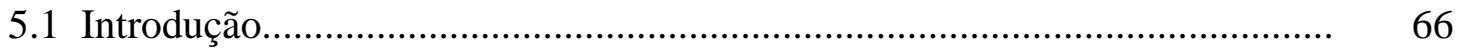

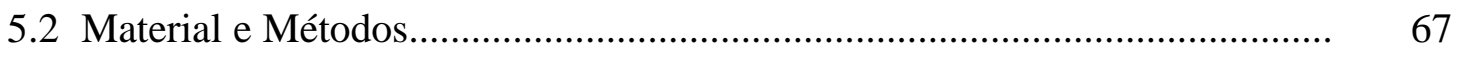

5.2.1 Avaliação da repelência de conídios de Metarhizium anisopliae (ESALQ1037) e da formulação pó seco para Blattella germanica..................................... 67

5.2.2 Compatibilidade "in vitro" dos inseticidas triflumuron e pyriproxifen com Metarhizium anisopliae (ESALQ-1037)......................................................... 69

5.2.3 Eficácia de Metarhizium anisopliae (ESALQ-1037) e dos inseticidas triflumuron e pyriproxifen sobre colônias de Blattella germanica em laboratório.

5.2.4 Avaliação da câmara de infecção Myco-IRC no controle de uma colônia de Blattella germanica em campo...................................................................... 71

5.3 Resultados e Discussão.............................................................................. 74

5.3.1 Avaliação da repelência de conídios de Metarhizium anisopliae (ESALQ1037) e da formulação pó seco para Blattella germanica...................................... 74

5.3.2 Compatibilidade "in vitro" dos inseticidas triflumuron e pyriproxifen ao fungo Metarhizium anisopliae (ESALQ-1037)................................................. 76

5.3.3 Eficácia de Metarhizium anisopliae (ESALQ-1037) e dos inseticidas triflumuron e pyriproxifen sobre colônias de Blattella germanica em laboratório.

5.3.4 Avaliação da câmara de infecção Myco-IRC no controle de Blattella germanica em campo..................................................................................... 81

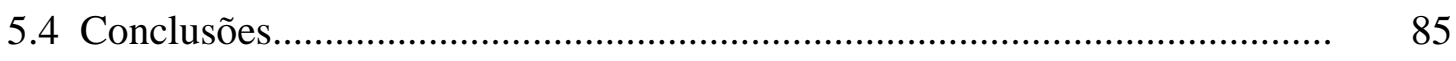

6 EFEITO DO PARASITISMO DE Gregarina sp. NA SUSCETIBILIDADE DE Blattella germanica (DICTYOPTERA: BLATTELLIDAE) AO FUNGO Metarhizium anisopliae E AO INSETICIDAS TRIFLUMURON..................... 86

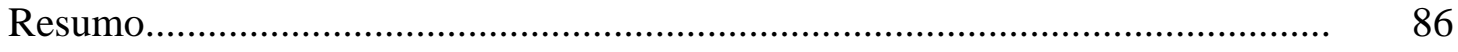

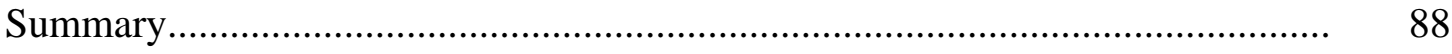




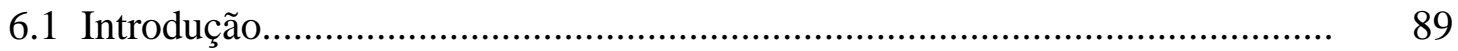

6.2 Material e Métodos.................................................................................... 90

6.2.1 Características e descrição da infecção......................................................... 90

6.2.2 Controle da doença em criações de laboratório............................................ 90

6.2.3 Influência do parasitismo na sobrevivência de adultos e ninfas................... 91

6.3 Resultados e Discussão.............................................................................. 92

6.4 Conclusões.......................................................................................... 99

7 CONCLUSÕES GERAIS................................................................. 100

REFERÊNCIAS BIBLIOGRÁFICAS................................................................ 102 


\section{LISTA DE FIGURAS}

Página

1 Desenvolvimento evolucionário das baratas (McKittrick, citado por Cornwell, 1968)

2 Formulações de inseticidas comercializadas internacionalmente para o controle de pragas urbanas segundo portal das indústrias Pest Control Technology (www.pctonline.com).

3 Curva dose-resposta expressa pela mortalidade de ninfas e adultos de Blattella germanica 15 dias após a aplicação de Metarhizium anisopliae em laboratório. Reta $=$ valores de probit calculado; pontos $=$ valores de probit observados.

4. Mortalidade de adultos de Blattella germanica expostos à isca contaminada com Metarhizium anisopliae (ESALQ1037) em diferentes concentrações........

5 Mortalidade de adultos de Blattella germanica expostos à superfície contaminada com Metarhizium anisopliae (ESALQ1037) em diferentes concentrações

6 Mortalidade de ninfas de Blattella germanica expostos à superfície contaminada com Metarhizium anisopliae (ESALQ1037) em diferentes concentrações

7 Conídios inviáveis de Metarhizium anisopliae observados na ampola retal de Blattella germanica após 48 horas da alimentação em iscas contaminadas.......

8 Curva concentração-resposta expressa pela mortalidade de ninfas de Blattella germanica 15 dias após a alimentação em iscas contaminadas com o inseticida triflumuron. Reta $=$ valores de probit calculado; pontos $=$ valores de probit observados. 
9 Curva concentração-resposta expressa pela mortalidade de ninfas de Blattella germanica 15 dias após a alimentação em iscas contaminadas com o inseticida pyriproxifen. Reta $=$ valores de probit calculado; pontos $=$ valores de probit observados.

10 Ninfas de Blattella germanica com sintomas de contaminação pelos inseticidas triflumuron $1 \%$ (A) e pyriproxifen $1 \%$ (B)

11 Porcentagem de mortalidade de ninfas, de emergência e de deformação de adultos de Blattella germanica 25 dias após a alimentação em iscas contaminadas com os inseticidas triflumuron (1\%) e pyriproxifen $(1 \%)$..

12 Número de ootecas e abortos observados por colônia e número de ninfas de Blattella germanica produzidas por ooteca, 25 dias após a alimentação em iscas contaminadas com os inseticidas triflumuron (1\%) e pyriproxifen $(1 \%)$...

13 Ootecas mal formadas e inviáveis (aborto) de Blattella germanica 25 dias após a alimentação de fêmeas virgens em isca contaminada com pyriproxifen $(1 \%)$

14 Modelo esquemático da câmara de infecção Myco IRC utilizada no teste de controle de Blattella germanica em campo.

15 Composição populacional (\%) da colônia de Blattella germanica no tratamento testemunha após 140 dias (Piracicaba, SP, 28/02/2004).....

16 A) trofozoítos desenvolvidos - epemerito (Ep), protomerito (Pro), deutomerito (Deu); B) gamontes (G) no trato digestivo; C) esporoducto contendo oocistos (Oc); D) gametocistos (Gam).

17 Mortalidade de adultos de Blattella germanica infectados e não infectados por Gregarina sp. submetidos ao tratamento com o fungo Metarhizium anisopliae $\left(5 \times 10^{5}\right.$ conídios/inseto).

18 Mortalidade de ninfas de Blattella germanica infectadas e não infectadas por Gregarina sp. alimentadas com o inseticida triflumuron (1\% i.a. no alimento)... 


\section{LISTA DE TABELAS}

Página

1 Microrganismos patogênicos ao homem que foram isolados de baratas coletadas em campo (adaptado de Brenner (1995))

2 Mortalidade média de ninfas e adultos de Blattella germanica expostos à isca contaminada com Metarhizium anisopliae (ESALQ1037) em diferentes concentrações

3 Mortalidade média de ninfas e adultos de Blattella germanica expostos à superfície contaminada com Metarhizium anisopliae (ESALQ1037).....

4 Porcentagem de mortalidade de ninfas, emergência e deformação de adultos de Blattella germanica submetidos ao tratamento com os inseticidas triflumuron e pyriproxifen.

5 Número de ootecas formadas, de abortos e de ninfas por ooteca para fêmeas virgens de Blattella germanica submetidas ao tratamento com os inseticidas triflumuron e pyriproxifen.

6 Consumo de alimento (mg) por ninfas e adultos de Blattella germanica submetidos ao teste de livre escolha para superfícies tratadas com Metarhizium anisopliae

7 Toxicidade dos inseticidas triflumuron e pyriproxifen para o fungo Metarhizium anisopliae (ESALQ-1037).

8 Efeito do fungo Metarhizium anisopliae e dos inseticidas triflumuron e pyriproxifen sobre colônias de Blattella germanica em laboratório

9 População de Blattella germanica capturada em um período de 72 horas por meio de armadilhas adesivas em colônias de campo (Piracicaba, SP, $13 / 10 / 2003$ a 28/02/2004) 
10 Valores de tempo letal $\left(\mathrm{TL}_{25}\right)$ de adultos de Blattella germanica infectados e não infectados por Gregarina sp. submetidos ao tratamento com o fungo Metarhizium anisopliae $\left(5 \times 10^{5}\right.$ conídios/inseto).

11 Valores de tempo letal $\left(\mathrm{TL}_{25}\right)$ de ninfas de Blattella germanica infectadas e não infectadas por Gregarina sp. alimentadas com o inseticida triflumuron (1\% i.a. no alimento) 


\title{
CONTROLE DE Blattella germanica (L.) COM Metarhizium anisopliae E INSETICIDAS REGULADORES DE CRESCIMENTO
}

\author{
Autor: ROGÉRIO BIAGGIONI LOPES \\ Orientador: Prof Dr. SÉRGIO BATISTA ALVES
}

\section{RESUMO}

Avaliou-se o efeito de Metarhizium anisopliae e dos inseticidas triflumuron e pyriproxifen para adultos e ninfas de Blattella germanica, e a eficiência da associação desses agentes no controle de colônias da praga. Doses elevadas do patógeno ocasionaram altos índices de mortalidade de adultos e ninfas. Não foi observada mortalidade significativa para insetos que se alimentaram de iscas contaminadas com o patógeno. Adultos e ninfas expostos à superfície contaminada com o fungo na formulação pó (5\%) apresentaram mortalidade de 93,7\% e 82,3\% após 9 dias da aplicação, respectivamente. As $\mathrm{CL}_{25}$ para ninfas tratadas com triflumuron e pyriproxifen foram de $0,19 \%$ e $0,45 \%$ de ingrediente ativo, respectivamente, para um período de alimentação de 72 horas na isca contaminada. Os inseticidas afetaram a produção de ootecas viáveis e o número de ninfas produzidas por ooteca. Após 60 dias, colônias de laboratório não tratadas apresentaram 6,55 vezes mais insetos em relação à população inicial, com uma média de 233,9 insetos. As colônias apresentaram crescimento menor quando submetidas aos inseticidas triflumuron e pyriproxifen, com 60,8 e 81 insetos em média, respectivamente. Os melhores resultados foram obtidos nos tratamentos em que os inseticidas foram associados ao patógeno, resultando populações de 41,8 e 57,7 insetos para triflumuron $+M$. anisolpiae e pyriproxifen $+M$. anisopliae, 
respectivamente. Duas aplicações associando-se o patógeno aos inseticidas na mesma isca atrativa, em uma câmara de infecção, controlou totalmente uma população em campo. Insetos da criação infectados por Gregarina sp. mostraram-se mais sensíveis quando expostos a $M$. anisopliae e a triflumuron em relação a insetos sadios. Estudos mais detalhados sobre como os inseticidas podem interferir no processo de doença casusada pelo fungo no inseto, além de aspectos relacionados à formulação do micoinseticida e da sua contribuição na mortalidade de populações de $B$. germanica em campo são ainda necessários. 


\title{
CONTROL OF THE GERMAN COCKROACH Blattella germanica WITH Metarhizium anisopliae AND INSECT GROWTH REGULATORS
}

\author{
Author: ROGÉRIO BIAGGIONI LOPES \\ Adviser: Prof Dr. SÉRGIO BATISTA ALVES
}

SUMMARY

It was evaluated the effect of Metarhizium anisopliae and the insect growth regulators triflumuron and pyriproxifen for adults and nymphs of the German cockroach Blattella germanica, and the efficacy of its association in the control of this urban pest. High doses of the pathogen caused high mortality of adults and nymphs. There was no mortality of B. germanica nymphs exposed for 72 hours to the food contaminated with M. anisopliae. The mortality of adults and nymphs was of $93.7 \%$ and $82.3 \%$, respectively, when exposed to a surface that had been contaminated with the fungus formulation (5\%), as early as 9 days after the application. The $\mathrm{LC}_{25}$ for nymphs exposed for a 72-hour period to the triflumuron-bait was $0.19 \%$ (active ingredient) and for pyriproxifen-baits $0.45 \%$, after 15 -day period. Both inseticides decreased the production of viable oothecae and the number of nymphs in this cases. Untreated colonies presented 6.55 fold in the number of insects after a 60-day period, with 233.9 average insects per colony. The colonies exposed to triflumuron and pyriproxifen had an average of 60.8 and 81 insects, respectively. The insecticides and fungus association presented populations of 41.8 and 57.7 insects for triflumuron $+M$. anisolpiae and pyriproxifen + M. anisopliae, respectively. Two applications of the association of $M$. anisolpiae and 
triflumuron+pyriproxifen-bait, in an infection chamber, eliminated a cockroach colony in the field. Gregarine-infected insects were more susceptible than healthy ones when treated with the entomopathogenic fungus $M$. anisopliae and the insect growth regulator triflumuron. More detailed studies on how the insecticides could interfere in the disease process caused by $M$. anisopliae, and aspects related to the fungus formulation and its contribution to the mortality of German cockroach field populations are still necessary. 


\section{INTRODUÇÃO}

A associação de alguns insetos e ácaros ao ser humano ocorreu, provavelmente, no início da evolução do homem primitivo em uma sociedade urbana. $\mathrm{O}$ ancestral do homem atual, Homo erectus, que aprimorou a capacidade de busca de alimento através da arte da caça após a extinção dos hominídios vegetarianos Austalopithecus, viveu a mais de um milhão de anos. O desenvolvimento desse ancestral resultou em uma espécie de homem com o cérebro maior, Homo sapiens, que foi capaz de se adaptar a diferentes ambientes, das regiões tropicais quentes ao gelo dos pólos.

Inicialmente, grupos nômades acompanhavam a abundância sazonal de plantas e animais de determinada região. Contudo, alguns grupos estabeleceram em pequenas vilas por longos períodos, por meio do cultivo primitivo de plantas

selecionadas. O passo seguinte no desenvolvimento da agricultura atual inclui o aperfeiçoamento de técnicas de criação de animais, cultivo de vegetais e armazenamento do alimento. Desta forma, a associação de artrópodes ao ser humano está diretamente relacionada com a grande habilidade desses organismos em se adaptarem às condições únicas desse novo ambiente e, principalmente, utilizarem os recursos alimentares explorados pelo homem.

O aumento da população mundial e dos centros urbanos, causado pela migração descontrolada de pessoas do meio rural para cidades, foi um fenômeno marcante durante o século XX. A concentração da população e a forma desorganizada de ocupação desses centros gerou a sociedade humana urbanizada, com características e hábitos peculiares. No Brasil, segundo o censo demográfico do IBGE (Instituto Brasileiro de Geografia e Estatística), no ano de 2000 apenas $23 \%$ da população nacional residia no meio rural. $\mathrm{O}$ adensamento nas cidades é mais evidente em algumas 
regiões do país, como no Sudeste, em que a população urbana chegou a 89,5\%, sendo no estado de São Paulo ainda maior, em torno de $93 \%$.

Os problemas advindos da urbanização descontrolada nas últimas décadas incluem, entre outros, o superpovoamento de determinadas áreas, a redução das condições sanitárias e o aumento da poluição do ar e da água, o que também favorece o desenvolvimento populacional de insetos e ácaros de importância médica associados ao homem. Esses artrópodes fizeram, com sucesso, a transição do habitat natural para o ambiente urbano. Dentre os ácaros destacam-se as sarnas e carrapatos de vertebrados e espécies alergênicas que se desenvolvem em alimentos armazenados e na poeira domiciliar. Em relação aos insetos destacam-se as pulgas, traças, baratas, cupins, formigas, moscas e mosquitos, muitos destes transmissores ou vetores de importantes patógenos do homem e de animais domésticos.

As baratas, em especial Blattella germanica, são de grande importância médica, por estarem simultaneamente associadas ao ambiente de vida do homem e a locais contaminados por microrganismos patogênicos ao homem e outros animais. Esse importante fato, além da repulsa causada pelas baratas, torna seu controle inevitável e desejável.

O uso de inseticidas químicos em ambientes domiciliares e em locais de armazenamento e manipulação de alimentos, principal prática de controle, pode levar à contaminação do homem e dos animais domésticos. Estratégias biológicas de controle das baratas, que incluem o emprego de fungos entomopatogênicos, podem reduzir esses riscos e proporcionar um efeito mais duradouro. Certamente, fatores econômicos e sociais ligados a cada povo ou país contribuem para a maior ou menor infestação de baratas no meio doméstico. Apesar das melhorias para o cidadão do meio urbano, proporcionado pelos governantes nas grandes cidades, a educação e a consciência das pessoas são fatores que estão diretamente relacionados com a qualidade de vida nos centro urbanos. O objetivo do presente estudo foi o de avaliar o potencial do fungo Metarhizium anisopliae associado aos inseticidas triflumuron e pyriproxifen no controle de populações de B. germanica. 


\section{REVISÃO DE LITERATURA}

\subsection{As baratas e o homem: uma associação antiga}

As baratas são, provavelmente, os mais antigos e importantes insetos associados ao ser humano. Pertencem a ordem Dictyoptera, também chamada de Blattodea, e permaneceram basicamente inalteradas em relação aos hábitos e forma corpórea nos últimos 300 milhões de anos. Fósseis de baratas são conhecidos da era Paleozóica, em rochas do período Carbonífero, época na história geológica com condições favoráveis para o desenvolvimento de uma flora abundante (Cornwell, 1968; Robinson, 1996).

As baratas mais primitivas estão contidas nas famílias Polyphagidae e Cryptocercidae, sendo que nessa última incluem espécies que se alimentam de madeira, semelhante aos térmitas ou cupins. De acordo com Imms (1931), os cupins originaramse de um antepassado comum às baratas e posteriormente desenvolveram-se em uma complexa sociedade organizada. Fósseis indicam que o cupim Mastotermes darwiniensis Frogg, possuía a estrutura das asas semelhante às das baratas, e também colocavam os ovos em massa como as ootecas. A figura 1 ilustra o desenvolvimento evolucionário das baratas, subordem Blattaria, de acordo com McKittrick (citado por Cornwell, 1968).

Durante os primeiros estágios de sua evolução as baratas se adaptaram ao escuro e às condições de alta umidade do rico solo orgânico das florestas tropicais. Dessa forma, das 3.500 espécies descritas em todo o mundo a grande maioria é silvestre, apenas 1\% dessas possuem hábito domiciliar (Cornwell, 1968; Mariconi, 1999). O hábito onívoro e noturno proporciona às baratas um abundante suprimento alimentar e maior proteção contra predadores. Dessa forma, o ambiente doméstico, especialmente os 
grandes centros urbanos, leva ao desenvolvimento de grandes populações de baratas, agravando os problemas relacionados à elas. Até em tribos indígenas na Amazônia a incidência do inseto é de tal gravidade que obriga as aldeias a mudarem de local ou a queimarem suas casas periodicamente (Posey, 1986).

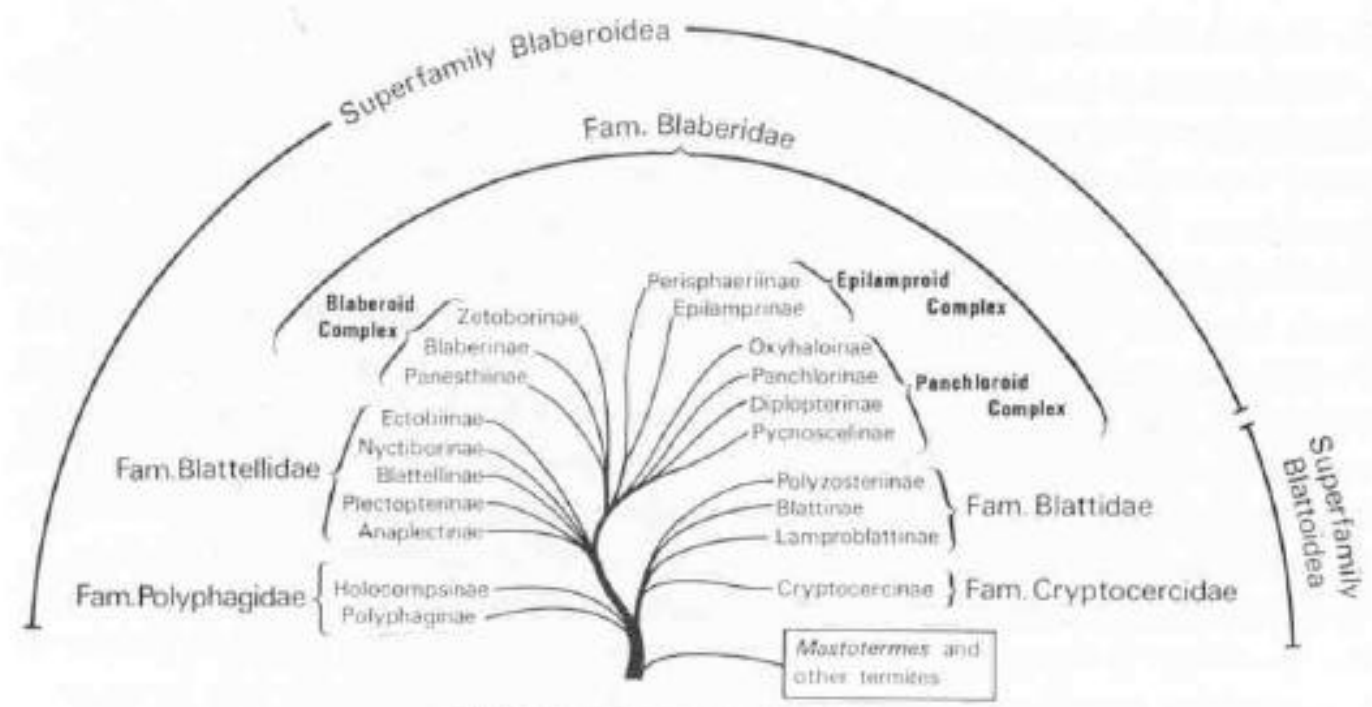

THE SUB-ORDER BLATTARIA

Figura 1- Desenvolvimento evolucionário das baratas (McKittrick, citado por Cornwell, 1968)

A maioria das espécies associadas aos seres humanos são, provavelmente, originárias de regiões tropicais e subtropicais, explorando inicialmente os refugos orgânicos do homem primitivo. A proteção e as boas condições de temperatura e umidade proporcionadas pelo ambiente domiciliar e, principalmente, o abundante suprimento alimentar durante todo o ano permitiu a evolução dessas espécies como pragas urbanas. 


\subsection{Importância da barata como praga urbana}

A grande importância das baratas como praga domiciliar está tradicionalmente ligada a sua capacidade de disseminar microrganismos nocivos ao homem e outros animais. Adultos e ninfas podem carregar vírus, dezenas de bactérias, fungos e protozoários. Também atuam como hospedeiros intermediários de muitos helmintos do homem e animais domésticos (Cornwell, 1968; Robinson, 1996; Mariconi, 1999). Entretanto, algumas questões ainda permanecem: com que freqüência as baratas estão envolvidas na transmissão de doenças ao homem? Elas sempre são responsáveis pelo desencadeamento dessas doenças? A pesquisa na área médica e a busca de respostas para tais perguntas são estimuladas pela íntima associação das baratas com o alimento humano ou locais de manipulação e armazenamento de alimentos, e com sua freqüente presença em locais de lixo orgânico, no lixo hospitalar, em dejetos humanos ou no esgoto. As baratas se alimentam indiscriminadamente de fezes e urina do homem ou animais, tendo acesso a uma grande variedade de microrganismos, e do alimento a ser consumido pelas pessoas.

As baratas podem ocasionar ainda um dano difícil de ser avaliado mas muito importante, que é distribuição de resíduos químicos tóxicos no ambiente. Inseticidas químicos utilizados no controle dos insetos ou componentes tóxicos de resíduos industriais podem causar doenças ao homem, que se contamina via alimento ou água, e não foram avaliados ainda pela sociedade.

Além do possível papel das baratas na transmissão de microrganismos patogênicos e substâncias tóxicas, a ocorrência desses insetos em convívio com o homem pode causar diversas respostas alérgicas em indivíduos sensíveis. A exposição à substâncias alergênicas contidas em fezes e fragmentos do tegumento desses insetos causam irritações na pele e alergias respiratórias em algumas pessoas. A intensidade das reações depende de uma série de fatores, que incluem, entre outros, a via, intensidade e duração da exposição e a capacidade de resposta imunológica do indivíduo (Wikel, 1982). Writz (1984) cita alguns estudos sobre reações alérgicas causadas por baratas domésticas, entre elas Blattella germanica e Periplaneta americana, que incluem 
dermatite, rinite, bronquite, asma e até choque anafilático. O tratamento de pessoas alérgicas exige constante acompanhamento médico e inclui o uso de medicamentos que controlam os sintomas (anti-histamínicos, broncodilatadores e corticóides) ou vacinas hipossensibilizantes.

A alergia é uma resposta excessiva do sistema imunológico do homem a uma substância estranha ou antígeno, que estimula a produção de anticorpos. Esse anticorpo está presente em pequenas quantidades em indivíduos normais. Já em pessoas alérgicas, o anticorpo é produzido em grandes quantidades pelo organismo e nessas condições gera uma reação adversa. Em pacientes asmáticos, a função pulmonar durante um ataque de asma é afetada, em casos sérios reduz-se a capacidade de ventilação e pode até causar a morte. Logicamente, os ataques alérgicos geram um custo considerável, que envolvem cuidados médicos, internações, medicamentos e perda de dias de trabalho por licença médica (Carrer et al., 2001).

Segundo Hahnstadt (1999), medidas para diminuir a exposição de pessoas sensíveis aos alérgenos das baratas ainda não estão bem esclarecidas. Sabe-se contudo, que pessoas que vivem em condições inadequadas de higiene, onde as populações de baratas e o acúmulo de poeira são maiores, mostram um grau mais elevado de sensibilidade aos alérgenos (Huss et al., 2001; Borges et al., 2003). A forma mais eficaz é a redução da infestação dos insetos no ambiente doméstico por medidas que incluem, além da desinsetização, modificações internas que evitem o acúmulo de poeira e fontes de alimento e água para as baratas.

Existem, contudo, outras razões, além da importância médica das baratas, que a elevam a um status de praga urbana, como o estigma social que envolve a presença desses insetos nas residências. Na sociedade atual, a barata frequentemente indica condições sanitárias precárias e desleixo nos cuidados com a casa. Ainda, para algumas pessoas, a presença de insetos a sua volta conduzem a um irracional e inexplicável pavor ou medo, a entomofobia. Em casos extremos, a fobia por insetos pode levar a mudanças significativas no modo de viver da pessoa e resultar em um constante sofrimento. A entomofobia é um dos medos da sociedade humana, que incluem, entre outros, o medo de lugares fechados, de altura ou de aviões. Esse pavor de algumas pessoas por insetos, 
em especial as baratas, com causas obviamente psicológicas, provavelmente, está ligado ao seu aspecto e comportamento característicos. Antenas longas em constante movimento, corridas curtas e rápidas, o odor característico e o aspecto úmido e liso das baratas, certamente causam repulsa para a maioria das pessoas.

Independente da forma em que as baratas atuam no nosso ambiente, seja pela transmissão de doenças, alergias ou pela sua simples e indesejável presença, seu controle é uma necessidade, e o custo elevado. No Brasil, não existem referências ou estudos dos gastos com o controle de baratas, entretanto, estimativas nos Estados Unidos confirmam a importância econômica da praga (Brenner, 1995). De acordo com Nolasco (1999), a indústria de pesticidas nos Estados Unidos chega a gastar anualmente cerca de US\$1,5 bilhão em produtos para o controle de baratas. Por outro lado, alguns pesquisadores consideram que o dano causado pela presença das baratas no meio urbano é de difícil determinação, ou até impossível de se calcular (Peterson \& Shurdut, 1999). Isso porque não existe uma forma real de atribuir valores materiais ou em dinheiro para a injúria causada à vida de uma pessoa.

Apesar da grande importância médica das baratas como pragas urbanas, da repugnância por elas causada e do custo envolvido em seu controle, aspectos benéficos podem ainda ser citados. Algumas espécies são usadas com propósitos médicos no tratamento de doenças e também na culinária asiática, ou ainda servem de inspiração na literatura e no cinema (Appel, 1995; Robinson, 1996). O emprego de insetos na cura de doenças é também amplamente difundido entre grupos indígenas. Tribos indígenas da Amazônia utilizam-se das baratas para tratamento do alcoolismo, colite, constipação e dor de dente, entre outras (Posey, 1986).

As três espécies de baratas domissanitárias mais importantes são B. germanica (barata alemã), P. americana (barata americana) e Blatta orientalis (barata oriental), essa última mais comum em regiões de clima temperado (Mariconi, 1999). Dentre essas, a barata alemã é a que vem causando maiores preocupações e prejuízos em países tropicais e subtropicais como o Brasil, desenvolvendo altas populações em restaurantes, residências, hospitais e locais de armazenamento de alimentos. 


\subsection{Barata alemã Blattella germanica (L.)}

\subsubsection{Características gerais e bioecologia}

As baratas do gênero Blattella pertencem a família Blattellidae, sendo $B$. germanica, descrita por Linnaeus em 1767, uma das espécie mais importante no meio urbano e amplamente distribuída no mundo todo. São de tamanho reduzido, de 10$14 \mathrm{~mm}$ de comprimento, e coloração marrom. Como a maioria das baratas, possui o corpo ovalado e achatado dorso-ventralmente, pronoto recobrindo a cabeça, longas antenas filiformes e mandíbulas bem desenvolvidas. As pernas são longas, finas e com espinhos, bem adaptadas para corrida, já que essa espécie tem uma pequena capacidade de vôo, apesar da presença das asas.

A barata alemã, como outros insetos de desenvolvimento incompleto, passa pelos estágios de ovo, ninfa e adulto, e completa o ciclo de ovo a adulto em

aproximadamente 100 dias, sob condições favoráveis do ambiente. A reprodução é sexuada e os ovos, que ficam inicialmente alinhados e retidos na porção final do abdome da fêmea, recebem uma proteção produzida por glândulas secretoras, formando uma cápsula compartimentalizada, a ooteca. O número de ovos por ooteca pode variar de 30 a 40 para diferentes populações, dependendo também das condições do ambiente e da idade da fêmea. A ooteca permanece presa ao corpo da fêmea até a eclosão das ninfas, ou é liberada pouco antes, e o período embrionário varia de 20 a 30 dias.

A espécie passa, mais freqüentemente, por 5 ou 6 ecdises na fase imatura. $\mathrm{O}$ número de ecdises sofridas pelo inseto é determinado no terceiro ínstar, onde ninfas relativamente pequenas têm um ínstar a mais, resultando em adultos com tamanho normal. A fase imatura tem duração de, aproximadamente, 50-60 dias em condições normais e é grandemente afetada pela variação da temperatura.

Os adultos que emergem na última ecdise são alados com claro dimorfismo entre machos e fêmeas. Os machos são de coloração marrom-amarelo e o abdome longo e esbelto, freqüentemente estendendo-se além das asas. As fêmeas não possuem estilos, são um pouco mais escuras e as asas recobrem totalmente o abdome. $\mathrm{O}$ acasalamento 
ocorre uma semana após a emergência dos adultos. As fêmeas vivem mais do que os machos, de forma geral, uma variação de 140 a 280 dias para fêmeas e de 90 a 140 dias para machos (Cornwell, 1968; Ross \& Mullins, 1995).

São insetos de hábito gregário, que vivem em conjunto, contudo, não possuem características típicas de outros grupos sociais como as abelhas e cupins. Desse modo, não estão divididos em castas e também não apresentam divisão de tarefas. $O$ comportamento de agregação das baratas é regido por feromônios que encontram-se presentes na cutícula do inseto (Rivault et al., 1998) ou em suas fezes (Ishii \& Kuwahara, 1967; Sakuma \& Fukami, 1990).

O grande sucesso da barata alemã como praga urbana deve-se, principalmente, às características de seu ciclo de vida e de como a espécie se adaptou ao ambiente e hábitos do homem. Em relação aos aspectos biológicos, destaca-se o grande número de descendentes produzidos e a proteção constante dos ovos, proporcionada pela própria ooteca e pela retenção da mesma pela fêmea no período crítico do desenvolvimento embrionário.

No que diz respeito à adaptação ao ser humano, características relacionadas à alimentação e ao comportamento dos insetos são importantes nessa evolução. O hábito onívoro da espécie, ou seja, a capacidade de alimentar-se em uma grande variedade de materiais e aproveitar determinados elementos essenciais, permite a rápida colonização de novos nichos. A associação das baratas com bactérias endosimbiontes, aparentemente fornece uma vantagem nutricional e metabólica para o inseto (Mullins \& Cochran, 1987).

Deve-se também considerar os hábitos noturnos das baratas domiciliares, abandonando seu esconderijo somente nesse período em busca de água e alimento, o que evita a ação de predadores e do homem. Baixas temperaturas e a falta de água e alimento são determinantes na colonização de novas áreas por B. germanica, contudo, adultos podem sobreviver por até uma semana sem água e comida. Pode-se dizer com certeza, que o bom entendimento dos aspectos biológicos e comportamentais do inseto é essencial na determinação das estratégias e dos produtos a serem utilizados no seu controle, buscando sempre uma alta eficiência, com segurança e baixos custos. 


\subsubsection{Controle químico: fatores envolvidos na eficiência dos inseticidas}

O uso de inseticidas químicos no controle de baratas, em especial $B$. germanica, consiste em uma prática, amplamente difundida no mercado domissanitário brasileiro. Atualmente, estão registrados no país dezenas de produtos para esse fim, sendo principalmente compostos dos grupos dos piretróides, organofosforados e carbamatos. A grande maioria dos inseticidas sintéticos convencionais disponíveis no mercado mundial são, basicamente, de ação neurotóxica. São altamente eficientes no controle de baratas quando bem aplicados, contudo, a eficiência desses produtos pode ser influenciada por vários fatores.

Pesquisas recentes realizadas junto aos profissionais controladores de pragas urbanas revelam algumas das principais características do mercado brasileiro na área. As baratas são responsáveis por um dos maiores índices de importância no faturamento das empresas (11\%) em comparação com outras pragas, sendo que essa porcentagem aumenta em regiões mais populosas das grandes cidades. A metodologia de aplicação mais utilizada para o controle de pragas em geral é a pulverização de piretróides (24\%), contudo, o uso de iscas vem crescendo e já ocupa o segundo método mais aplicado (Syngenta, 2001).

A consciência e os hábitos de higiene de cada pessoa estão diretamente relacionados com a maior infestação por baratas e, provavelmente, são importantes fatores que influenciam na eficiência das aplicações de inseticidas. Existe assim uma correlação positiva entre condições precárias de sanitização e o aumento populacional das baratas. Em condições sanitárias adequadas a eficiência no tratamento de áreas infestadas por B. germanica com alguns inseticidas é maior (Schal, 1988). Dessa forma, prevenir a colonização e o aumento da população do inseto em determinado local, seja impedindo fisicamente a invasão por ralos, esgotos e frestas, ou evitando seu acesso a fontes de água e alimento, auxiliam no seu controle. A avaliação correta da infestação de áreas onde serão realizadas as aplicações do produto químico, através de técnicas de monitoramento, pode também influenciar no bom controle ou na completa ineficiência do tratamento. 
Semelhante ao que ocorre com outros grupos de artrópodes pragas, agrícolas ou urbanas, onde o tratamento químico é necessário e constante, o desenvolvimento da resistência de baratas aos inseticidas vem sendo um dos grandes entraves no seu efetivo controle. Esse problema parece estar mais ligado à barata alemã, B. germanica, provavelmente pela sua maior importância como praga urbana e seu alto potencial reprodutivo, exigindo por consequiência a intensiva ou constante aplicação de inseticidas (Cochran, 1999). O histórico da resistência em baratas, em especial B. germanica, é amplamente discutido e documentado na literatura a partir da década de 50 (Cornwell, 1976). Nos últimos anos, a resistência de B. germanica a várias moléculas inseticidas vem sendo cada vez mais relatada. Até 1980 foram documentadas 504 espécies de insetos e ácaros resistentes a pelo menos uma classe de produto químico. $\mathrm{O}$ aumento dos casos, incluindo as baratas, ocorre sobretudo para os maiores grupos químicos da segunda geração de inseticidas, no caso organofosforados, carbamatos e piretróides (Georghiou \& Lagunes-Tejeda, 1991; Cochran, 1995). Entretanto, de acordo com Schal \& Hamilton (1990), apesar do problema da resistência em pragas urbanas estar sendo estudado de forma intensiva, essa informação não está sendo usada de forma eficaz em estratégias de manejo da praga. Os autores observam ainda que a prática usual no combate às populações resistentes é o aumento das doses e da freqüência de aplicação dos produtos, o que agrava o problema.

Outro grande problema relacionado à aplicação dos inseticidas químicos convencionais mais utilizados no mercado está justamente ligado ao seu modo de ação. Inseticidas neurotóxicos, como os organofosforados, carbamatos (inibidores da acetilcolinesterase) e piretróides (atuam na transmissão axônica), também agem sobre mamíferos. Em aplicações no ambiente urbano, sobretudo em residências, restaurantes, hospitais e locais de armazenamento de alimentos, a atenção com problemas de intoxicação de pessoas, incluindo aplicadores, e animais domésticos ou de alimentos deve ser redobrada (Wickham, 1995; Cochran, 1999). De acordo com uma lista de produtos divulgada em 2002 pelo portal internacional das indústrias de controle de pragas, Pest Control Technology, 52\% das formulações comercializadas para o controle de pragas urbanas são organofosforados, carbamatos ou piretróides, predominando o 
último grupo (Figura 2). Em função da preocupação com a segurança desses produtos e, principalmente, pelos problemas relacionados com o desenvolvimento de resistência, que nos últimos anos outros grupos de inseticidas vêm sendo estudados e, em alguns casos, utilizados no controle de baratas, entre eles produtos botânicos, a abamectina e a hydrametilona.

Os inseticidas reguladores de crescimento (IRC's) possuem toxicidade a mamíferos muito reduzida e também vem chamando a atenção de pesquisadores para seu uso no controle de pragas domissanitárias. Os IRC's são compostos que interferem no crescimento normal e na reprodução dos insetos, afetando o balanço de certos hormônios e enzimas ou influenciando em suas ações. A exposição a determinado IRC, normalmente não causa efeitos letais imediatos, mas induz anomalias que impedem a sobrevivência ou reprodução em momentos particulares da vida do inseto (Bennett \& Reid, 1995; Aguilera et al., 2001). Contudo, apenas $8 \%$ do total de formulações existentes no mercado são inseticidas reguladores de crescimento (Figura 2).

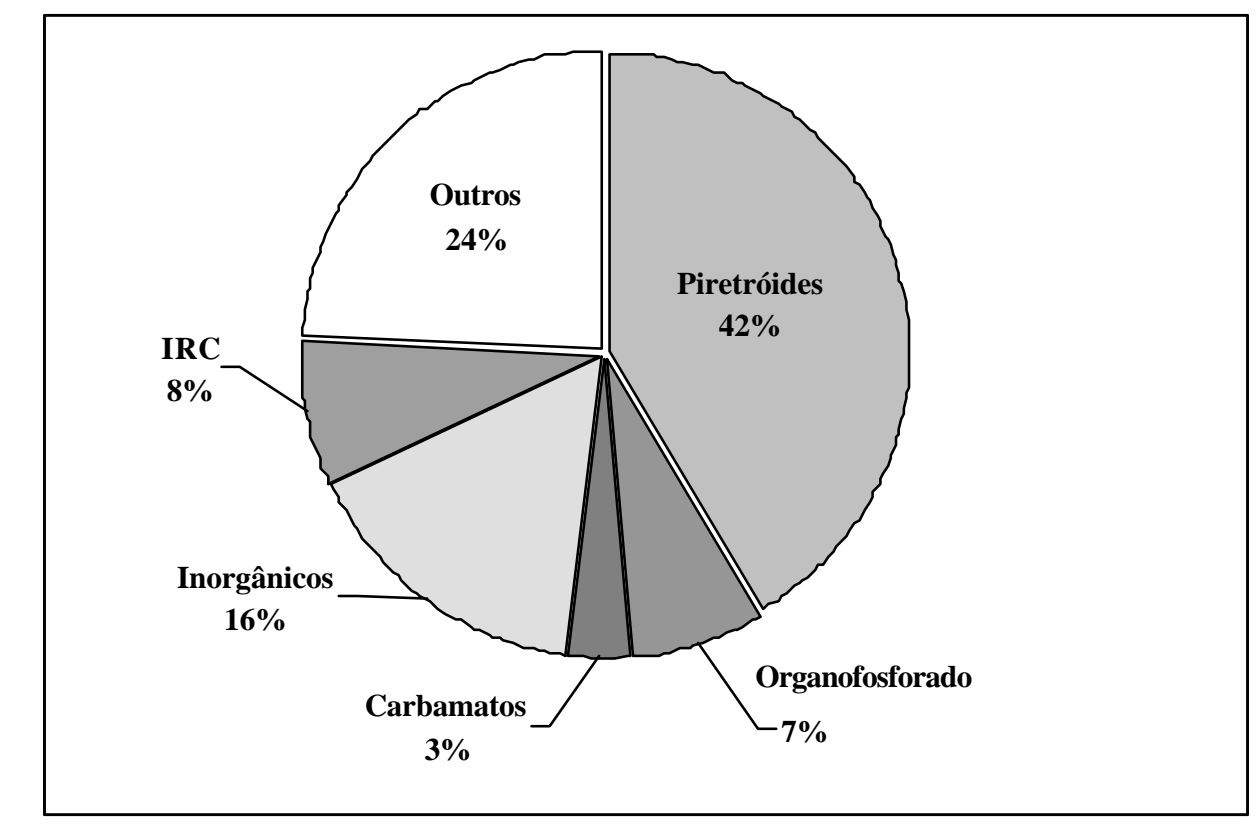

Figura 2- Formulações de inseticidas comercializadas internacionalmente para o controle de pragas urbanas segundo portal das indústrias Pest Control Technology (www.pctonline.com) 
Algumas características comportamentais das baratas favorecem a ação dos IRC's sobre uma população. O canibalismo pode ocorrer em B. germanica, especialmente na ausência de alimento, e provavelmente oferece uma vantagem adaptativa, permitindo o controle da densidade populacional e concentrando nutrientes essenciais em grupos menores (Ross \& Mullins, 1995). Esse comportamento, bem como a alimentação de ninfas recém eclodidas em pellets fecais da colônia para aquisição da microfauna intestinal e o contato constante entre insetos que permanecem agregados, é importante no "efeito dominó" ou mortalidade em cadeia do IRC (Gahlhoff Jr. et al., 1999; Kopanic \& Schal, 1999; Durier \& Rivault, 2000; Buczkowski \& Schal, 2001).

Diferentemente dos inseticidas convencionais, que são efetivos sobre todos os estágios de desenvolvimento do inseto e possuem efeito letal imediato, os IRC's são produtos de ação mais lenta, o que leva a uma certa dúvida em relação ao seu uso no controle de baratas. A maioria das pessoas, incluindo indústrias de serviço e pesquisadores, tem a dificuldade de visualizar o efeito do IRC no controle a longo prazo, o que, apesar da segurança, torna imprevisível o futuro desse grupo de inseticidas. Contudo, o uso planejado desses produtos em um programa de manejo da barata alemã, que envolva formas alternativas de controle, a adequada sanitização e a associação com produtos convencionais, pode conduzir a excelentes resultados e evitar os problemas observados no modo de controle atualmente realizado.

\subsection{Microrganismos associados às baratas}

Existem diferentes formas de associação de microrganismos às baratas, baseadas em interações simbióticas e/ou parasitárias. No primeiro caso, são correntes o comensalismo, quando microrganismos oportunistas saprófitas são simplesmente carregados pelo inseto, e o mutualismo, caracterizado pela coexistência das baratas e de endosimbiontes intestinais que atuam na digestão do alimento pelo inseto. No parasitismo destacam-se alguns microrganismos patogênicos, que desencadeiam um processo de doença e, na maioria dos casos, levam à morte do inseto, e que serão discutidos com mais detalhes posteriormente. 
A habilidade de digestão da celulose, muito comum em cupins, não é uma característica bem desenvolvida em baratas. Contudo, Cryptocercus punctulatus Scudder, uma espécie primitiva e sem asas, alimenta-se em madeira. Os microrganismos que ocorrem no intestino dessa barata são capazes de digerir a celulose, assim como nos cupins. Essa simbiose explica o comportamento sub-social de C. punctulatus, que precisa viver em conjunto para que ninfas recém eclodidas adquiram o protozoário dos pellets fecais de ninfas mais desenvolvidas. Doze gêneros, compreendendo 25 espécies de protozoários flagelados, estão associados à essa barata, destacando-se Trichonympha, que também ocorre em térmitas, e Barbulanympha (Cornwell, 1968). Bactérias endosimbiontes encontradas no tecido gorduroso dessa barata, como Blattabecterium, são também responsáveis pela conversão de alguns compostos em substâncias que possam ser aproveitadas (Clark \& Kambhampati, 2003). Dessa forma, além dos aspectos morfológicos já citados, o parentesco das baratas com os cupins pode também ser constatado pela ocorrência desses endosimbiontes nos dois grupos. Entretanto, a origem evolucionária dos endosimbiontes ainda não está claramente estabelecida e vem sendo amplamente discutida na literatura (Grandcolas \& Deleporte, 1996; Moran \& Telang, 1998).

Apesar de apenas um grupo pequeno de baratas possuir tal habilidade, a maioria das espécies apresentam bactérias intestinais que auxiliam na hidrólise de vários compostos, como já descrito anteriormente. Segundo Zurek \& Keddie (1996), a redução do número de bactérias anaeróbicas no trato digestivo de ninfas de $P$. americana, por meio do tratamento com antibiótico, afetou significativamente o ganho de peso e aumentou o tempo de desenvolvimento do inseto, quando comparadas com ninfas não tratadas.

Em função do hábito onívoro das baratas e das suas condições de vida, muitos microrganismos oportunistas podem associar-se externa ou internamente ao corpo do inseto e serem transportados para outros sítios. São principalmente fungos e bactérias de características saprofíticas ou decompositores que se associam às baratas por ocasião de sua alimentação em produtos já contaminados e, provavelmente, não afetam de forma negativa a vida do inseto (Cornwell, 1968). Dentro desse grupo destacam-se ainda 
microrganismos patogênicos aos animais e ao homem, contudo, a real importância médica das baratas, atuando como transmissores, permanece ainda como uma questão não totalmente esclarecida para muitos pesquisadores. De qualquer forma, a presença desses microrganismos associados às baratas é um fato incontestável e amplamente discutido na literatura (Schal \& Hamilton, 1990; Cochran, 1999). Brenner (1995) relaciona diversos microrganismos patogênicos ao ser humano associados à baratas coletadas em campo (Tabela 1.)

Tabela 1. Microrganismos patogênicos ao homem que foram isolados de baratas coletadas em campo (adaptado de Brenner (1995))

\begin{tabular}{ll}
\hline MICRORGANISMO & \multicolumn{1}{c}{ PATÓGENO } \\
\hline Bactérias & Alcaligenes faecalis, Bacillus spp., Campylobacter jejuni, \\
& Clostridium spp., Enterobacter aerogenes, Escherichia coli, \\
& Klebsiella pneumoniae, Mycobacterium leprae, Nocardia sp., \\
& Proteus spp., Pseudomonas aeruginosa, Salmonella spp., Serratia \\
& marcescens, Shigella dysenteriae, Staphylococcus aureus, \\
& Streptococcus spp., Vibrio spp., Yersinia pestis \\
Fungos & Alternaria sp., Aspergillus spp., Candida spp., Cephalosporium \\
& acremonium, Cladosporium sp., Fusarium sp., Geotrichum \\
Protozoários & candidum, Mucor sp. Penicillum, Rhizopus sp., Rhodotorula \\
Vírus & rubra, Trichoderma viride, Trichosporum cutaneum \\
Helmintos & Entamoeba histolytica, Giardia sp. \\
& Poliomyelitis \\
& Ancylostoma duodenale, Ascaris lumbricoides, Enterobius \\
& vermicularis, Hymenolopsis sp., Necator americanus, Trichuris \\
& trichuria
\end{tabular}

O fato das baratas estarem frequentemente associadas a possíveis fontes de microrganismos patogênicos ao homem, em função do próprio hábito do inseto, não deixa claramente caracterizado seu comportamento como vetor. O termo vetor é 
definido como algo que serve de veículo para uma agente patogênico ou parasita, e onde exista algum tipo de relação entre o microrganismo e seu hospedeiro intermediário. Nesse caso, observa-se um processo de coevolução, em que o patógeno depende de algum modo do vetor para sua disseminação ou sobrevivência. A discussão a respeito das baratas serem vetores de doenças para o homem ocorre justamente pelo fato dessa associação ser geralmente ocasional.

Contudo, em muitos casos essa relação entre inseto e microrganismos merece atenção e deve ser considerada. Kopanic Jr. et al. (1994), por exemplo, comprovaram a capacidade de baratas adquirir a bactéria Salmonella typhimurium em alimentos contaminados e transmiti-la para outras fontes de água e alimento. Pai et al. (2003) também comprovam o importante papel das baratas na disseminação mecânica de cistos de Entamoeba histolytica. Esse patógeno associa-se externa e internamente ao corpo de $P$. americana e B. germanica. Entre tantos outros casos, de acordo com especialistas, suspeitas recaem também sobre as baratas pelo possível papel delas na disseminação do vírus da Síndrome Respiratória Aguda Severa (SARS), uma doença que deixou em alerta o mundo todo no início de 2003 e causou a morte de dezenas de pessoas na Ásia.

\subsection{Microrganismos como agentes de controle}

O parasitismo de baratas por microrganismos é uma forma de associação que desperta grande interesse do meio científico na busca de agentes de controle biológico da praga. $\mathrm{O}$ controle microbiano de pragas tornou-se uma realidade nas últimas décadas e vem sendo aplicado com sucesso em vários segmentos da agricultura. Em relação às pragas urbanas, o desenvolvimento do controle microbiano e a utilização prática desse método são bem mais modestos. Um avanço maior tem sido observado em relação ao controle de mosquitos com bactérias do gênero Bacillus ou nematóides mermitídeos. A literatura sobre o potencial de microrganismos como agentes de controle de baratas não é muito vasta, contudo, são feitas referências aos principais grupos de patógenos de artrópodes. 


\subsubsection{Vírus}

Poucos vírus tem sido encontrados infectando baratas. De acordo com a lista de hospedeiros dos principais grupos de vírus entomopatogênicos citada por Evans \& Shapiro (1997), somente Densovirus (DNV) da família Parvoviridae infecta baratas. Contudo, Kleespies et al. (1999) investigando um novo iridovírus isolado de grilos e sua capacidade de infectar outros hospedeiros, observaram que ninfas de primeiro ínstar de $P$. americana, B. germanica e $B$. orientalis foram suscetíveis ao patógeno em condições de laboratório. Mais recentemente, Radek \& Fabel (2000) descreveram a ocorrência de um entomopoxivírus (EPV) causando infecções crônicas em B. germanica. Os insetos doentes apresentavam mobilidade reduzida e, possivelmente, a infecção levou a uma diminuição do crescimento populacional, sem entretanto causar altos índices de mortalidade.

\subsubsection{Protozoários}

Doenças causadas por protozoários têm um papel importante na regulação natural de populações de insetos pragas. Geralmente, são específicos e de ação lenta, na maioria das vezes produzindo infecções crônicas, e por essas características são comuns em criações de insetos (Alves \& Lecuona, 1998; Boucias \& Pendland, 1998).

Os eugragarinídeos, o maior grupo do filo Apicomplexa, são parasitos intestinais obrigatórios de uma série de invertebratos, incluindo os insetos (Levine, 1988a; Levine 1988b; Clopton, 2002). Em baratas, referências sobre a ocorrência de eugregarinídeos em criações de laboratório (Ball et al., 1995; Clopton, 1995), métodos de controle da doença em criações massais (Clopton \& Smith, 2002) e estudos de especificidade (Clopton \& Gold, 1996) são encontrados na literatura.

A ocorrência natural desses patógenos em ambientes urbanos também é comum em muitas espécies de baratas. Estudos conduzidos por Serra-Freire (1999) determinaram a diversidade parasitária de colônias de $P$. americana, sendo identificadas seis espécies de protozoários associadas a adultos e ninfas do inseto: Gregarina 
blattarum, Endamoeba blattae, Hexamita periplanetae, Lophomonas striata, Lophomonas balttarum e Nyctotherus ovalis, essa última dominante nas amostras. O autor observou ainda uma maior sensibilidade de baratas com elevado índice médio de parasitismo à inseticidas organofosforados. Para adultos e ninfas de $B$. germanica também coletadas em campo, Tsai \& Cahill (1970) identificaram sete espécies de protozoários, sendo Nephridiophaga blattellae, que parasita os túbulos de Malpighi do inseto, a mais prevalente. Apesar da ocorrência natural e dos benefícios que os protozoários possam oferecer, segundo Lacey et al (2001), o entrave na utilização desses organismos como agentes de controle de insetos são os baixos níveis de mortalidade imediata atingidos e a necessidade de produção in vivo.

\subsubsection{Bactérias}

De forma semelhante ao que ocorre com vírus e protozoários, pouco se conhece sobre a patogenicidade de bactérias para baratas. Apesar disso, algumas bactérias provocam infecções em diferentes espécies. Bacillus thuringiensis, um dos microrganismos de amplo uso no controle de insetos pragas, é patogênico a um grande número de invertebrados, incluindo dictiópteros. Na lista de invertebrados suscetíveis ao $B t$, publicada por Glare \& O'Callaghan (2000), são citadas referências do efeito em laboratório de algumas subespécies da bactéria ou toxinas produzidas por estas para $B$. germanica e P. americana.

Segundo WeonDong et al. (2000), exotoxinas de Bacillus sp. apresentaram alta atividade inseticida sobre $P$. americana. A toxina causou alterações significativas em todo o corpo e na hemolinfa do inseto, induzindo uma desintegração citoplasmática das células epiteliais do mesêntero e do proctodéu.

Bacillus cereus, uma bactéria também com ampla gama de insetos hospedeiros, quando aplicado via oral ou por injeção na hemocele foi patogênico à barata Leucophaea maderae. Esse efeito parece estar diretamente relacionado com a produção da enzima fosfolipase $\mathrm{C}$ pela bactéria, causando danos nas células secretoras do intestino médio dos insetos que ingeriram o patógeno (Rahmet-Alla \& Rowley, 
1989). Adultos de B. orientalis criados em laboratório e infectados por Rickettsiella apresentaram inchaço do abdome e dificuldade de movimentação, levando a uma menor expectativa de vida e estagnação do crescimento da colônia (Radek, 2000).

\subsubsection{Nematóides}

A ocorrência e a capacidade infectiva de nematóides entomopatogênicos em baratas é um pouco mais conhecida e descrita na literatura. Assim como os protozoários, os nematóides parasitas intestinais, principalmente em Thelastomatoidea, são freqüentes em populações de baratas coletadas no campo (Tsai \& Cahill, 1970; Ebeling, 2002). A espécie de nematóide Blatticola blattae, que vive na porção posterior do aparelho digestivo de $B$. germanica e se alimenta possivelmente de bactérias, é uma das mais estudadas e pode ocasionar efeitos danosos ao desenvolvimento dos insetos. Segundo Müller-Graf et al. (2001), grupos de ninfas infectadas por esse parasita tem o desenvolvimento significativamente mais lento que grupos não infectados. O nematóide também causa um impacto negativo na sobrevivência dos insetos até a emergência dos adultos e na produção de ootecas pelas fêmeas. Estudos mais detalhados sobre a identificação e caracterização do parasitismo de nematóides telastomatídeos em baratas são encontrados nos trabalhos de Adamson \& VanWaerebeke (1992) e Adamson \& Noble (1992).

Outros grupos de nematóides merecem maior destaque, em especial os gêneros Steinernema e Heterorhabditis, que são encontrados em formulações comerciais para o controle de outras pragas. Koehler et al. (1992) demonstraram a suscetibilidade de P. americana, Periplaneta fuliginosa, B. orientalis, B. germanica e Supella longipalpa ao nematóide Steinernema carpocapse em condições de laboratório. Condições de alta umidade são de grande importância no sucesso do parasitismo e está relacionada com o ambiente que cada espécie de barata vive. Com esse mesmo nematóide foram observados índices de mortalidade de até $70 \%$ para $P$. americana em doses de 5.000 juvenis infectivos por inseto (Mathur et al., 1997). Além das espécies já citadas, outros

grupos infectam baratas, como por exemplo o nematóide ectoparasito Acugutturus 
parasiticus, da família Acugutturidae, que ocorre em P. americana (Hunt, 1980; Marti Jr. et al., 2000).

A atração de insetos para iscas armadilhas contendo nematóides vem recebendo considerável atenção em estudos de formulação e tecnologia de aplicação desse organismo (Georgis \& Kaya, 1998). Segundo Appel et al. (1993), armadilhas com o nematóide $S$. carpocapse são efetivas no controle de ninfas e adultos de $B$. germanica em residências, reduzindo significativamente a população da praga. Contudo, a baixa eficiência do nematóide em infectar ootecas, o que levaria à transmissão vertical do patógeno, pode ser um fator que limite a ocorrência de epizootias em populações de campo (Appel \& Benson, 1994).

Algumas empresas já se interessaram pela comercialização desse parasito em iscas atrativas. É o caso da norte-americana BioLogic Company, fundada na década de 1980 e que comercializa a isca BioRoach, uma câmara de infecção que contém o nematóide $S$. carpocapse em um gel atrativo para o controle de baratas.

\subsubsection{Fungos}

Dentre os microrganismos causadores de doenças em baratas, os fungos são certamente os mais importantes e estudados atualmente. Aproximadamente $80 \%$ das doenças em insetos têm como agentes etiológicos os fungos, pertencentes a cerca de 90 gêneros e mais de 700 espécies, sendo que a maioria dos gêneros já foi relatada no Brasil (Alves, 1998). Os fungos imperfeitos (Deuteromycotina: Hyphomycetes), patógenos com o ciclo de vida simples e de reprodução basicamente assexuada, possuem atividade sobre um grande número de insetos e ácaros praga e tornam-se os principais candidatos para o desenvolvimento de formulações comerciais (Lacey et al., 2001).

Estudos sobre a determinação da patogenicidade e do potencial de alguns fungos para o controle de baratas intensificaram-se nas últimas décadas. Infecções por leveduras, por exemplo, foram descritas em colônias de laboratório de B. germanica (Archbold et al., 1986) e P. americana (Verrett et al., 1987), causando mortalidade e redução da população. São freqüentes relatos das espécies Beauveria bassiana, 
Beauveria brongniartii, Metarhizium anisopliae, Verticillium lecanii, Paecilomyces fumosoroseus e Paecilomyces farinosus infectando e causando doença em baratas (Zukowski \& Bajan, 1996; Steenberg et al., 1997; Zukowski \& Bajan, 1997; Mohan et al., 1999). A espécie Aspergillus flavus, uma das mais frequentemente relacionada à aspergilose em humanos, é também reportada infectando $B$. germanica e levando à alterações fisiológicas e morte dos insetos. Possivelmente, esse fungo penetra o corpo do inseto por injúrias no tegumento (Kulshrestha \& Pathak, 1997; Pathak \& Kulshrestha, 1998).

Alguns esforços foram também dirigidos para a avaliação do efeito de micotoxinas no comportamento e sobrevivência de baratas. A toxina citrinina produzida pelo fungo Penicillium citrinum, quando injetada na hemocele, causa distúrbios nervosos que afetam a postura, locomoção e agilidade de $P$. americana e leva a morte dos insetos (Chandrashekhar et al., 1990). As destruxinas produzidas por M. anisopliae inibem ou reduzem a atividade dos hemócitos e o processo de melanização em baratas (Huxham et al., 1989a).

O fungo $M$. anisopliae é a espécie que vem recebendo maior atenção no desenvolvimento de programas e produtos para o controle de baratas, principalmente no que diz respeito a seu efeito sobre B. germanica e P. americana (Huxham et al., 1989b; Zimmermann, 1993). O comportamento de agregação da barata alemã, condicionado principalmente pela liberação de um feromônio nas fezes do inseto (Ishii \& Kuwahara, 1967; Sakuma \& Fukami, 1990; Matzger, 1995), juntamente com condições de alta umidade e temperatura dos esconderijos, pode favorecer a ocorrência de epizootias por esse fungo.

Seu uso em armadilhas atrativas (Gold, 1995) e aplicações de suspensões de conídios ou formulações em pó é comercialmente explorado em alguns países. $M$. anisopliae foi produzido comercialmente com o nome de Bio-Path ${ }^{\mathrm{TM}}$ pela empresa norte-americana Ecoscience. $\mathrm{O}$ produto consiste em uma câmara de infecção associada à uma isca atrativa para o controle de B. germanica. Na Guatemala, essa espécie de fungo é comercializada em formulação pó seco (Zero-QK) pela empresa Agricola El Sol, 
aplicado na forma de uma camada bem fina em residências e outros ambientes domésticos.

As maiores limitações do uso de M. anisopliae para o controle de baratas são o longo tempo necessário para se observar índices de mortalidade satisfatórios e a performance inconsistente dos produtos em condições de campo. Tais razões levaram, por exemplo, a retirada da isca Bio-Path ${ }^{\mathrm{TM}}$ do mercado norte-americano. Uma das opções que vem sendo muito estudada nos últimos anos é a incorporação ou associação desse patógeno com inseticidas químicos, visando eliminar justamente os problemas relacionados à variação da eficiência do fungo em aplicações em campo (Kaakeh et al., 1997a; Pachamuthu et al., 1999; Pachamuthu \& Kamble, 2000; Zurek et al., 2002). Nesses casos, são preferidos inseticidas de baixa toxicidade ao homem e animais domésticos e compatíveis com o fungo. Procura-se assim desenvolver um produto com as vantagens de um bioinseticida, como a segurança para aplicações em ambientes domésticos, a possibilidade de manejar a resistência de populações a outros inseticidas e o efeito em cadeia do patógeno, mas com eficiência satisfatória e semelhante a dos produtos convencionais. 


\title{
3 CONTROLE DE Blattella germanica (DICTYOPTERA: BLATTELLIDAE) COM Metarhizium anisopliae EM LABORATÓRIO
}

\author{
Autor: ROGÉRIO BIAGGIONI LOPES \\ Orientador: Prof Dr. SÉRGIO BATISTA ALVES
}

\section{Resumo}

Determinou-se em condições de laboratório a estimativa da dose-resposta de M. anisopliae para ninfas e adultos de Blattella germanica e sua infectividade via oral e por meio do caminhamento dos insetos em uma superfície contaminada. As mortalidades médias corrigidas de adultos e ninfas para as concentrações testadas variaram de $28,2 \%$ a $79,5 \%$ e de $16,1 \%$ a $44,1 \%$, respectivamente. A estimativa da DL50 obtida para adultos foi de $2,7 \times 10^{5}$ conídios $\left(5,4 \times 10^{4}-8,1 \times 10^{5}\right.$ conídios $), 15$ dias após a inoculação, havendo uma relação linear entre a dose utilizada e a mortalidade do inseto. A presença do fungo não afetou a quantidade de isca consumida pelos insetos nas concentrações testadas. Não foi observado mortalidade de ninfas de B. germanica expostas durante 72 horas ao alimento contaminado com $M$. anisopliae nas concentrações de $1 \%$, 5\% e $10 \%$. A mortalidade dos adultos variou entre $12 \%$ e $22 \%$ após 15 dias da aplicação. Após 48 horas do início da alimentação de adultos na isca contaminada, conídios de $M$. anisopliae foram encontrados inviáveis nas três porções do trato digestivo. Quando os insetos foram expostos à superfície contaminada com a formulação em pó nas concentrações de $1 \%, 5 \%$ e 10\%, a mortalidade variou entre 59,3 e 82,3\% para ninfas e entre 55,2 e 96,9\% para adultos, apenas 9 dias após a aplicação. No caso de adultos, observou-se na menor concentração mortalidade acima de $85 \%$ após 
15 dias, e na maior concentração esse índice atingiu 100\%. A aplicação de M. anisopliae em formulações em pó causou altos índices de mortalidade de B. germanica, entretanto, o longo período necessário para se obter tais índices sugere a busca de agentes que potencializem a ação do patógeno. 


\title{
3 CONTROL OF Blattella germanica (DICTYOPTERA: BLATTELLIDAE) WITH Metarhizium anisopliae IN LABORATORY CONDITIONS
}

\author{
Author: ROGÉRIO BIAGGIONI LOPES \\ Adviser: Prof Dr. SÉRGIO BATISTA ALVES
}

\section{Summary}

The studies conducted with the fungus Metarhizium anisopliae aiming at controlling urban pests are still inceptive, although this entomopathogen have been largely applied in the agriculture. It was determined in laboratory conditions the estimate lethal dose of $M$. anisopliae for Blattella germanica nymphs and adults, its oral infectivity and the infectivity through insects moving on a contaminated surface. The mortality rates of adults and nymphs for the tested concentrations ranged from $28.21 \%$ to $79.48 \%$, and from $16.13 \%$ to $44.05 \%$, respectively. The estimative of the $\mathrm{LD}_{50}$ obtained for adults was $2.69 \times 10^{5}$ conidia $\left(5.43 \times 10^{4}-8.06 \times 10^{5}\right.$ conidia), 15 days after the inoculation, and a liner relation was observed between the dose that was used and the mortality rate. It was not possible to determine the $\mathrm{DL}_{50}$ for nymphs, since the mortality rate with the greatest dose was low. The presence of fungus did not affect the bait quantity ingested by the insects in the concentrations that were tested. There was no mortality of B. germanica nymphs exposed for 72 hours to the food contaminated with M. anisopliae in the concentrations of $1 \%, 5 \%$ and $10 \%$. The mortality rate of adults ranged from $12 \%$ to $22 \%, 15$ days after the application. Forty-eight hours after the adults started feeding at the contaminated bait, M. anisopliae conidia were present in three portions of the digestive tract, however, they were no viable. When the insects were exposed to the surface that had been contaminated with the fungus formulation in the concentrations of $1 \%, 5 \%$ and $10 \%$, the mortality rate ranged from 59.27 to $82.29 \%$ for the nymphs, and from 55.21 to $96.87 \%$ for the adults, only 9 days after the application. In the case of the adults, it was noted in the lowest concentration a mortality rate over $85 \%, 15$ days after the application, and in the greatest concentration, this rate reached 
$100 \%$. The application of M. anisopliae in powder formulation is effective to obtain high mortality rates of B. germanica. However, the long period necessary to obtain such rates proposes the search of agents that enhance the pathogen action. 


\subsection{Introdução}

O fungo Metarhizium anisopliae ocorre infectando naturalmente mais de 200 espécies de insetos em diferentes ordens e pode ser considerado um importante agente de controle biológico de pragas. Esse patógeno tem ampla distribuição geográfica podendo ser facilmente isolado de amostras de solo e de diversos artrópodes (Zimmermann, 1993). Seu emprego na agricultura vem sendo difundido e, em alguns casos, já é considerado um importante agente de controle de pragas em diversos países da América Latina, sendo muito utilizado para o controle de cigarrinhas em pastagens e na cana-de-açúcar (Alves et al., 2002b).

Apesar da considerável evolução das pesquisas com $M$. anisopliae e de seu uso no setor agrícola, são poucas as referências sobre a aplicação desse fungo para o controle de pragas em ambientes urbanos. Em relação às baratas, especialmente Blattella germanica, algumas pesquisas já avaliaram o potencial de linhagens do patógeno no que diz respeito à sua virulência (Steenberg et al., 1997; Pachamuthu et al., 1999), capacidade de transmissão horizontal (Kaakeh et al., 1996) e sua associação com inseticidas químicos (Kaakeh et al., 1997a; Pachamuthu \& Kamble, 2000; Zurek et al., 2002). Algumas características comportamentais das baratas, como o hábito de viverem agregadas, e as condições de alta umidade e temperatura dos esconderijos, podem favorecer a ação desse patógeno sobre a população, levando à infecções secundárias ou favorecendo a ocorrência de epizootias.

O uso de inseticidas químicos em ambientes domiciliares e em locais de armazenamento e manipulação de alimentos pode provocar a contaminação do homem e animais domésticos. Estratégias biológicas de controle das baratas, que incluem o emprego de $M$. anisopliae, podem reduzir esses riscos e proporcionar um efeito mais duradouro.

Embora o fungo $M$. anisopliae seja considerado um eficiente agente de controle de $B$. germanica, o período de tempo necessário para obtenção de altos níveis de mortalidade deixa dúvidas quanto seu uso prático no mercado domissanitário. Diferentes estratégias de aplicação desse patógeno podem influenciar diretamente na sua 
eficiência de controle, favorecendo a maior infecção e reduzindo seu tempo de ação sobre os insetos. O presente estudo teve como objetivo avaliar a eficiência do fungo $M$. anisopliae para ninfas e adultos de B. germanica e a infectividade desse patógeno em aplicações por meio de isca atrativa e de superfície contaminada em condições de laboratório.

\subsection{Material e Métodos}

\subsubsection{Criação de Blattella germanica em laboratório}

A população mantida no Laboratório de Patologia e Controle Microbiano de Insetos do Departamento de Entomologia, Fitopatologia e Zoologia Agrícola da ESALQ-USP desde 1998 foi coletada em estabelecimentos comerciais em Piracicaba (SP). Os insetos foram criados em recipientes de vidro $(55 \times 25 \times 30 \mathrm{~cm})$, cobertos com um tecido de malha fina e uma camada de vaselina líquida na borda superior interna para evitar a fuga dos insetos e permitir a ventilação (metodologia adaptada de Singh \& Moore, 1985). Como abrigo foram utilizados cartuchos de papelão corrugado sobrepostos e dispostos horizontalmente ao fundo do recipiente. Semanalmente foi feito o fornecimento de água em bebedouros plásticos e alimento (ração de cachorro) suficientes para o bom desenvolvimento da população. Os recipientes foram mantidos em sala escura (24 horas de escotofase) e temperatura em torno de $27 \pm 2^{\circ} \mathrm{C}$. Quando necessário, a população foi removida para a limpeza dos recipientes, retirando-se as fezes e insetos mortos.

\subsubsection{Produção do inóculo do fungo Metarhizium anisopliae (ESALQ-1037)}

O fungo M. anisopliae (linhagem ESALQ1037), isolado de Solenopsis sp. procedente de Porto Alegre-RS, encontra-se armazenado no banco de entomopatógenos do laboratório, na forma de conídios puros em freezer $\left(-4^{\circ} \mathrm{C}\right)$ e em meio de cultura sob óleo mineral. 
Pequenas quantidades de conídios foram transferidas para placas de Petri contendo meio de cultura sólido completo $\left(0,36 \mathrm{~g} \quad \mathrm{KH}_{2} \mathrm{PO}_{4} ; 1,05 \mathrm{~g} \quad \mathrm{Na}_{2} \mathrm{HPO}_{4} ; 0,6 \mathrm{~g}\right.$ $\mathrm{MgSO}_{4} ; 1,0 \mathrm{~g} \mathrm{KCl} ; 1,58 \mathrm{~g} \mathrm{NaNO}_{3} ; 10 \mathrm{~g}$ glicose anidra; $5 \mathrm{~g}$ extrato de levedura; $20 \mathrm{~g}$ ágar; 1000ml água destilada) e espalhadas com o auxílio de uma alça de Drigalsky. As placas foram incubadas em câmara climatizada sob temperatura de $26 \pm 0,5^{\circ} \mathrm{C}$ e fotofase de 12 horas, durante um período de sete dias para produção de conídios. Após este período, os conídios foram raspados com uma espátula de metal estéril e armazenados em ependorff à temperatura de $-40^{\circ} \mathrm{C}$, constituindo o inóculo utilizado em todos os testes. Os conídios utilizados nos testes apresentavam viabilidade acima de $95 \%$.

\subsubsection{Estimativa da dose-resposta de Metarhizium anisopliae (ESALQ-1037) para Blattella germanica}

Nesta etapa, foi avaliada a atividade do fungo $M$. anisopliae sobre adultos e ninfas de B. germanica por meio de aplicação tópica. Para os insetos adultos, cada tratamento consistiu de 96 insetos, divididos em seis repetições com oito machos e oito fêmeas cada, coletados diretamente dos recipientes de criação. Foram separados adultos com maior atividade e mobilidade, evitando-se insetos lentos e moribundos. No caso da fase imatura, foram utilizadas ninfas de 20 a 22 dias de idade, com seis repetições de 16 ninfas para cada tratamento, totalizando também 96 insetos. Para a obtenção das ninfas de idade conhecida, fêmeas com ootecas escurecidas e bem desenvolvidas foram anestesiadas com gás $\mathrm{CO}_{2}$ e separadas das ootecas pressionando-se cuidadosamente com uma pinça a porção final do abdome do inseto. As ootecas foram mantidas em copos plásticos com tampa e um algodão umedecido em câmara climatizada $\left(27 \pm 1^{\circ} \mathrm{C}\right.$ e escotofase de 24 horas) até a eclosão das ninfas. Água e alimento foram fornecidos até as ninfas atingirem a idade desejada para o teste.

As suspensões do patógeno foram preparadas misturando-se conídios retirados de culturas puras em água estéril mais espalhante adesivo $\left(0,1 \mathrm{~mL} / \mathrm{L}\right.$ de Tween $\left.20^{\circledR}\right)$ e padronizadas nas concentrações pré-determinadas com auxílio da câmara de Neubauer. As concentrações foram determinadas em experimentos prévios com adultos. Foram 
avaliadas para adultos e ninfas as concentrações de $2 \times 10^{7}, 6,3 \times 10^{7}, 2 \times 10^{8}, 6,3 \times 10^{8}$ e $2 \times 10^{9}$ conídios do fungo por mililitro de suspensão, além da testemunha que recebeu apenas água estéril com espalhante adesivo.

As baratas (ninfas e adultos) foram anestesiadas com gás $\mathrm{CO}_{2}$ por 20 segundos e cada inseto foi inoculado com $1 \mu \mathrm{L}$ da suspensão de conídios na região esternal, entre as coxas do terceiro par de pernas, por meio de uma microseringa de vidro acoplada a um microaplicador automático (Microaplicador Burkard Manufacturing Co. Ltd.). Após a inoculação, os insetos foram transferidos para copos plásticos transparentes $(6 \mathrm{~cm}$ de altura e $10 \mathrm{~cm}$ de diâmetro) com tampa com pequenos orifícios circulares, contendo água e alimento, e mantidos em câmara climatizada $\left(27 \pm 1^{\circ} \mathrm{C}\right.$ e escotofase de 24 horas).

As avaliações foram realizadas a cada três dias, durante um período de 15 dias, anotando-se o número de insetos mortos em cada repetição. Os cadáveres foram, posteriormente, transferidos para placas com algodão umedecido para confirmação da

mortalidade pelo fungo. Os dados de mortalidade ao final do experimento foram submetidos à análise de Probit (POLO-PC) para determinação da curva dose-resposta e a estimativa da $\mathrm{DL}_{25}$ e $\mathrm{DL}_{50}$.

\subsubsection{Avaliação da infectividade de Metarhizium anisopliae (ESALQ-1037)}

Foi avaliada a infectividade do patógeno sobre adultos e ninfas por duas vias de inoculação, que simulam as duas formas de aplicação do fungo em campo: a) por meio do caminhamento dos insetos em uma superfície contaminada com o fungo; b) via oral, por ingestão do fungo associado a uma isca atrativa. Os copos plásticos e os insetos utilizados nos testes, tanto adultos quanto ninfas de 20 a 22 dias de idade, foram separados da mesma maneira descrita no ítem anterior.

No teste de contato direto ou caminhamento, conídios de M. anisopliae foram misturados em talco mineral nas concentrações de 1\%,5\% e 10\%, que corresponderam aos diferentes tratamentos, além da testemunha cujos insetos foram inoculados apenas com talco. Em cada tratamento foram preparados seis azulejos de 15 x $15 \mathrm{~cm}$ com 
0,0013 gramas da formulação por $\mathrm{cm}^{2}$, espalhadas de maneira uniforme com o auxílio de um pincel. Os insetos foram anestesiados com $\mathrm{CO}_{2}$ e transferidos em grupos de 16 indivíduos para cada azulejo, onde foi colocado o copo plástico com a boca voltada para baixo, confinando os insetos na superfície tratada com o patógeno. A borda interna dos copos recebeu uma fina camada de vaselina obrigando as baratas a caminharem na superfície contaminada. Após o efeito da anestesia os insetos permaneceram confinados nessa condição durante 10 minutos e depois foram induzidos a caminhar, com o auxílio do próprio copo, para um outro azulejo não tratado disposto lateralmente ao azulejo tratado. O conjunto copo e azulejo foi posteriormente virado 180 graus para transferir os insetos para o interior do copo, evitando assim que resíduos da formulação que permaneceram no azulejo tratado contaminassem a porção interna do recipiente. Foi fornecido água e alimento e os tratamentos permaneceram em condições controladas $\left(27 \pm 1{ }^{\circ} \mathrm{C}\right.$ e escotofase de 24 horas) até o final da avaliação.

Nos testes de infecção via oral, as iscas atrativas foram preparadas com leite em pó e extrato de levedura também em pó, na proporção de 5:1, e os conídios de $M$. anisopliae misturados nas proporções de 1\%, 5\% e 10\% do peso. A isca foi colocada em comedouros plásticos em forma de tubo $(3 \mathrm{~cm}$ de comprimento e $0,5 \mathrm{~cm}$ de diâmetro) com apenas uma das extremidades aberta. Foram preparados seis comedouros para cada tratamento. Cada repetição, que consistiu de um copo plástico com 16 insetos, recebeu um comedouro contendo $0,25 \mathrm{~g}$ da isca, que permaneceu como o único alimento dos insetos durante apenas as primeiras 72 horas. Após esse período, as iscas tratadas foram retiradas fornecendo-se alimento não contaminado. O tratamento testemunha consistiu das mesmas iscas, porém preparadas sem o fungo. Além do alimento, água foi fornecida durante todo o experimento. Os tratamentos permaneceram em condições controladas $\left(27 \pm 1{ }^{\circ} \mathrm{C}\right.$ e escotofase de 24 horas) até o final das avaliações.

Para os dois métodos de inoculação, as avaliações foram realizadas a cada três dias, durante um período total de 15 dias, anotando-se o número de insetos mortos em cada repetição. Os cadáveres foram, posteriormente, transferidos para placas com algodão umedecido para confirmação da mortalidade pelo fungo. No experimento com iscas contaminadas foi avaliado também o consumo médio das iscas pelos adultos no 
período de exposição (72 horas), determinando-se assim o possível efeito de repelência do patógeno. O delineamento foi inteiramente casualizado e os dados de mortalidade dos dois métodos de inoculação e de consumo de isca pelos adultos foram submetidos à análise de variância e as médias comparadas pelo teste de Tukey $(\mathrm{P}<0,05)$.

Foi também avaliada a viabilidade dos conídios de $M$. anisopliae na isca contaminada (1\%) e na formulação em talco (1\%) armazenados a $27 \pm 1{ }^{\circ} \mathrm{C}$, após 1,72 e 120 horas do preparo das mesmas. Para isso, 0,1 grama da isca ou da formulação em talco foi adicionado a $9,9 \mathrm{~mL}$ de água destilada e a suspensão agitada vigorosamente durante dois minutos. Após diluições sucessivas, $0,1 \mathrm{~mL}$ da suspensão foi plaqueado em meio BDA (200g batata; 15g dextrose; 0,5g streptomicina; 20g ágar; 1000ml água destilada) e as placas incubadas em câmara climatizada $\left(26 \pm 0,5^{\circ} \mathrm{C}\right.$ e 12 horas de fotofase). Decorrido um período de 120 horas foi avaliado o número de unidades formadoras de colônia (UFC) nas placas, determinando-se o número de conídios viáveis por grama da isca e da formulação em talco.

\subsubsection{Atividade de conídios de Metarhizium anisopliae (ESALQ-1037) nos sistemas respiratório e digestivo de Blattella germanica}

Dois grupos de 40 adultos de $B$. germanica, divididos em quatro repetições de 10 insetos cada, foram confinados em copos plásticos durante 48 horas. Nesse período, cada recipiente de um dos grupos recebeu 1 grama de alimento (leite em pó e extrato de levedura na proporção de 5:1) contaminado com conídios de $M$. anisopliae (1\%). No outro grupo, o fundo de cada recipiente foi tratado com 0,1 grama da formulação talco $1 \%$. Ao final de 48 horas, os insetos foram anestesiados com $\mathrm{CO}_{2}$ e dissecados em placa de Petri contendo água destilada, com auxílio de um esteroscópio (x 6,4).

Para os insetos inoculados com o alimento contaminado, todo o trato digestivo foi retirado por um corte transversal da porção ventral do abdome e transferido para uma lâmina de vidro. Vinte aparelhos digestivos, separados previamente em três partes (estomodéu, mesêntero e proctódeu), foram avaliados diretamente em microscópio óptico, observando-se a presença de estruturas do patógeno e sua fase de 
desenvolvimento. Os aparelhos digestivos restantes foram abertos e o conteúdo interno transferido para placas de Petri com meio BDA. As placas foram incubadas em câmara climatizada $\left(27^{\circ} \mathrm{C}\right.$ e 12 horas de fotofase) durante 48 horas. Com o auxílio de um microscópio óptico foi determinada a porcentagem de germinação dos conídios contidos no trato digestivo dos insetos.

No caso do insetos inoculados com a formulação talco, as traquéias abdominais mais grossas foram removidas cuidadosamente e transferidas para lâminas de vidro em uma gota de corante azul lático. As lâminas foram posteriormente observadas em microscópio óptico quanto a presença de conídios germinados e não germinados no sistema traqueal da barata.

\subsection{Resultados e Discussão}

\subsubsection{Estimativa da dose-resposta de Metarhizium anisopliae (ESALQ-1037) para Blattella germanica}

As mortalidades médias corrigidas (Schneider-Orrelli, 1947) de adultos e ninfas de $B$. germanica para as concentrações testadas variaram de $28,21 \%$ a $79,48 \%$ e de $16,13 \%$ a 44,05\%, respectivamente. Os insetos mortos pelo fungo, quando submetidos à condição de alta umidade, apresentaram nas regiões intersegmentares do corpo um crescimento micelial inicialmente branco e, posteriormente verde-oliva, característica do fungo e do processo de conidiogênese. Para os insetos que não receberam tratamento a mortalidade média foi inferior a $15 \%$.

O valor da $\mathrm{DL}_{50}$ obtido para adultos foi de $2,69 \times 10^{5}$ conídios $\left(=2,69 \times 10^{8}\right.$ conídios $/ \mathrm{mL}$ ), com limites entre $5,43 \times 10^{4}$ e $8,06 \times 10^{5}$ conídios (I.C. $90 \% ; t=5,23 ; \chi^{2}=$ 5,02). Não foi possível determinar a DL50 para ninfas, já que a mortalidade na maior dose foi inferior a $50 \%$. Nesse caso, a $\mathrm{DL}_{25}$ para ninfas foi de $1,25 \times 10^{5}$ conídios $\left(=1,25 \times 10^{8}\right.$ conídios/mL), com limites entre $4,78 \times 10^{4}$ e $2,45 \times 10^{5}$ conídios (I.C. $90 \% ; t=$ 5,$\left.08 ; \chi^{2}=0,63\right)$. De acordo com a análise, rejeitou-se a hipótese das retas de mortalidade serem as mesmas e existe paralelismo entre elas, indicando que a resposta ao mecanismo 
de infecção do patógeno e ao processo-doença seguem um mesmo padrão para as duas fases de desenvolvimento do inseto (Figura 3).

$\mathrm{O}$ valor da $\mathrm{DL}_{25}$ observada para ninfas foi quase cinco vezes maior que a estimativa da $\mathrm{DL}_{25}$ para adultos $\left(2,67 \times 10^{4}\right.$ conídios $)$, indicando uma menor sensibilidade da fase imatura à infecção por M. anisopliae. Contudo, não foi possível a obtenção do valor da $\mathrm{DL}_{25}$ para adultos e a comparação direta com o valor obtido para as ninfas, já que a mortalidade de adultos na menor dose do patógeno foi elevada. A perda de parte do inóculo aplicado, que fica aderido ao tegumento antigo após o processo da ecdise e mudança de ínstar da ninfa, poderia explicar tal efeito.

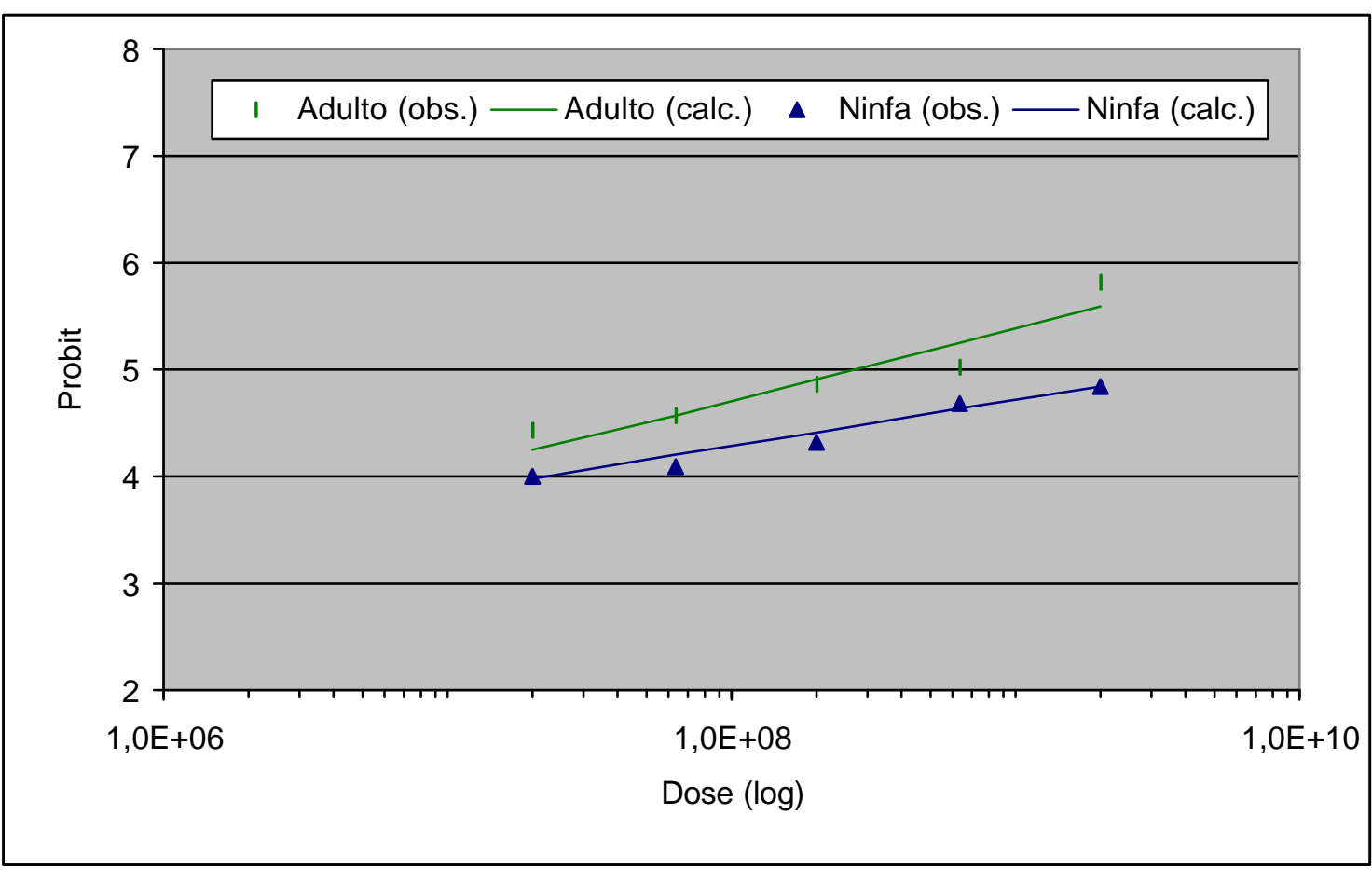

Figura 3 - Curva dose-resposta expressa pela mortalidade de ninfas e adultos de Blattella germanica 15 dias após a aplicação de Metarhizium anisopliae em laboratório. Reta $=$ valores de probit calculado; pontos $=$ valores de probit observados

Apesar da baixa mortalidade nas doses inferiores a $2 \times 10^{5}$ conídios por inseto, especialmente para ninfas, existe uma relação linear entre a dose utilizada e a 
mortalidade observada. Altas doses do patógeno são necessárias para obtenção de elevados índices de mortalidade de $B$. germanica. Estudos anteriores também comprovam a eficiência de diferentes linhagens de $M$. anisopliae no controle dessa espécie de barata (Kaakeh et al., 1996; Kaakeh et al., 1997a; Pachamuthu \& Kamble, 2000). As faixas de mortalidade e o valor da $\mathrm{DL}_{50}$ para adultos de $B$. germanica são semelhantes às obtidas por Pachamuthu et al. (1999) para a mesma espécie de fungo (linhagem ESC-1). Esses autores observaram, depois de 21 dias da inoculação, mortalidade total entre $31 \%$ e $86 \%$ para doses entre $8 \times 10^{4}$ e $2 \times 10^{6}$ conídios e $\mathrm{DL}_{50}$ de $4,18 \times 10^{5}$ conídios, em condições experimentais semelhantes. A pequena diferença entre os valores de mortalidade observada pelos autores em comparação ao presente estudo deve-se, principalmente, à variações da atividade dos isolados e ao tempo de avaliação.

Apesar da eficiência do patógeno em altas doses, são necessários períodos de tempo superiores a 15 dias para obtenção de índices satisfatórios de mortalidade. Uma das maiores limitações da câmara de infecção Bio-Path ${ }^{\mathrm{TM}}$, já comercializada nos Estados Unidos pela EcoScience Corp. e que teve sua produção interrompida, foi justamente o longo período requerido para ação do fungo. Esse tempo depende da linhagem do patógeno, das condições de temperatura e umidade em que ocorre a infecção e dos mecanismos de defesa do inseto, incluindo os mecânicos, celulares e comportamentais.

A espessura do tegumento das baratas consiste em uma barreira física importante, que dificulta a penetração pelo fungo. Na resposta celular destacam-se os processos de fagocitose, encapsulação e nodulação das estruturas infectivas do patógeno. Gunnarsson \& Lackie (1985) detectaram a formação de nódulos quando conídios de $M$. anisopliae foram injetados no hemocele de Periplaneta americana. A resposta imunológica do inseto pode também variar em função da linhagem do patógeno, como demonstrado por Huxham et al. (1989b) em estudos da atividade de hemócitos de $P$. americana em infecções causadas por M. anisopliae.

Aspectos comportamentais, também podem atuar de modo negativo ou positivo na velocidade de morte dos insetos. A agregação de indivíduos, um comportamento típico das baratas, pode favorecer o desenvolvimento de doença em populações de insetos, especialmente as causadas por fungos entomopatogênicos. Tal 
efeito ocorre, por exemplo, com a praga do coqueiro Brassolis sp., em que a agregação das lagartas durante o dia em invólucros de seda nas folhas favorece a disseminação de Paecilomyces sp. e B. bassiana de indivíduos infectados para outros sadios, em virtude das condições favoráveis de umidade e temperatura e do constante contato entre insetos (Alves \& Lecuona, 1998). No ambiente em que se desenvolvem altas populações de baratas, caracterizado por umidade e temperatura elevadas, o fungo encontra condições muito favoráveis para se reproduzir sobre o cadáver de indivíduos infectados, permitindo a contaminação de outros insetos da colônia.

No que diz respeito aos insetos sociais, a agregação pode trazer vantagens à colônia para evitar a ocorrência de determinadas doenças. Formigas produzem substâncias fungistáticas que afetam o desenvolvimento de alguns fungos. Os cupins e as abelhas possuem hábitos de limpeza que eliminam focos primários de doenças (Alves \& Lecuona, 1998). Boucias et al. (1996) observaram que o mecanismo de limpeza entre indivíduos de Reticulitermes flavipes tem um efeito de proteção contra infecções causadas por B. bassiana, e que agentes estressores, no caso o inseticida imidacloprid, provocam alterações nesse comportamento. Contudo, insetos de hábito gregário e não sociais como as baratas, geralmente, não possuem tais mecanismos de defesa, tornandoos mais suscetíveis a ação de fungos entomopatogênicos.

Outras espécies de insetos reagem ao processo infectivo por M. anisopliae de modo diferente. No caso de tripes, por exemplo, de tamanho bem menor e com o tegumento menos esclerotizado, a ação do fungo é mais rápida, ocorrendo a morte do inseto mesmo antes da completa colonização, provavelmente, pela ação de destruxinas e/ou outras substâncias químicas produzidas no processo de infecção (Vestergaard et al., 1995; Lopes, 1999). A rápida mortalidade também ocorre para o ácaro Tetranychus urticae infectado por M. anisopliae (Tamai et al., 2002a). Nesse caso, a morte ocorreu a partir do terceiro dia da contaminação, no início do processo de colonização, fase em que também foi observada a formação de cristais de oxalato de cálcio dentro do corpo do ácaro. Segundo os autores, a formação dos cristais pode ser o resultado do metabolismo do patógeno na colonização e deve interferir nas atividades normais de funcionamento do órgãos dos ácaros. 


\subsubsection{Avaliação da infectividade de Metarhizium anisopliae (ESALQ-1037)}

Não se observou a mortalidade de ninfas de $B$. germanica que receberam alimento contaminado com $M$. anisopliae, nas três concentrações avaliadas. Para adultos, ocorreu mortalidade entre $12 \%$ e $22 \%$ após 15 dias da aplicação. A maior concentração (10\%) provocou mortalidade apenas de $21,12 \%$ e diferiu estatisticamente da testemunha $(8,21 \%)$ (Tabela 2 e Figura 4$)$.

Tabela 2. Mortalidade média de ninfas e adultos de Blattella germanica expostos à isca contaminada com Metarhizium anisopliae (ESALQ1037) em diferentes concentrações

$\%$ DE MORTALIDADE

NINFAS (20-22 dias de idade)

ADULTOS

\begin{tabular}{lccccc} 
TRATAMENTOS & 9 dias & 15 dias $^{1}$ & 9 dias $^{\text {n.s. }}$ & \multicolumn{2}{c}{15 dias $^{1}$} \\
\hline Testemunha & 1,04 & 1,04 & 3,12 & 8,21 & a \\
Formulação 1\% & 1,04 & 1,04 & 10,42 & 19,79 & ab \\
Formulação 5\% & 0,00 & 0,00 & 8,33 & 12,50 & ab \\
Formulação 10\% & 0,00 & 1,04 & 9,21 & 21,12 & b
\end{tabular}

Médias seguidas de mesma letra não diferem entre si pelo teste de Tukey $(\mathrm{P}<0.05)$

n.s. não significativo a $5 \%$ de probabilidade

${ }^{1}$ dias após a aplicação dos tratamentos

O fungo não afetou o consumo das iscas contaminadas pelos insetos em nenhuma das concentrações testadas. A média de consumo por adultos das iscas tratadas $(0,12 \mathrm{~g})$ foi a mesma que a isca sem o patógeno $(0,12 \mathrm{~g})$ durante o período de alimentação de 72 horas.

Diferentemente do que foi observado para a inoculação via oral, usando-se a isca contaminada, a mortalidade de ninfas e adultos de B. germanica foi elevada quando os insetos foram submetidos à superfície contaminada pelo patógeno. Para ninfas, observou-se mortalidade entre 59 e $83 \%$ decorridos apenas 9 dias da aplicação, sendo que todas as concentrações diferiram da testemunha. Para os adultos, após 9 dias nas 
concentrações de $5 \%$ e $10 \%$ as mortalidades foram de 93,75\% e 96,87\%, respectivamente. Após 15 dias, na concentração mais baixa, observou-se mortalidade acima de $85 \%$ e na maior concentração esse índice atingiu $100 \%$ (Tabela 3). O tempo necessário para causar altos índices de mortalidade com esse método de inoculação, tanto para adultos quanto para ninfas, foi menor quando comparado com a aplicação tópica. No caso de adultos, a mortalidade na maior dose não atingiu $60 \%$ ao nono dia na aplicação tópica, contudo, para as concentrações de 5\% e $10 \%$ em superfície contaminada os índices de mortalidade foram superiores à $90 \%$ no mesmo período (Figura 5). Para ninfas, essa diferença foi ainda muito mais evidente, quando a mortalidade na aplicação em superfície contaminada atingiu entre $60 \%$ e $70 \%$ com apenas 3 dias (Figura 6).

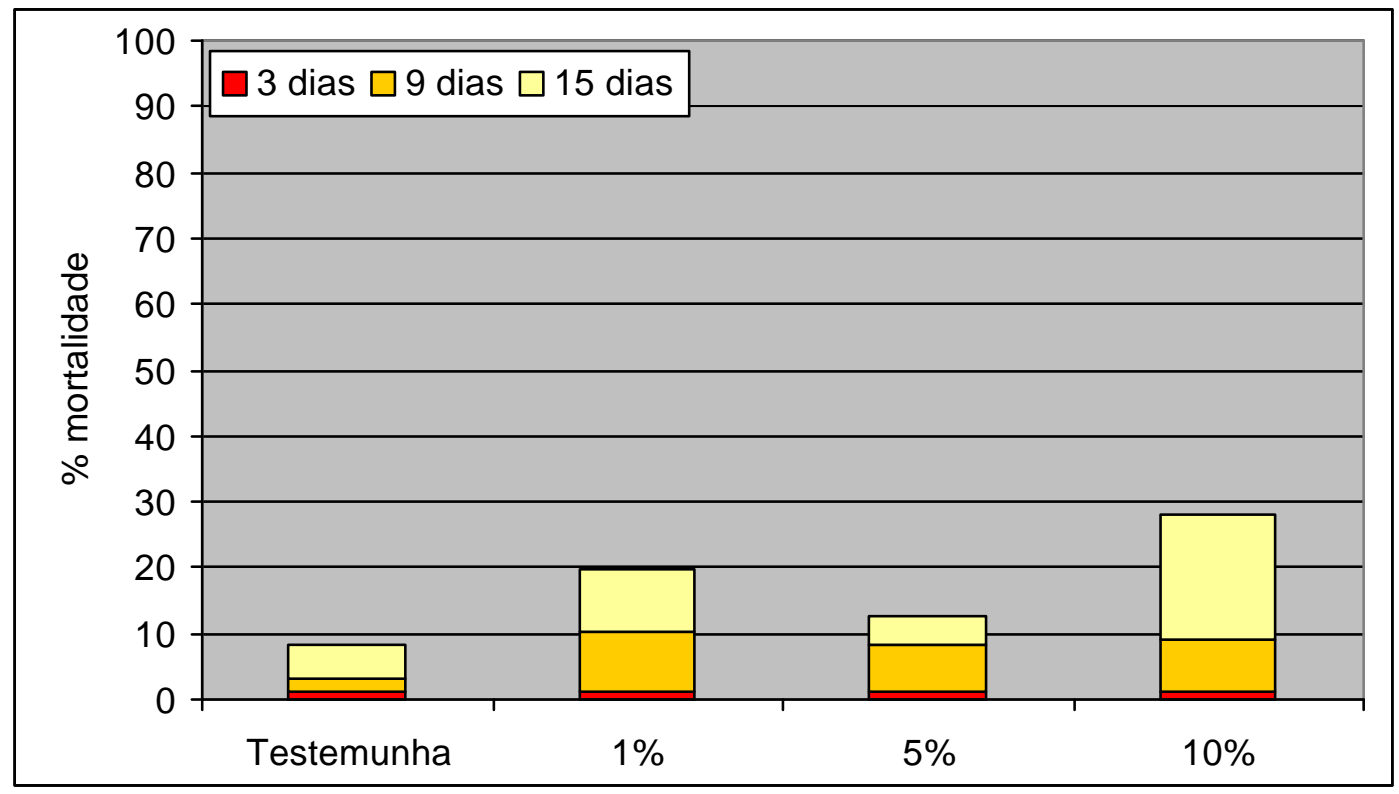

Figura 4 - Mortalidade de adultos de Blattella germanica expostos à isca contaminada com Metarhizium anisopliae (ESALQ1037) em diferentes concentrações

Tanto na isca contaminada quanto na formulação em talco, não foi observado redução na viabilidade do patógeno com 72 horas de armazenamento em temperatura ambiente. No caso da formulação em talco, a manutenção da alta viabilidade (100\%) 
estendeu-se até 120 horas de armazenamento. Porém, na isca contaminada, o número de unidades formadoras de colônia (UFC) após 120 horas $\left(1,67 \times 10^{6}\right.$ UFC/grama) foi cerca de 100 vezes menor quando comparado com o valor observado com 1 hora de armazenamento $\left(1,57 \times 10^{8} \mathrm{UFC} /\right.$ grama $)$, logo após o preparo da isca. A estabilidade dos conídios de $M$. anisopliae na formulação é importante para se determinar o período de atividade do fungo em aplicações no campo. No entanto, esse é um dos grandes problemas a serem resolvidos para otimização do uso desses produtos.

Tabela 3. Mortalidade média de ninfas e adultos de Blattella germanica expostos à superfície contaminada com Metarhizium anisopliae (ESALQ1037)

$\%$ DE MORTALIDADE

NINFAS (20-22 dias de idade) ${ }^{1}$

ADULTOS

\begin{tabular}{lcccccccc} 
TRATAMENTOS & 9 dias & & & 15 dias $^{2}$ & & 9 dias & & \multicolumn{2}{c}{15 dias $^{2}$} \\
\hline Testemunha & 1,04 & a & 1,04 & a & 7,29 & a & 16,67 & a \\
Formulação $1 \%$ & 59,37 & b & 60,42 & b & 55,21 & b & 86,46 & b \\
Formulação $5 \%$ & 82,29 & b & 83,33 & b & 93,75 & c & 98,96 & c \\
Formulação 10\% & 73,96 & b & 76,04 & b & 96,87 & c & 100,00 & c
\end{tabular}

Médias seguidas de mesma letra não diferem entre si pelo teste de Tukey $(\mathrm{P}<0.05)$

1 dados transformados $(\sqrt{ } \mathrm{x}+1)$

2 dias após a aplicação dos tratamentos

A quantidade de estruturas infectivas do fungo adquirida pelo indivíduo e a via de infecção são fatores que estão diretamente relacionados com a velocidade do processo de doença nos insetos. Os fungos são organismos que atuam, principalmente, por contato, penetrando o exoesqueleto por ação mecânica e enzimática e colonizando o inseto a partir desse mecanismo de invasão (Gupta et al., 1991; St. Leger et al., 1991; Alves, 1998). Pode também ocorrer a infecção via aberturas naturais, como os espiráculos, boca e ânus, porém em menor intensidade, variável ainda com a espécie da praga envolvida. 


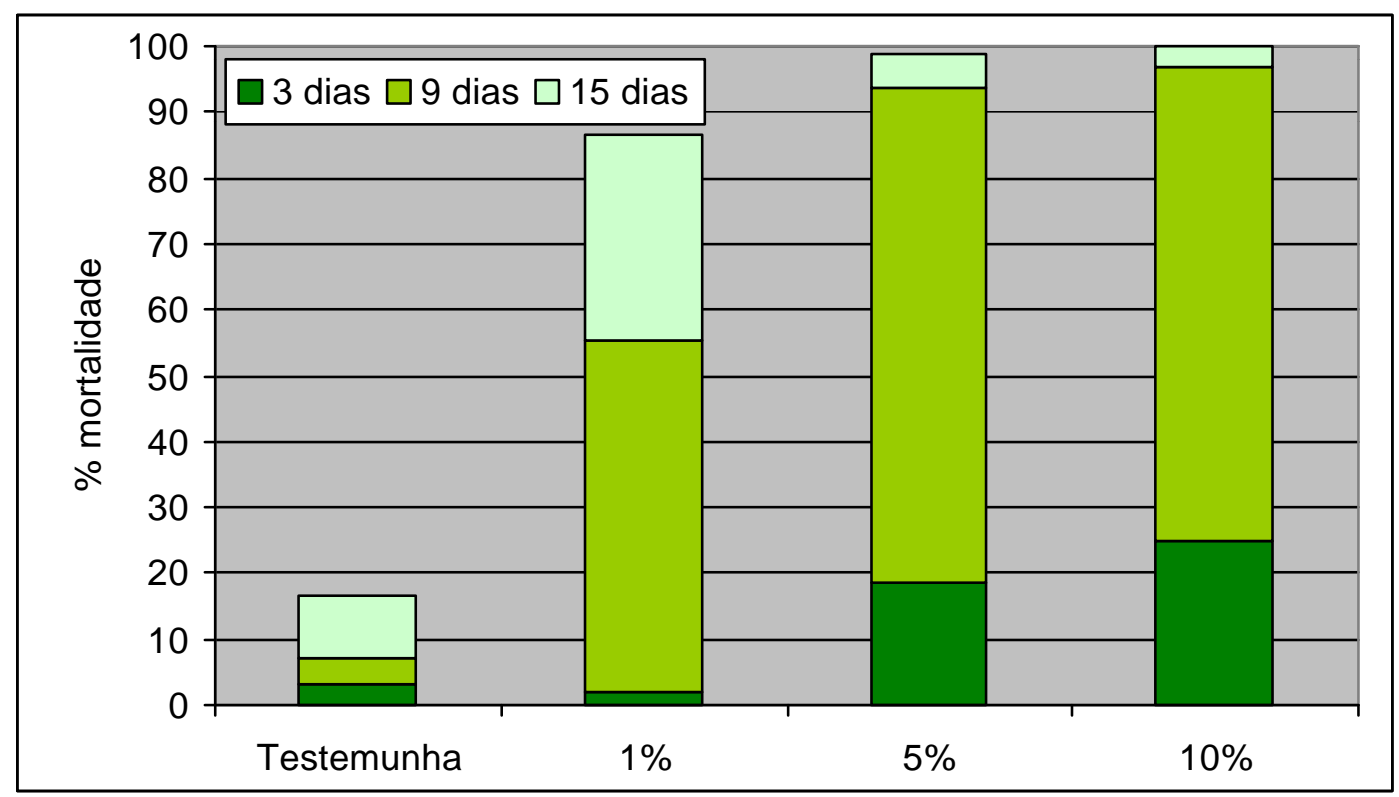

Figura 5 - Mortalidade de adultos de Blattella germanica expostos à superfície contaminada com Metarhizium anisopliae (ESALQ1037) em diferentes concentrações

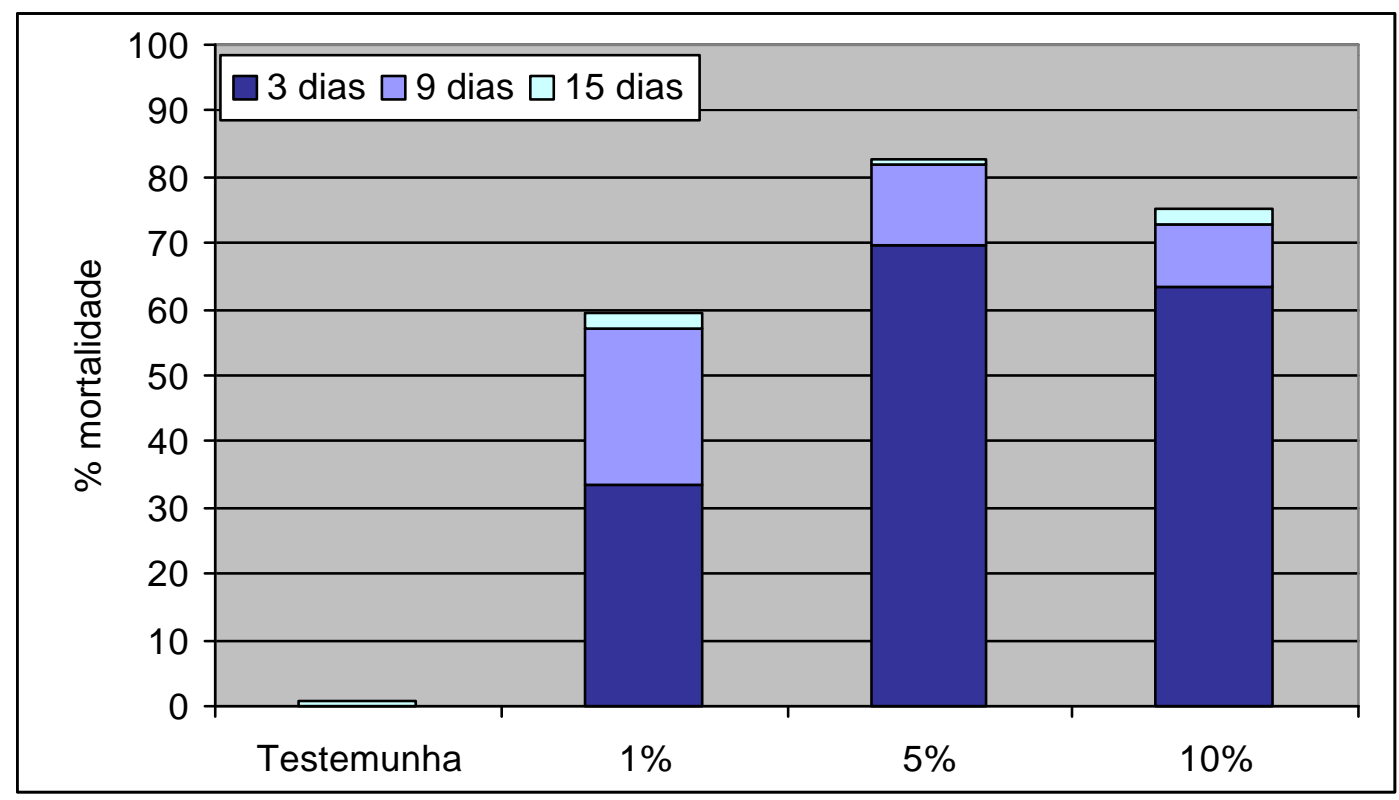

Figura 6 - Mortalidade de ninfas de Blattella germanica expostos à superfície contaminada com Metarhizium anisopliae (ESALQ1037) em diferentes concentrações 
Após 48 horas do início da alimentação dos adultos na isca contaminada, conídios de $M$. anisopliae foram encontrados nas três porções do trato digestivo. $\mathrm{Na}$ região do proctódeu, observou-se uma grande quantidade de conídios aderida à massa fecal na ampola retal (Figura 7). O exame microscópico do material indicou que em nenhuma das três parte do tubo digestivo haviam conídios germinados. Conídios íntegros também foram recuperados em pellets fecais. A liberação de conídios viáveis nas fezes favorece infecções secundárias na colônia. Nesse caso, pellets fecais contaminados e depositados por indivíduos que se alimentaram da isca com o patógeno poderia ser uma fonte de inóculo importante para o desencadeamento de epizootias. Contudo, os conídios presentes no conteúdo interno do trato digestivo não germinaram quando plaqueados em meio de cultura.

A inviabilização dos conídios de $M$. anisopliae no trato digestivo de $B$. germanica pode ter ocorrido por fatores mecânicos ou químicos no processo de digestão do alimento pela barata. Apesar da intensa atividade do proventrículo ou moela, bem desenvolvida e com uma função importante nesse grupo de insetos, esse fator mecânico não parece estar envolvido na inviabilização dos conídios, já que os mesmos não apresentavam sinais visíveis de injúria quando observados ao microscópio óptico. Já fatores químicos, representados pela ação das enzimas produzidas no mesêntero, podem ter contribuído para a inviabilização dos conídios do fungo. Cabe ressaltar, que não foi observado queda na viabilidade dos conídios presentes na isca contaminada armazenada à temperatura ambiente por até 72 horas, e que não passou pelo trato digestivo do inseto. A inviabilização no processo de digestão é também reforçada pela baixa mortalidade dos insetos que se alimentaram na isca contaminada (Tabela 2).

A digestão parcial de conídios de M. anisopliae foi constatada por Lacey et al. (1988) em larvas de Culex quinquefasciatus expostas à suspensão do patógeno na água. Apesar da grande quantidade no trato digestivo das larvas, conídios do fungo não apresentavam germinação quando observados ao microscópio óptico e também não foi observado dano aparente no tecido hospedeiro. Contudo, constatou-se altos índices de mortalidade de larvas em um curto período de tempo, como também observado posteriormente por Alves et al. (2002a). Nesses casos, a morte de larvas está relacionada 
com a ação de toxinas liberadas no processo de digestão dos conídios viáveis. Para $B$. germanica, a possível liberação de toxinas pelo fungo parece não ter efeito imediato na sobrevivência do inseto.

Para os insetos que se alimentaram na isca contaminada, os cadáveres apresentavam crescimento do fungo na cabeça e pernas anteriores, e a morte ocorreu, provavelmente, pela colonização inicial dessas partes ou pela deformação do aparelho bucal com a germinação e penetração dos conídios, levando o inseto à morte por inanição.

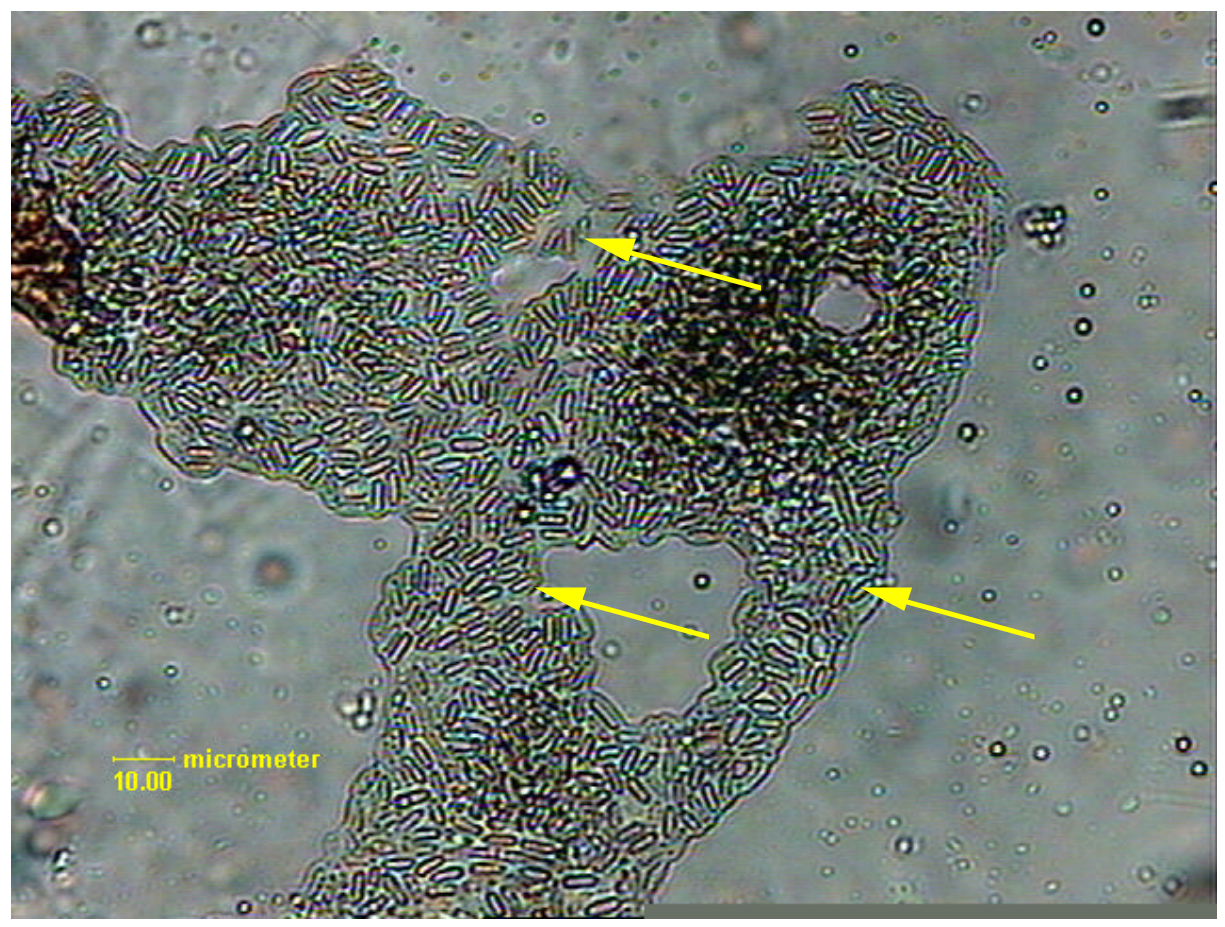

Figura 7 - Conídios inviáveis de Metarhizium anisopliae observados na ampola retal de Blattella germanica após 48 horas da alimentação em iscas contaminadas

$\mathrm{Na}$ infecção via tegumento, o desenvolvimento da doença e conseqüente morte do inseto é dependente do potencial de inóculo, representado pelo número de estruturas do fungo envolvidas no processo infectivo. Esse número, varia em função da espécie e linhagem do fungo e da predisposição ou suscetibilidade do hospedeiro (Alves, 1998). Desse modo, o sucesso no controle de B. germanica com M. anisopliae depende, 
entre outros fatores, do número de conídios aderidos em cada indivíduo (Kaakeh et al., 1997a). Para baratas expostas à superfície contaminada com M. anisopliae, a formulação em pó seco favoreceu a adesão de um número maior de conídios no tegumento, inclusive em locais de difícil limpeza pelo inseto, levando a altos índices de mortalidade. O talco mineral utilizado na mistura possui propriedades físicas que auxiliaram a aderência, atuando como um "carregador" de conídios.

Foi elevado o número de cadáveres em que ocorreu o crescimento e conidiogênese de $M$. anisopliae. Em média, $80 \%$ dos adultos e ninfas mortos nos testes de caminhamento em superfície tratada apresentaram o crescimento do patógeno, em todas as três concentrações. Esse fato, é de grande importância na transmissão do fungo de insetos doentes para outros sadios, ocasionando epizootias em populações de campo e um efeito mais duradouro do tratamento.

A aplicação de conídios de $M$. anisopliae em pó seco é efetiva na obtenção de altos índices de mortalidade de B. germanica, como também observado por Zurek et al. (2002). Contudo, o longo período necessário para se obter tais índices norteia as pesquisas básicas para a busca de agentes que potencializem a ação do patógeno, como a associação com produtos químicos (Kaakeh et al., 1996; Kaakeh et al., 1997a; Pachamuthu et al., 1999; Pachamuthu \& Kamble, 2000). A avaliação de formulações, que proporcionem uma maior aderência do fungo ao inseto e mantenham a alta viabilidade do patógeno em condições de uso e armazenamento, é uma etapa importante no desenvolvimento de produtos comerciais. A segurança dos biopesticidas é uma vantagem que deve ser considerada no desenvolvimento de produtos domissanitários, visando a redução dos riscos dos inseticidas químicos em ambientes domésticos.

\subsection{Conclusões}

- O fungo $M$. anisopliae (ESALQ-1037) é patogênico para ninfas e adultos de $B$. germanica.

- Ninfas de B. germanica são menos sensíveis à infecção pelo patógeno do que aldultos. 
- Iscas atrativas formuladas com conídios de M. anisopliae não causam mortalidade de B. germanica via oral.

- A formulação de M. anisopliae em talco aplicada na superfície de caminhamento dos insetos causa altos índices de mortalidade de adultos e ninfas de B. germanica. 


\title{
4 EFEITO DE ISCAS ATRATIVAS FORMULADAS COM TRIFLUMURON E PYRIPROXIFEN SOBRE NINFAS E ADULTOS DE Blattella germanica (DICTYOPTERA: BLATTELLIDAE)
}

\author{
Autor: ROGÉRIO BIAGGIONI LOPES \\ Orientador: Prof Dr. SÉRGIO BATISTA ALVES
}

\section{Resumo}

A segurança dos inseticidas que regulam o crescimento dos insetos vem despertando o interesse para seu uso no controle de pragas em ambientes urbanos. Avaliou-se o efeito dos inseticidas triflumuron e pyriproxifen na mortalidade de ninfas e na reprodução de adultos de Blattella germanica em condições de laboratório, visando a associação desses produtos com entomopatógenos. A contaminação dos insetos ocorreu pela ingestão de iscas atrativas incorporadas com os produtos, durante um período de 72 horas. $\mathrm{O}$ valor de $\mathrm{CL}_{25}$ após 15 dias obtido para ninfas de 20 a 22 dias de idade tratadas com triflumuron e pyriproxifen foi de $0,19 \%$ e $0,45 \%$ de ingrediente ativo na isca, respectivamente. A mortalidade de ninfas de 35 a 40 dias de idade alimentadas com iscas de triflumuron (1\%) foi de 61,5\%. A maioria dos insetos que sobreviveram $(27,1 \%)$ transformaram-se em adultos. A isca de pyriproxifen $(1 \%)$ causou mortalidade inferior a $8 \%$ para ninfas dessa idade, contudo apenas 6,2\% dos insetos atingiu a fase adulta. Fêmeas virgens não contaminadas produziram, em média, 0,9 ootecas por fêmea com $100 \%$ de viabilidade, obtendo-se 33,8 ninfas por ooteca após 25 dias. Para o inseticida triflumuron o número de ootecas inviáveis (aborto) foi reduzido, contudo o número de descendentes produzidos por ooteca foi de apenas 18,1 ninfas. O número de 
ootecas que não produziram descendentes representou $88,1 \%$ do total de ootecas observadas no tratamento com o pyriproxifen. Apesar dos baixos índices de mortalidade de ninfas, os inseticidas reguladores de crescimento são importantes no controle de colônias de $B$. germanica em ambientes urbanos pelo efeito negativo na reprodução dos adultos e poderiam ser associados com entomopatógenos visando ao controle dessa praga. 


\title{
4 EFFECT OF TRIFLUMURON AND PYRIPROXIFEN TOXIC BAITS ON NYMPHS AND ADULTS OF THE GERMAN COCKROACH Blattella germanica (DICTYOPTERA: BLATTELLIDAE)
}

\author{
Author: ROGÉRIO BIAGGIONI LOPES \\ Adviser: Prof Dr. SÉRGIO BATISTA ALVES
}

Summary

The safety of the insect growth regulators is an interest aspect for their use in urban pest control. It was evaluated the effect of the insecticides triflumuron and pyriproxifen on mortality and reproduction of the German cockroach Blattella germanica in laboratory conditions. The insects were exposed to the insecticide-baits, during a 72-hour period. The $\mathrm{LC}_{25}$ for 20 to 22 days old nymphs treated with triflumuron and pyriproxifen was $0.19 \%$ and $0.45 \%$ (active ingredient) respectively, after a 15 -day period. The mortality of 35 to 40 days old nymphs exposed to the triflumuron-bait $(1 \%)$ was $61.5 \%$, and $27.1 \%$ of the insects became adults. The pyriproxifen-bait (1\%) caused nymph mortality of 35 to 40 days old lower than $8 \%$; however, only $6.2 \%$ of the insects reached the adult stage. Untreated females produced 0.9 ootheca average per individual, with $100 \%$ of viability, and a progeny of 33.8 nymphs per ootheca after 25 -day period. The number of unviable oothecae for the triflumuron-bait was low; however the average number of newly hatched nymphs was only 18.1 per ootheca. The number of deformed and unviable oothecae was $88.1 \%$ in the pyriproxifen-bait treatment. In spite of the low mortality rate of nymphs, the insect growth regulators were effective for the control of the German cockroach colonies and for their negative effect in the reproduction of the insects. These insecticides could be associated with microbial pesticides for a safety and long period control of cockroach colonies. 


\subsection{Introdução}

Devido à crescente preocupação com a segurança dos inseticidas químicos utilizados no controle de pragas urbanas e de problemas relacionados ao desenvolvimento de resistência de insetos a esses produtos, os inseticidas reguladores de crescimento (IRC) receberam, a partir de meados da década de 1970, grande atenção de cientistas e do mercado domissanitário. De modo geral, esse grupo de inseticidas é de baixa toxicidade a vertebrados, como aves e mamíferos. Isso ocorre devido ao seu modo de ação, ligado a regulação da atividade de hormônios que são específicos de artrópodes.

São muitas as pesquisas que comprovam a eficiência da atividade inseticida dos IRC sobre Blattella germanica em laboratório e em campo, tornando esses produtos indicados para a incorporação em programas de controle pragas (Riddiford et al., 1975; Schal \& Hamilton, 1990; Bennet \& Reid, 1995). Dentre os mais estudados estão os inibidores de síntese de quitina (DeMark \& Bennett, 1989; Koehler \& Patterson, 1989; Reid et al., 1992; Aguilera et al., 2001) e os análogos do hormônio juvenil ou juvenóides (Bennett et al., 1986; Brenner et al., 1988; Kramer et al., 1990; Koehler \& Patterson, 1991; Zeman et al., 1992).

A ação dos IRC sobre uma população de baratas é favorecida por algumas características comportamentais desses insetos. O canibalismo, a alimentação de ninfas recém-eclodidas em pellets fecais na colônia e o contato constante entre insetos que permanecem agregados são importantes no efeito letal, em cadeia, desses inseticidas (Silverman et al., 1991; Gahlhoff Jr. et al., 1999; Kopanic \& Schal, 1999; Durier \& Rivault, 2000; Patourel, 2000; Buczkowski \& Schal, 2001).

A exposição a determinado IRC, normalmente não causa efeitos letais imediatos, mas induz anomalias que impedem a sobrevivência ou reprodução em momentos particulares da vida do inseto (Staal, 1975; Das \& Gupta, 1977; Bennett \& Reid, 1995). Os inibidores de síntese de quitina, derivados das benzoilfeniluréias, interferem na biossíntese e deposição da quitina no processo de ecdise, levando ao enfraquecimento do exoesqueleto e, geralmente, a morte do inseto. Já os juvenóides 
causam um desequilíbrio endócrino e distúrbios no desenvolvimento do inseto, o que leva à anormalidades morfológicas e, principalmente, a efeitos deletérios na reprodução.

A contaminação via ingestão é, freqüentemente, utilizada para a avaliação da eficiência dos IRC sobre baratas. Contudo, o tratamento de superfícies também é proposto (Ross \& Cochran, 1991; Kaakeh, et al. 1997b), e nesse caso, a contaminação ocorre por ingestão indireta de resíduos do produto no processo de auto-limpeza do inseto. $\mathrm{O}$ presente estudo teve como objetivo avaliar o efeito dos inseticidas triflumuron e pyriproxifen incorporados à iscas atrativas na mortalidade de ninfas e na reprodução de adultos de B. germanica em condições de laboratório.

\subsection{Material e Métodos}

Os insetos utilizados nos testes foram provenientes de colônias de $B$. germanica estabelecidas em laboratório. As iscas atrativas foram preparadas triturandose a ração de cachorro em um fino granulado e os inseticidas triflumuron (Alsystin 250PM) e pyriproxifen (Cordial 100CE), dissolvidos em $4 \mathrm{~mL}$ de água destilada, foram adicionados à isca nas concentrações desejadas. A mistura prévia dos produtos em água permitiu uma boa homogenização dos inseticidas na ração moída. As iscas da testemunha foram preparadas somente com a ração moída e água. As iscas formuladas permaneceram em câmara de fluxo laminar por 12 horas para secagem. Após esse

período, $0,25 \mathrm{~g}$ do material formulado foi transferido para tubos plásticos $(3 \mathrm{~cm}$ de comprimento e $0,5 \mathrm{~cm}$ de diâmetro) com apenas uma das extremidades abertas.

\subsubsection{Eficiência dos inseticidas triflumuron e pyriproxifen sobre ninfas de Blattella germanica}

Para cada tratamento, cinco grupos de 16 ninfas entre 20 e 22 dias de idade, totalizando 80 insetos, foram separados em copos plásticos com tampa, de acordo com a metodologia já descrita no item 3.2.3. Cada repetição recebeu um tubo plástico da isca formulada que serviu como fonte única de alimento nas primeiras 72 horas. Após esse 
período, os tubos plásticos contendo a formulação foram retirados e oferecido apenas ração de cachorro não contaminada até o final de teste. Além do alimento forneceu-se água durante todo o experimento. Estabeleceu-se para os dois produtos a concentração máxima de $1 \%$ de ingrediente ativo na isca. Considerou-se que concentrações acima desse valor inviabilizariam economicamente a utilização do produto, interferindo ainda na atratividade da isca formulada. A partir da concentração máxima, foram selecionadas em testes prévios concentrações inferiores, espaçadas logariticamente, em que os inseticidas apresentavam alguma atividade sobre o inseto. $\mathrm{O}$ inseticida triflumuron foi testado nas concentrações de $0,03 \%, 0,06 \%, 0,126 \%, 0,25 \%, 0,5 \%$ e $1 \%$ de ingrediente ativo na isca, e a testemunha sem o produto. O inseticida pyriproxifen foi testado nas concentrações de $0,01 \%, 0,025 \%, 0,06 \%, 0,16 \%, 0,4 \%$ e $1 \%$ de ingrediente ativo na isca, além da testemunha.

As avaliações foram realizadas a cada três dias e foi determinada a porcentagem de mortalidade de ninfas nos tratamentos durante um período de 15 dias. Os dados foram submetidos à análise de Probit para obtenção da curva dose resposta e determinação da concentração letal $\left(\mathrm{CL}_{25}\right)$.

\subsubsection{Efeitos subletais dos inseticidas triflumuron e pyriproxifen}

Nessa etapa, os inseticidas foram testados sobre ninfas com 35 a 40 dias de idade, no final do desenvolvimento da fase imatura do inseto, e fêmeas adultas virgens recém emergidas (com até 2 dias). Para obtenção das ninfas e fêmeas adultas de idade determinada, ootecas foram coletadas nos recipientes de criação segundo metodologia já descrita anteriormente (item 3.2.3), e mantidas separadas até a eclosão das ninfas. As ninfas foram criadas até atingirem a idade desejada para os testes. No caso das fêmeas, os insetos foram separados em até 12 horas após emergência, utilizando apenas fêmeas ainda não fecundadas.

Para avaliar os efeitos subletais dos inseticidas sobre ninfas, foram estabelecidas em laboratório colônias contendo 24 insetos, em recipientes circulares de vidro $(30 \mathrm{~cm}$ de altura e $20 \mathrm{~cm}$ de diâmetro) com uma camada de vaselina na borda 
superior interna e uma tampa de tecido de malha fina para evitar a fuga dos insetos. Cada grupo de quatro colônias consistiu em um tratamento (total de 96 ninfas por tratamento), representado pelos inseticidas triflumuron e pyriproxifen, na concentração de $1 \%$ de ingrediente ativo, além da testemunha, que recebeu apenas alimento não contaminado. As iscas formuladas permaneceram nas colônias como única fonte de alimento durante 72 horas. Após esse período os tubos plásticos foram removidos fornecendo-se apenas ração de cachorro até o final do teste. Além do alimento, as colônias receberam um abrigo, formado por um tubo de papelão corrugado de $10 \mathrm{~cm}$ de comprimento, e água durante todo o período experimental. Os recipientes permaneceram em sala climatizada $\left(26 \pm 3^{\circ} \mathrm{C}\right.$ e escotofase de 24 horas), sendo realizadas avaliações a cada cinco dias, durante um período total de 25 dias após a instalação das colônias. Observou-se o número de ninfas mortas, a emergência de adultos e a deformação dos insetos em cada colônia. Os dados foram submetidos à análise de variância e as médias comparadas pelo teste de Tukey $(\mathrm{P}<0,05)$.

$\mathrm{Na}$ determinação do efeito dos inseticidas sobre fêmeas virgens, de modo semelhante ao teste com ninfas, foram estabelecidas colônias contendo 12 fêmeas e 8 machos cada, nos mesmos recipientes já descritos. Os machos foram coletados diretamente nos recipientes de criação, separando-se insetos com maior atividade e mobilidade. Cada grupo de quatro colônias consistiu em um tratamento (total de 48 fêmeas por tratamento), representados pelos inseticidas triflumuron e pyriproxifen, na concentração de $1 \%$ de ingrediente ativo, além da testemunha, que recebeu apenas alimento não contaminado. O tempo de alimentação nas iscas contaminadas, as condições do ensaio e os períodos de avaliação foram os mesmos já descritos para o teste com as ninfas nesse item. Nesse caso, observou-se a mortalidade de fêmeas, o número de ootecas produzidas nas colônias, a deformação de ootecas e o número de descendentes produzidos na primeira geração. Os dados foram submetidos à análise de variância e as médias comparadas pelo teste de Tukey $(\mathrm{P}<0,05)$. 


\subsection{Resultados e Discussão}

\subsubsection{Eficiência dos inseticidas triflumuron e pyriproxifen sobre ninfas de Blattella germanica}

A mortalidade média corrigida (Schneider-Orelli, 1947) de ninfas de $B$. germanica para o inseticida triflumuron variou de $10,1 \%$ a $55,7 \%$ nas concentrações testadas, 15 dias após a exposição ao produto. Já para o inseticida pyriproxifen os valores de mortalidade corrigida obtidos foram inferiores, variando entre 2,5\% a 34,2\% no mesmo período.

$\mathrm{O}$ valor de $\mathrm{CL}_{25}$ obtido para ninfas tratadas com triflumuron foi de $0,19 \%$ de ingrediente ativo, com limites entre $0,11 \%$ e $0,29 \%$ (I.C. $90 \% ; t=7,21 ; \chi^{2}=4,63$ ). No caso do inseticida pyriproxifen, a $\mathrm{CL}_{25}$ foi de $0,45 \%$, duas vezes maior que o triflumuron, com limites entre $0,29 \%$ e $0,75 \%$ (I.C. $90 \% ; t=6,23 ; \chi^{2}=1,14$ ). De acordo com a análise de Probit, rejeitou-se a hipótese das retas serem as mesmas e existe paralelismo entre elas, indicando que a resposta aos produtos são semelhantes, contudo em intensidade diferente (Figura 8 e 9).

Os inibidores de síntese de quitina, a exemplo do triflumuron, interferem na biosíntese e deposição da quitina, atuando em uma etapa importante da vida dos artrópodes, o processo de ecdise. Nessa fase, o inseto troca temporariamente o exoesqueleto, o que permite seu crescimento durante a fase imatura. Observou-se que mais de $85 \%$ dos insetos mortos pelo produto apresentavam-se deformados, em função da deposição irregular da quitina do novo exoesqueleto, ou permaneceram presos ao tegumento antigo (Figura 10A), como também observado por DeMark \& Bennett (1989) e Aguillera et al. (2001) para benzofeniluréias.

A morte dos insetos não ocorreu rapidamente, contudo, após o quinto dia de avaliação foi possível observar efeitos claros da contaminação, como a dificuldade de locomoção e movimentação descoordenada. Para todas as concentrações testadas do triflumuron houve um aumento progressivo do número de ninfas mortas com o passar do tempo. Essa observação coincide com os estudos feitos por Weaver et al. (1984) para o 
mesmo inseto e produto e nas mesmas concentrações de ingrediente ativo. Porém, os autores detectaram índices de mortalidade de ninfas mais elevados em todos os períodos de avaliação coincidentes, atingindo de 90 a $100 \%$ ao final do experimento. Esse fato deve-se, certamente, ao maior tempo de exposição dos insetos à isca contaminada, que foi durante todo o experimento, e ao período mais longo de avaliação, que foi de 4 semanas.

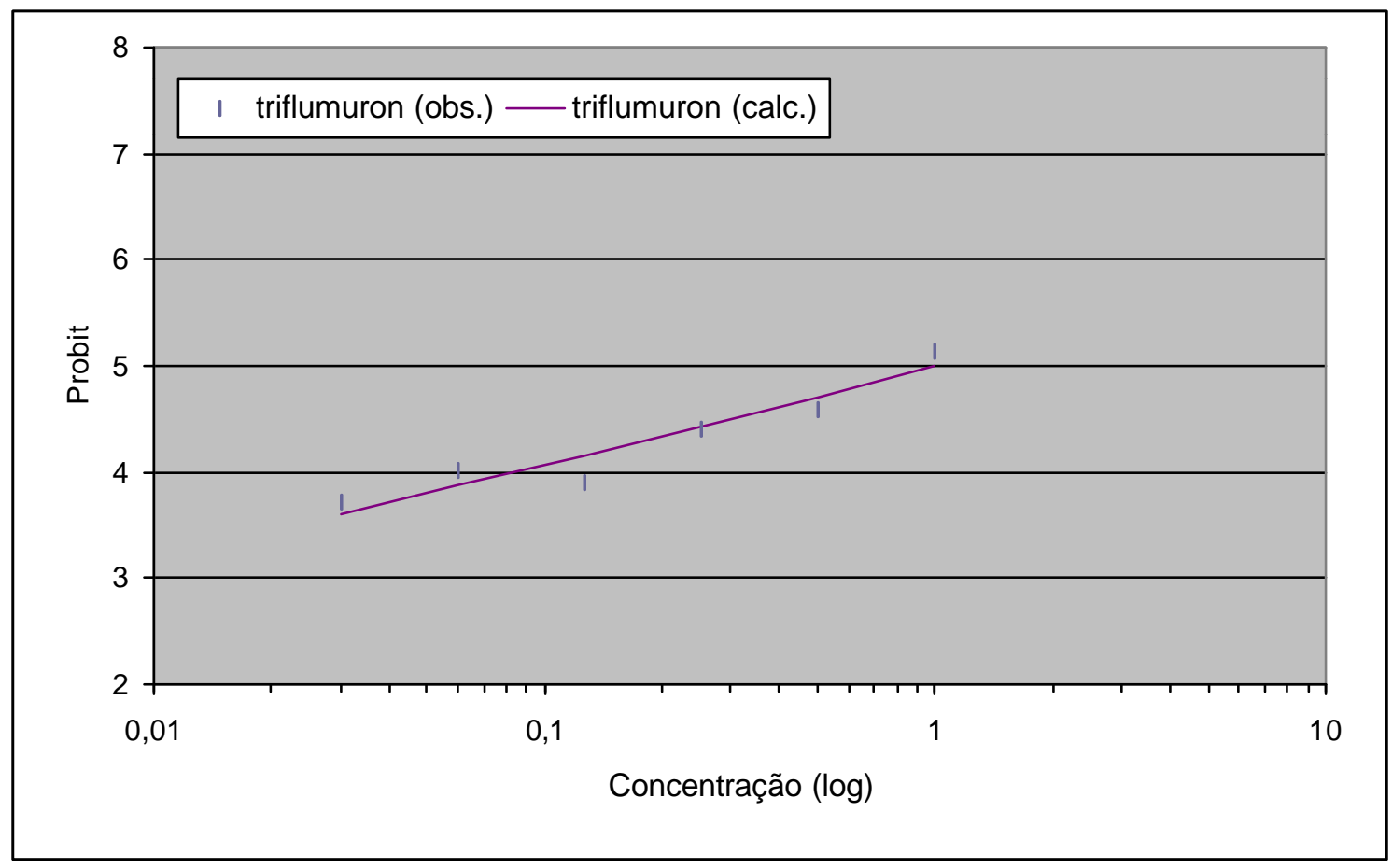

Figura 8 - Curva concentração-resposta expressa pela mortalidade de ninfas de Blattella germanica 15 dias após a alimentação em iscas contaminadas com o inseticida triflumuron. Reta $=$ valores de probit calculado; pontos $=$ valores de probit observados

Os inseticidas juvenóides, como o pyriproxifen, imitam a ação do hormônio juvenil dos insetos, cuja finalidade é impedir a metamorfose precoce. Os insetos contaminados com esses produtos têm a metamorfose afetada, mantendo-se em estágios imaturos, o que leva freqüentemente à morte. Nesse caso, o tempo necessário para a morte do inseto pode ser ainda maior. No teste com o inseticida, o período de avaliação 
de 15 dias foi reduzido para se observar altos índices de mortalidade, embora muitas ninfas apresentaram sintomas característico de contaminação por esse grupo químico, como o escurecimento completo do corpo (Figura 10B) e movimentação descoordenada (King \& Bennett, 1988).

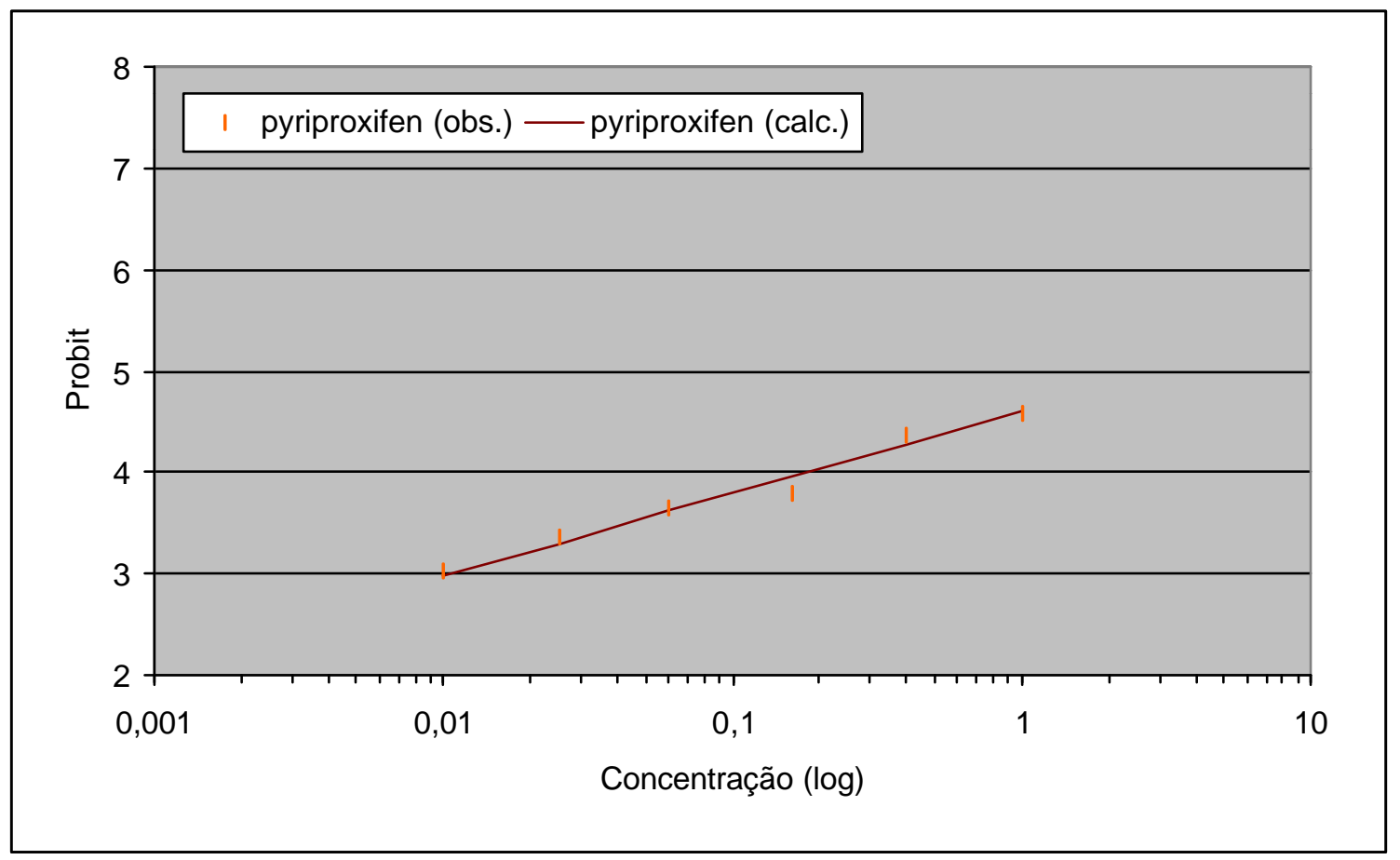

Figura 9 - Curva concentração-resposta expressa pela mortalidade de ninfas de Blattella germanica 15 dias após a alimentação em iscas contaminadas com o inseticida pyriproxifen. Reta $=$ valores de probit calculado; pontos $=$ valores de probit observados

$\mathrm{O}$ efeito dos produtos sobre o inseto ocorre, provavelmente, quando a ninfa ingere uma quantidade mínima do alimento contaminado. Como a exposição das ninfas aos produtos foi de apenas 72 horas, muitos insetos não ingeriram a quantidade suficiente de inseticida e passaram pelo processo de ecdise normalmente, refletindo em baixa mortalidade. A exposição contínua ao inseticida e a ausência de fontes alternativas de alimento geram índices de mortalidade bem mais elevados, como já discutido anteriormente e demonstrado por Weaver et al. (1984). Os valores de concentração 
resposta obtidos em diversos trabalhos com IRC, quando incorporados ao alimento, são muito inferiores aos observados no presente estudo (DeMark \& Bennett, 1989; Reid et al., 1992; Aguilera et al., 2001). Contudo, em todos esses trabalhos, o tempo que os insetos permaneceram alimentando-se da isca contaminada foi bem maior (exposição contínua), geralmente durante todo o estágio ninfal. Deve-se considerar que essa condição não representa, na maioria dos casos, o que ocorre nos ambientes urbanos, onde os insetos encontram, freqüentemente, outras fontes de alimento. Porém, em função do alto poder residual dos produtos químicos em ambientes protegidos, que é o caso de construções em áreas urbanas, o período de alimentação na isca contaminada pode ser superior a 72 horas, aumentando a eficiência do tratamento. Desse modo, a manutenção dos locais tratados com a isca tóxica livre de fontes alternativas de alimento é um procedimento importante a ser adotado em programas de controle de baratas em ambientes urbanos.

Além do tempo de alimentação, a idade das ninfas também interfere na eficiência dos inseticidas, sendo que ninfas dos primeiros estágios são mais sensíveis do que ninfas de último estágio (Koehler \& Patterson, 1989). A ingestão do produto na isca pode ocorrer ao acaso, especialmente em ambientes com abundância de outras fontes de alimento, e pode nem sempre acontecer nas fases mais sensíveis do inseto (DeMark \& Bennett, 1989).
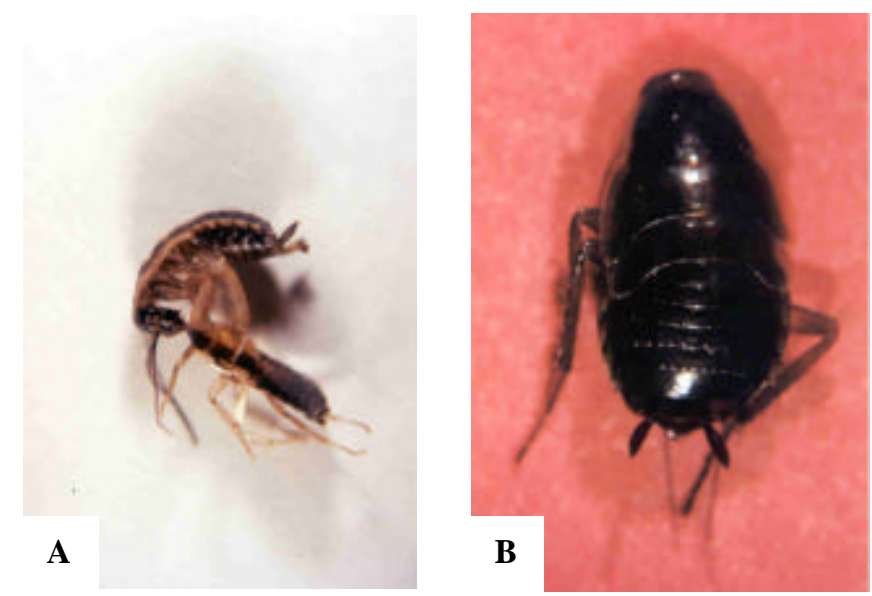

Figura 10 - Ninfas de Blattella germanica com sintomas de contaminação pelos inseticidas triflumuron $1 \%$ (A) e pyriproxifen $1 \%$ (B) 


\subsubsection{Efeitos subletais dos inseticidas triflumuron e pyriproxifen}

Nas colônias de ninfas de último estágio, a mortalidade após um período de 25 dias para o inseticida triflumuron foi de 61,5\%, diferindo dos demais tratamentos (Tabela 4). Apesar de ninfas mais jovens serem mais sensíveis ao produto em comparação a estágios ninfais mais avançados, a média de mortalidade nas colônias foi cerca de 5\% superior à observada no teste de concentração-resposta $(56,2 \%)$, na mesma concentração e com o mesmo tempo de exposição ao alimento contaminado. Essa diferença deve-se ao aumento em 10 dias no período de avaliação no teste realizado em colônias. Ao décimo quinto dia, a mortalidade média de ninfas nesse teste foi de apenas $27,1 \%$, comprovando o maior efeito inseticida sobre estágios imaturos no início do desenvolvimento. Na colônia que não recebeu tratamento algum, a mortalidade foi de apenas 7,3\%, não diferindo do pyriproxifen (7,3\%) (Tabela 4). Nesse caso, a sensibilidade de ninfas mais jovens foi bem superior a de ninfas nos últimos estágios de desenvolvimento, próximo da emergência dos adultos.

Mais de $80 \%$ do total das ninfas na testemunha atingiu a fase adulta após 25 dias, um índice de emergência elevado considerando-se ainda que houve mortalidade de ninfas $(7,3 \%)$ durante o período. Esse valor foi bem superior aos observados nos tratamentos com os inseticidas. A emergência nos tratamentos com triflumuron e pyriproxifen foi de $27,1 \%$ e $6,2 \%$, respectivamente. Mesmo obtendo-se uma variação média de $20 \%$ entre os inseticidas, não foi observado diferença significativa quanto a esse parâmetro. Apesar da baixa atividade do pyriproxifen sobre a mortalidade das ninfas, observou-se uma reduzida taxa de formação de adultos na colônia. Para o inseticida triflumuron, a grande maioria das ninfas sobreviventes se transformou em adultos, embora isso represente menos de 1/3 do total das ninfas no tratamento (Tabela 4 e Figura 11).

Não foi observado deformação dos adultos que não receberam isca formulada com o inseticida. Mais da metade do número de adultos que emergiram no tratamento com triflumuron apresentou deformações. Foi constatada a deformação de adultos quando os insetos apresentavam alterações significativas nas asas ("twisted wings") e/ou 
na coloração do corpo (enegrecimento). Para o inseticida pyriproxifen, esse valor foi bem maior, ou seja, de um total de 6,2\% de insetos que se transformaram em adultos, 5,1\% apresentaram deformação (Figura 11). Contudo, a análise de variância para a porcentagem média de deformação não foi significativa.

Tabela 4. Porcentagem de mortalidade de ninfas, emergência e deformação de adultos de Blattella germanica submetidos ao tratamento com os inseticidas triflumuron e pyriproxifen

\begin{tabular}{ccccccc}
\hline & MORTALIDADE & \multicolumn{2}{c}{ EMERGÊNCIA DE } & \multicolumn{2}{c}{ DEFORMAÇÃO DE } \\
TRATAMENTOS & DE NINFAS $(\%)^{1}$ & INSETOS $(\%)^{1}$ & \multicolumn{2}{c}{ ADULTOS $(\%)^{2}$} \\
\hline testemunha & 7,287 & $\mathrm{a}$ & 81,250 & $\mathrm{a}$ & 0,000 & $\mathrm{ns.}$ \\
triflumuron (1\%) & 61,457 & $\mathrm{~b}$ & 27,082 & $\mathrm{~b}$ & 13,540 & $\mathrm{ns.}$ \\
pyriproxifen (1\%) & 7,292 & $\mathrm{a}$ & 6,250 & $\mathrm{~b}$ & 5,125 & $\mathrm{~ns}$. \\
\hline
\end{tabular}

T'médias seguidas por letras distintas diferem entre si ao nível de significância de 5\% pelo teste de Tukey

${ }^{2}$ não significativo pelo teste de Tukey $(\mathrm{P}>0,05)$

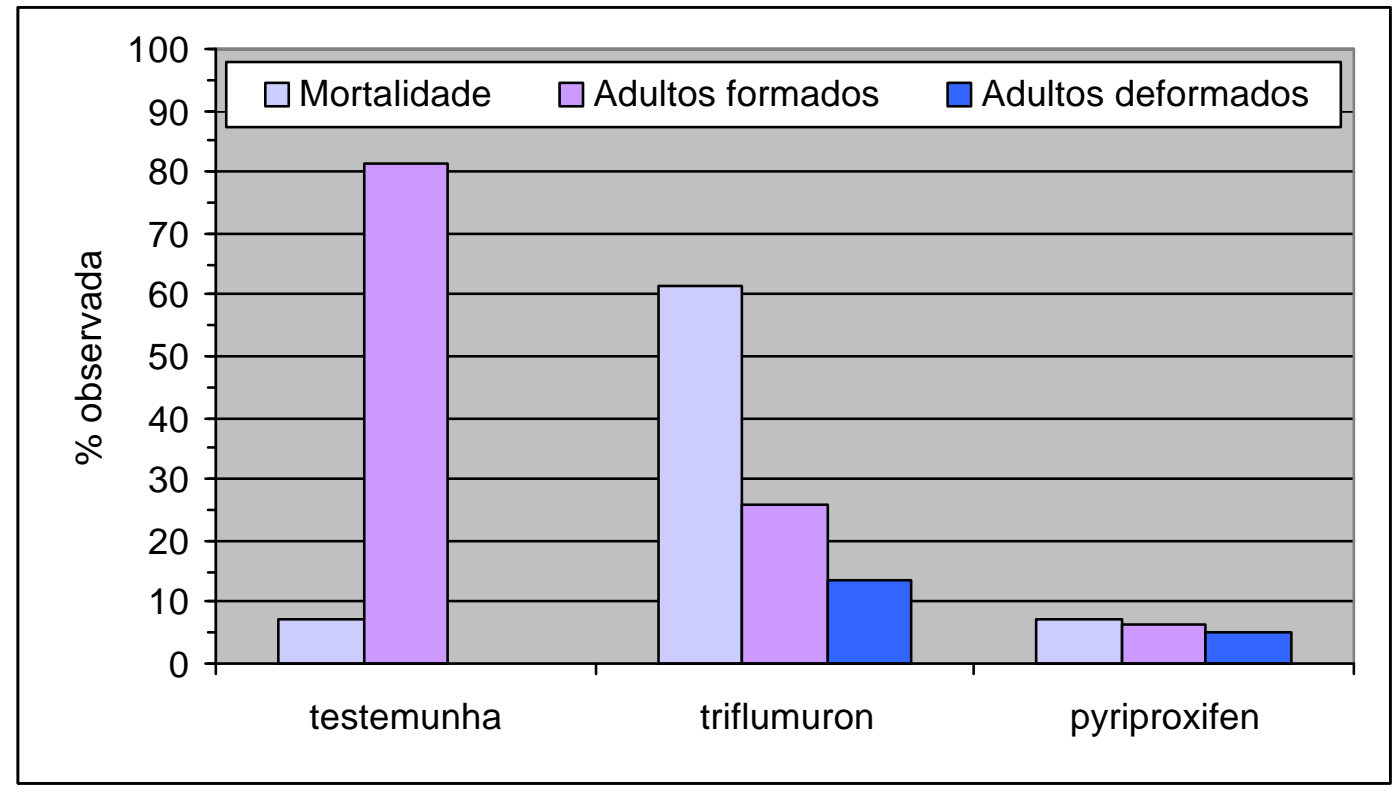

Figura 11 - Porcentagem de mortalidade de ninfas, de emergência e de deformação de adultos de Blattella germanica 25 dias após a alimentação em iscas contaminadas com os inseticidas triflumuron (1\%) e pyriproxifen (1\%) 
Nos testes com fêmeas virgens, em todas as colônias, tanto nas tratadas com os inseticidas quanto na testemunha, observou-se a formação de ootecas, em uma média de 0,9 por fêmea, após um período de 25 dias. Contudo, a análise de variância para o número de ootecas formadas por colônia não foi significativa. Ao contrário de ninfas expostas aos IRC, que podem sofrer alterações fisiológicas e morfológicas interferindo no acasalamento e a geração de ootecas (DeMark \& Bennett, 1989), adultos tratados são capazes de copular normalmente. Desse modo, a produção média de ootecas por colônia foi semelhante nos diferentes tratamentos.

$\mathrm{Na}$ colônia que não recebeu alimento contaminado, todas as ootecas apresentaram-se viáveis, produzindo em média 33,8 ninfas por ooteca. Já para o inseticida triflumuron, o número de ootecas abortadas foi pequeno, não diferindo da testemunha. Nesse caso, o número de descendentes produzidos foi significativamente menor (18,0 ninfas por ooteca), caracterizando a ação do produto na formação dos embriões ou da ooteca (Tabela 5 e Figura 12). O produto afetou a aparência das ootecas inviáveis ou parcialmente viáveis, tornando-as enegrecidas completamente ou em algumas partes, como relatado por Koehler \& Patterson (1989). Segundo Weaver et al. (1984), que também observaram tal efeito, o triflumuron pode produzir alterações no processo de esclerotização e melanização da ooteca.

Tabela 5. Número de ootecas formadas, de abortos e de ninfas por ooteca para fêmeas virgens de Blattella germanica submetidas ao tratamento com os inseticidas triflumuron e pyriproxifen.

\begin{tabular}{|c|c|c|c|c|c|c|}
\hline \multirow{2}{*}{$\begin{array}{c}\text { TRATAMENTOS } \\
\text { testemunha }\end{array}$} & \multicolumn{2}{|c|}{$\begin{array}{l}\text { NÚMERO DE } \\
\text { OOTECAS }^{2}\end{array}$} & \multicolumn{2}{|l|}{$\begin{array}{l}\text { NÚMERO DE } \\
\text { ABORTOS }^{1}\end{array}$} & \multicolumn{2}{|c|}{$\begin{array}{c}\text { NÚMERO DE } \\
\text { NINFAS/OOTECA }\end{array}$} \\
\hline & 10,250 & ns. & 0,000 & $\bar{a}$ & 33,837 & $\mathrm{a}$ \\
\hline triflumuron $(1 \%)$ & 10,750 & ns. & 1,500 & $\mathrm{a}$ & 18,022 & $\mathrm{~b}$ \\
\hline pyriproxifen (1\%) & 10,500 & ns. & 9,250 & $\mathrm{~b}$ & 0,000 & $\mathrm{c}$ \\
\hline
\end{tabular}

${ }_{2}^{1}$ médias seguidas por letras distintas diferem entre si ao nível de significância de 5\% pelo teste de Tukey

2 não significativo pelo teste de Tukey $(\mathrm{P}>0,05)$ 
Para o inseticida pyriproxifen esse efeito foi ainda mais visível. O número de ootecas inviáveis (abortos) por colônia foi de 9,2 diferindo dos demais tratamentos e representando $88,1 \%$ do total de ootecas produzidas nesse tratamento. A inviabilização completa das ootecas pelo pyriproxifen impediu a existência de uma nova geração de ninfas na colônia (Tabela 5 e Figuras 12 e 13). Segundo King \& Bennett (1989), fêmeas tratadas com fenoxycarb e hydroprene normalmente são capazes de produzir ootecas, contudo, o aborto ocorre após poucos dias e as ootecas apresentam-se deformadas ou enrugadas.

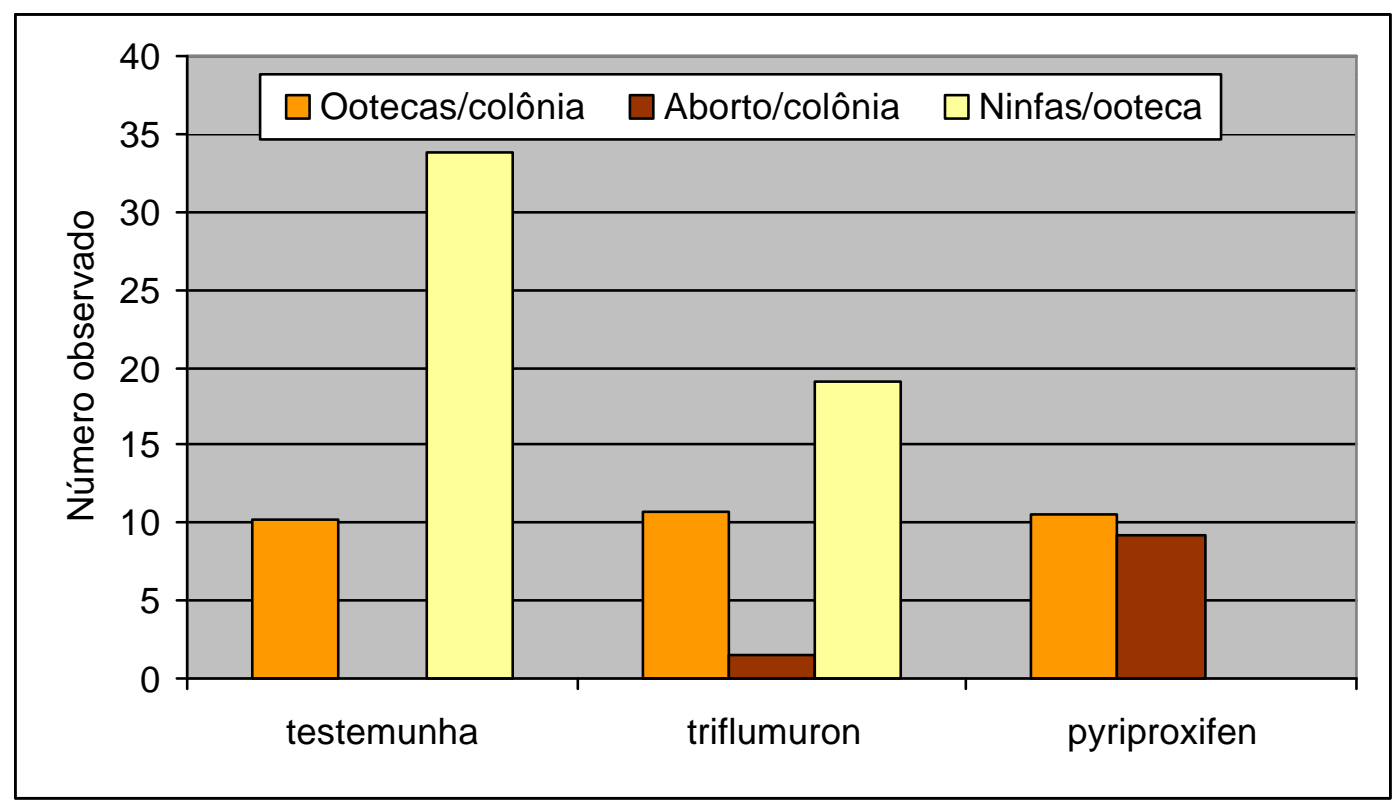

Figura 12 - Número de ootecas e abortos observados por colônia e número de ninfas de Blattella germanica produzidas por ooteca, 25 dias após a alimentação em iscas contaminadas com os inseticidas triflumuron (1\%) e pyriproxifen $(1 \%)$

A esterilização de adultos por inibidores de síntese de quitina não é geralmente aparente. O que pode causar a infertilidade são deformações morfológicas na genitália, principalmente de machos, que ocorre durante a última ecdise quando ninfas são contaminadas (DeMark \& Bennett, 1989). Essas deformações em machos já são comprovadas para ninfas tratadas com hydroprene, um análogo do hormônio juvenil 
(Kramer et al., 1989). Entretanto, efeitos deletérios na reprodução de fêmeas podem também ser observados para as benzoilfeniluréias. Fêmeas expostas à superfície contaminada com lufenuron apresentaram desde redução da viabilidade de ootecas e do número de ninfas produzidas por ooteca, até o aumento do número de abortos, em função da dose e tempo de exposição (Kaakeh et al., 1997b). As fêmeas virgens tratadas com triflumuron produziram ootecas e descendentes, com uma pequena taxa de aborto, apesar da redução do número de ninfas por ooteca quando comparado com adultos não tratados. Nesse caso, a existência de descendentes pode interferir na eficiência do triflumuron em aplicações em campo, pela possibilidade dessa nova geração estabelecerse novamente na área. O monitoramento do número de insetos e determinação da composição da população acaba sendo importante para que outras aplicações atuem sobre essas ninfas, já que o produto tem boa atividade inseticida sobre a fase imatura.

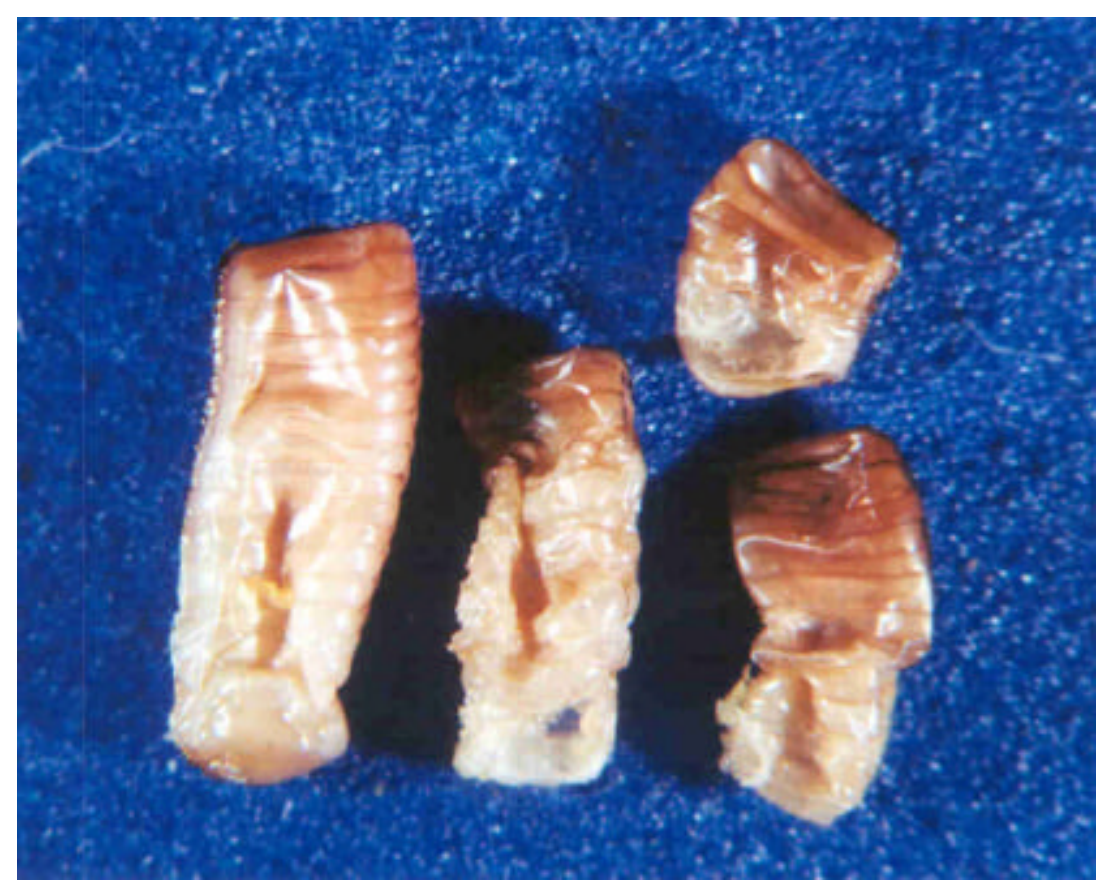

Figura 13 - Ootecas mal formadas e inviáveis (aborto) de Blattella germanica 25 dias após a alimentação de fêmeas virgens em isca contaminada com pyriproxifen (1\%) 
A persistência do hormônio juvenil ou análogo do hormônio juvenil no corpo do inseto, dependendo da dose e tempo de exposição, resulta em um aumento no número de ínstares na fase imatura ou a permanência do inseto em estágios imaturos intermediários inférteis (Dhadialla et al., 1998). As ninfas tratadas com pyriproxifen apresentaram-se ao final do teste com o tegumento completamente escurecido, e muitas dessas, com características morfológicas intermediárias, entre ninfa e adulto (ninfóides). Os ninfóides são indivíduos inférteis e possuem tecas alares dilatadas no mesotórax e um início de formação de asas metatoráxicas (Ross \& Cochran, 1990). Além da indução de deformidades morfológicas em ninfas, os agonistas do hormônio juvenil levam a esterilidade de adultos, como constatado por Brenner et al. (1988) e King \& Bennett (1990) para o inseticida fenoxycarb. Não foi observado um efeito inseticida tão acentuado do pyriproxifen, contudo, a não formação de adultos a partir de ninfas tratadas e a esterilização das fêmeas pode levar a eliminação completa de uma colônia. Por outro lado, a não eliminação imediata das ninfas de uma população, as quais estariam presentes por períodos mais longos em determinado local, pode gerar uma desconfiança de que o tratamento foi ineficiente e acabar levando a resistência ao uso desse produto por profissionais da área.

Em um contexto prático, onde devem ser considerados diversos fatores, como a capacidade de um produto em suprimir rapidamente uma população, sua eficiência a longo prazo e segurança, as características bioecológicas do inseto, entre outros, a estratégia de associação de produtos ou métodos de controle deve ser avaliada. O estudo de produtos e estratégias de utilização, visando cumprir todas as exigências do mercado, certamente é o caminho para o sucesso do controle de $B$. germanica em ambientes urbanos.

\subsection{Conclusões}

- Iscas atrativas formuladas com triflumuron nas concentrações de 0,5 e 1\% de ingrediente ativo, em um período de exposição de 72 horas, causam índices satisfatórios de mortalidede de ninfas de B. germanica. 
- Iscas atrativas formuladas com os inseticidas triflumuron (1\%) e pyriproxifen (1\%) provocam efeitos negativos na reprodução de $B$. germanica.

- Fêmeas virgens expostas à isca atrativa com pyriproxifen (1\%) por um período de 72 horas não produzem descendentes. 


\title{
5 ASSOCIAÇÃO DE Metarhizium anisopliae COM OS INSETICIDAS TRIFLUMURON E PYRIPROXIFEN NO CONTROLE DE COLÔNIAS DE Blattella germanica
}

\author{
Autor: ROGÉRIO BIAGGIONI LOPES \\ Orientador: Prof Dr. SÉRGIO BATISTA ALVES
}

\section{Resumo}

O efeito da associação de Metarhizium anisopliae com formulações dos inseticidas triflumuron e pyriproxifen no controle de populações de Blattella germanica foi avaliado em condições de laboratório e campo. Os inseticidas foram incorporados à isca atrativa na concentração de $1 \%$ de ingrediente ativo e o patógeno aplicado sobre a superfície de caminhamento dos insetos. Foram feitas três aplicações dos tratamentos, com um período de exposição de apenas 72 horas em laboratório. Colônias não tratadas apresentaram cerca de 6,55 vezes incremento no número de insetos em relação à população inicial em um período de 60 dias, com uma média de 233,9 insetos por colônia. A população submetida a aplicação do fungo isoladamente $(0,064 \mathrm{mg}$ de conídios $/ \mathrm{cm}^{2}$ ) atingiu a média de 185,4 insetos no mesmo período, não diferindo da testemunha. As colônias apresentaram um crescimento menor quando submetidas aos inseticidas triflumuron e pyriproxifen, com 60,8 e 81 insetos em média, respectivamente. Os tratamentos em que os inseticidas foram associados ao fungo $M$. anisopliae revelaram os melhores resultados, com populações de 41,8 e 57,7 insetos para triflumuron $+M$. anisolpiae e pyriproxifen + M. anisopliae, respectivamente. Após 50 dias do início do experimento, o consumo de alimento não tratado durante 72 horas foi 
inferior à testemunha nas colônias tratadas com triflumuron e nas duas associações do patógeno com os inseticidas. Duas aplicações da associação do patógeno e de ambos os inseticidas na mesma isca atrativa em uma câmara de infecção eliminou completamente uma população em campo. Estudos mais detalhados sobre como os inseticidas podem interferir no processo de doença pelo fungo no inseto, além de aspectos relacionados à formulação do micoinseticida e da sua contribuição na mortalidade de populações de $B$. germanica em campo são ainda necessários. 


\title{
5 ASSOCIATION OF Metarhizium anisopliae WITH TRIFLUMURON AND PYRIPROXIFEN ON GERMAN COCKROACH Blattella germanica (DICTYOPTERA: BLATTELLIDAE) CONTROL
}

\author{
Author: ROGÉRIO BIAGGIONI LOPES \\ Adviser: Prof Dr. SÉRGIO BATISTA ALVES
}

\section{Summary}

The association of Metarhizium anisopliae with the insecticides triflumuron and pyriproxifen was evaluated for the control of the German cockroach Blattella germanica in laboratory and field colonies. The insecticides were incorporated to attractive baits (1\% active ingredient) and the fungus was applied as a powder formulation on the surface. Laboratory colonies were treated at $5^{\text {th }}, 25^{\text {th }}$ and $45^{\text {th }}$ day, with an exposed period of 72 hours. Untreated colonies presented a 6.55 -fold in the number of insects after a 60-day period, with 233.9 insects average per colony. The colonies treated with the patogen $\left(0.064 \mathrm{mg}\right.$ of conidia $\left./ \mathrm{cm}^{2}\right)$ had an average of 185.4 insects in the same period. The colonies exposed to the insecticides triflumuron and pyriproxifen had an average of 60.8 and 81 insects, respectively. The insecticides and fungus associations presented populations of 41.8 and 57.7 insects for triflumuron $+M$. anisolpiae and pyriproxifen $+M$. anisopliae, respectively. After 50 days, the food consumption in a 72-hour period in the colonies treated with triflumuron and in the two associations was lower as compared to the untreated colonies. Two applications of the fungus associated with a triflumuron+pyriproxifen-bait, in an infection chamber, eliminated a cockroach colony in field. More detailed studies to evaluate the interference of the insecticides in the disease process, caused by M. anisopliae, and aspects related to the fungus formulation and its contribution to the field mortality populations are still necessary. 


\subsection{Introdução}

O controle químico de Blattella germanica em ambientes urbanos consiste em uma prática amplamente difundida no mercado. A grande maioria dos inseticidas sintéticos disponíveis, como os piretróides, carbamatos e organofosforados, são principalmente de ação neurotóxica, sendo aplicados em pulverização, polvilhamento ou iscas atrativas. Em razão de problemas relacionados à resistência de populações aos inseticidas, contaminação do ambiente e alimentos, e intoxicação de pessoas e animais, estudos vêm sendo direcionados ao uso de produtos químicos mais seguros ou de agentes biológicos de controle.

Nos últimos anos os fungos entomopatogênicos, especialmente Metarhizium anisopliae, receberam alguma atenção para seu uso em programas de manejo de pragas urbanas. O produto Bio-Path ${ }^{\mathrm{TM}}$, desenvolvido pela empresa EcoScience Corp. (Worcester, MA) e comercializado nos Estados Unidos para o manejo de B. germanica, consiste em uma cultura de conídios de $M$. anisopliae em uma câmara de infecção. Apesar da comprovada eficiência de alguns isolados de $M$. anisopliae no controle de $B$. germanica, o longo tempo necessário para o patógeno causar altos índices de mortalidade (Kaakeh et al., 1996; Pachamuthu et al., 1999) representa uma limitação para o uso comercial desse patógeno em campo. Esse foi, provavelmente, um dos motivos para a interrupção da comercialização da câmara de infecção Bio-Path ${ }^{\mathrm{TM}}$ nos Estados Unidos.

Uma das opções para aumentar a eficácia dos fungos entomopatogênicos é sua associação com inseticidas químicos compatíveis, buscando-se um efeito aditivo ou sinérgico (Kaakeh et al., 1997a; Pachamuthu et al., 1999; Pachamuthu \& Kamble, 2000; Zurek et al., 2002). Inseticidas neurotóxicos geralmente causam mortalidade em poucas horas, tempo insuficiente para que o fungo também atue sobre o inseto e inviabilizando a associação. O modo de ação dos inseticidas reguladores de crescimento (IRC) favorece sua associação com os fungos que controlam insetos e a baixa toxicidade desses produtos reduz os problemas relacionados à contaminação do ambiente e do homem. A exposição do inseto a determinado IRC, normalmente não causa efeitos letais imediatos, 
mas induz anomalias que impedem sua sobrevivência nos estágios imaturos ou sua reprodução na fase adulta (Staal, 1975; Das \& Gupta, 1977; Bennett \& Reid, 1995). Devido ao efeito mais lento, o inseticida permite que ocorra a infecção da colônia pelo patógeno, viabilizando a ação conjunta dos dois agentes. O hábito de agregação dos insetos favorece a disseminação do fungo na colônia e a contaminação pelo inseticida via canibalismo e alimentação de ninfas recém-eclodidas em pellets fecais (Silverman et al., 1991; Kaakeh et al., 1996; Gahlhoff Jr. et al., 1999; Kopanic \& Schal, 1999; Durier \& Rivault, 2000; Patourel, 2000; Buczkowski \& Schal, 2001). Essa associação ocasionaria um efeito em cadeia e um controle mais rápido e efetivo da população, sendo desejável para o manejo da resistência.

A redução da quantidade de inseticidas e o uso de produtos mais seguros para o controle de baratas em ambientes urbanos pode eliminar os riscos relacionados à contaminação de alimentos e produtos armazenados e à intoxicação de pessoas e animais domésticos. A pesquisa teve como objetivo avaliar a eficácia do fungo $M$. anisopliae aplicado em superfície, associado aos inseticidas triflumuron e pyriproxifen em iscas atrativas, no controle de colônias de B. germanica em condições de laboratório e campo.

\subsection{Material e Métodos}

Os insetos utilizados nos testes foram provenientes de colônias estabelecidas em laboratório. As iscas contaminadas com os inseticidas triflumuron e pyriproxifen foram preparadas seguindo o método descrito no item 4.3. A formulação em pó com o patógeno foi feita misturando-se conídios de $M$. anisopliae em talco mineral na concentração de $1 \%$.

\subsubsection{Avaliação da repelência de conídios de Metarhizium anisopliae (ESALQ-1037) e da formulação pó seco para Blattella germanica}

Para o teste de repelência foi utilizado o sistema de livre escolha, confrontando-se sempre dois tratamentos. Foram utilizadas ninfas de B. germanica entre 
20 e 22 dias de idade e adultos recém emergidos, separados de acordo com o método descrito anteriormente (item 3.2.3). Grupos de 50 insetos (35 ninfas, 5 machos e 10 fêmeas) foram colocados em recipientes de plástico escuro $(20 \mathrm{~cm}$ de diâmetro e $15 \mathrm{~cm}$ de altura) com uma camada de vaselina na borda superior interna e uma tampa de tecido de malha fina para evitar a fuga. Cada recipiente possuía quatro saídas eqüidistantes de 1 cm de diâmetro cada, onde foram conectados por uma das extremidades tubos de plástico escuro de $20 \mathrm{~cm}$ de comprimento. Ao final da outra extremidade, os tubos foram acoplados a copos plásticos transparentes $(6 \mathrm{~cm}$ de altura e $10 \mathrm{~cm}$ de diâmetro) com tampa e contendo no centro $1.550 \mathrm{mg}$ de ração peletizada cada um. Toda a borda lateral dos copos recebeu uma fina camada de vaselina, obrigando as baratas a caminharem no fundo do recipiente para se alimentarem. As passagens entre os tubos plásticos e os copos de alimentação foram fechadas com algodão durante um período de 24 horas visando a aclimatação das colônias. Nesse curto período os insetos permaneceram em jejum. As colônias também receberam um abrigo no recipiente central, formado por um tubo de papelão corrugado de $10 \mathrm{~cm}$ de comprimento, e água durante todo o período experimental.

Foram avaliados três tratamentos ou confrontos, cada um repetido quatro vezes: a) testemunha (sem tratamento algum) $\mathrm{X}$ testemunha; $\mathrm{b}$ ) testemunha $\mathrm{X}$ conídios secos de M. anisopliae ( $5 \mathrm{mg}$ por copo $=0,064 \mathrm{mg} / \mathrm{cm}^{2}$ ); c) testemunha $\mathrm{X}$ formulação pó seco $\left(100 \mathrm{mg}\right.$ da formulação $1 \%$ por copo $\left.=1,27 \mathrm{mg} / \mathrm{cm}^{2}\right)$. Os copos com tratamentos iguais foram posicionados sempre de forma oposta. Após o período de 24 horas de aclimatação as passagens foram abertas. Os recipientes permaneceram em sala climatizada ( $26 \pm 3^{\circ} \mathrm{C}$ e escotofase de 24 horas) e a avaliação da repelência causada pelo patógeno e pela formulação pó seco foi feita indiretamente, determinando-se o consumo médio de ração após 8 dias em cada tratamento. Os dados foram submetidos a uma análise de variância e as médias comparadas pelo teste $\mathrm{T}(\mathrm{P}<0,05)$. 


\subsubsection{Compatibilidade "in vitro" dos inseticidas triflumuron e pyriproxifen com Metarhizium anisopliae (ESALQ-1037)}

Os testes foram conduzidos em placas de Petri, em meio de cultura BDA (1000mL de caldo de 200g de batata; $15 \mathrm{~g}$ de dextrose; $15 \mathrm{~g}$ de ágar; 0,5g de streptomicina), pela adição dos inseticidas reguladores de crescimento triflumuron (Alsystin 250PM) e pyriproxifen (Cordial 100) ao meio de cultura fundido nas concentrações de $0,08 \mathrm{~g}$ de p.c./100mL e $0,075 \mathrm{~mL}$ de p.c./100mL, respectivamente. Após a solidificação do meio de cultura foi feita a inoculação do microrganismo utilizando-se uma alça de platina. Foi utilizado como inóculo uma cultura pura de $M$. anisopliae produzida previamente em meio de cultura BDA e incubada por um período de 6 dias em câmara climatizada $\left(26 \pm 0,5^{\circ} \mathrm{C} ; 12\right.$ horas de fotofase e $70 \pm 10 \%$ UR). A inoculação foi feita em três pontos eqüidistantes por placa, dispostos em triângulo, visando-se evitar o contato entre as colônias após o crescimento. Foram preparadas três placas por tratamento, totalizando nove colônias, contudo, na avaliação foram consideradas apenas as seis colônias (repetições) mais uniformes. As placas foram incubadas em câmara climatizada $\left(26 \pm 0,5^{\circ} \mathrm{C} ; 12\right.$ horas de fotofase e $70 \pm 10 \%$ UR) por 6 dias.

A determinação do efeito tóxico das formulações foi realizada avaliando-se o crescimento vegetativo e a reprodução do entomopatógeno. O crescimento vegetativo foi determinado medindo-se os diâmetros das colônias em dois sentidos ortogonais na superfície do meio de cultura. Para a avaliação da reprodução (conidiogênese), essas colônias foram recortadas, juntamente com o meio de cultura, e transferidas individualmente para tubos de vidro com água destilada estéril + espalhante adesivo (Tween $80^{\circledR}-0,2 \mathrm{~mL} / \mathrm{L}$ ). Os conídios produzidos foram inicialmente removidos da superfície do meio com o auxílio de um pincel e posteriormente homogeneizados em agitador de tubos (2 minutos) e ultrasom (4 minutos). Em seguida, foram preparadas diluições sucessivas das suspensões de conídios e a contagem foi feita câmara de Neubauer. 
A classificação foi realizada considerando-se os valores médios de porcentagem de esporulação e crescimento micelial (vegetativo) das colônias dos fungos, calculando-se os valores percentuais em relação à testemunha (100\%) e aplicando-se, para cada produto estudado, o modelo proposto por Alves et al. (1998). Os resultados de diâmetro e número de conídios produzidos por colônia foram também submetidos à análise de variância e as médias comparadas pelo teste de Tukey $(\mathrm{P}<0,05)$.

\subsubsection{Eficácia de Metarhizium anisopliae (ESALQ-1037) e dos inseticidas triflumuron e pyriproxifen sobre colônias de Blattella germanica em laboratório}

Avaliou-se o efeito de $M$. anisopliae aplicado em superfície, os inseticidas triflumuron e pyriproxifen incorporados à iscas atrativas e a associação do fungo com os inseticidas sobre colônias de B. germanica em laboratório. As colônias foram estabelecidas em recipientes de vidro $(30 \times 14 \times 18 \mathrm{~cm})$ contendo abrigo, água e alimento (ração peletizada). Uma camada fina de vaselina foi passada na borda superior interna e uma tampa de tecido de malha fina foi colocada para evitar a fuga dos insetos. Cada colônia foi composta de 20 ninfas com idade entre 20 e 22 dias, quatro machos e seis fêmeas virgens recém emergidas (método descrito no item 4.2.2), além de 1 fêmea com ooteca já formada coletada diretamente nos recipientes de criação. A proporção de ninfas e adultos utilizada, onde a maior parte dos insetos encontram-se na fase imatura, representa normalmente uma colônia de B. germanica em crescimento (Cornwell, 1968). Cada grupo de quatro colônias consistiu em um tratamento, totalizando 124 insetos.

A aplicação dos tratamentos foi feita em placas plásticas $(10 \mathrm{~cm}$ de diâmetro e $0,5 \mathrm{~cm}$ de altura) com um comedouro central ( $2 \mathrm{~cm}$ de diâmetro e $0,5 \mathrm{~cm}$ de altura). Foram avaliados os tratamentos: a) testemunha; b) M. anisopliae (5mg de conídios secos por placa $\left.=0,064 \mathrm{mg} / \mathrm{cm}^{2}\right) ;$ c) pyriproxifen $(1 \%)$; d) triflumuron $(1 \%)$; e) pyriproxifen + M. anisopliae; f) triflumuron $+M$. anisopliae. Nos tratamentos com o patógeno, os conídios foram espalhados de forma homogênea com o auxílio de um pincel em toda a superfície da placa, formando uma barreira obrigatória para alimentação dos insetos no 
comedouro central. No caso dos tratamentos com os inseticidas, as iscas contaminadas $(2 \mathrm{~g})$ foram colocadas no comedouro. Para testemunha apenas alimento não contaminado foi fornecido nas placas. Os tratamentos foram realizados em três períodos, aos 5,25 e 45 dias após o estabelecimento das colônias. Cada período de exposição aos tratamentos foi de apenas 72 horas, fornecendo-se em seguida alimento sem tratamento algum.

Os recipientes permaneceram em sala climatizada $\left(26 \pm 3^{\circ} \mathrm{C}\right.$ e escotofase de 24 horas) durante todo o período experimental de 60 dias. Ao final desse período, foi avaliado o número médio de ninfas e adultos nos diferentes tratamentos e ao $50^{\circ}$ dia o consumo médio de ração pelas populações em um intervalo de 96 horas. Os dados foram submetidos à análise de variância e as médias comparadas pelo teste de Tukey $(\mathrm{P}<0,05)$.

\subsubsection{Avaliação da câmara de infecção Myco-IRC no controle de uma colônia de Blattella germanica em campo}

O teste de campo foi conduzido em duas residências não habitadas localizadas na Fazenda Areão (propriedade da ESALQ/USP) em Piracicaba-SP, no período de 13 de outubro de 2003 a 28 de fevereiro de 2004. Para cada residência foi selecionado um único cômodo de cerca de $10 \mathrm{~m}^{2}$. As portas e janelas dos cômodos foram completamente isoladas com filme plástico e fita adesiva para evitar a fuga dos insetos. Em todas as paredes, a uma altura de dois metros do chão, foram presas duas faixas de plástico com 5 $\mathrm{cm}$ de largura cada e distanciadas $10 \mathrm{~cm}$ entre si. A primeira recebeu uma fina camada de vaselina e a segunda uma camada de cola adesiva, controlando a saída dos insetos pelo forro. Na única porta de acesso aos cômodos, as frestas laterais e inferiores foram também fechadas com fita adesiva pelo lado externo.

Em cada cômodo descrito acima foi liberada uma população de $B$. germanica composta por 310 indivíduos, sendo 200 ninfas, 40 machos e 70 fêmeas, 10 dessas com ootecas formadas. Os insetos foram separados diretamente dos recipientes de criação e colocados em uma caixa de papelão $(10 \times 15 \times 5 \mathrm{~cm})$ com dois orifícios de $2 \mathrm{~cm}$ de diâmetro cada, fechadas com uma rolha, formando assim a colônia primária. A colônia

foi colocada no centro do cômodo e os orifícios destampados, permitindo o livre trânsito 
dos insetos. Duas fontes de água ficaram disponíveis durante todo o experimento, posicionadas ao lado da colônia e em um dos cantos dos cômodos. Uma fonte de alimento, constituída de um comedouro com ração peletizada, também permaneceu disponível durante o teste, exceto nos dias do tratamento.

A partir do experimento da associação dos inseticidas com $M$. anisopliae sobre colônias em laboratório e da análise dos resultados, foi desenvolvido especialmente para o teste em campo a câmara de infecção Myco-IRC. Essa câmara consiste de dois módulos circulares sobrepostos. O módulo inferior é formado por uma placa (90mm de diâmetro e $8 \mathrm{~mm}$ de altura) contendo na parte central um conjunto composto de um cilindro ( $25 \mathrm{~mm}$ de diâmetro e $50 \mathrm{~mm}$ de altura) sobre uma outra placa de menor diâmetro ( $35 \mathrm{~mm}$ de diâmetro e $4 \mathrm{~mm}$ de altura). $\mathrm{O}$ cilindro central possui oito orifícios circulares na lateral inferior e uma tampa na abertura superior para introdução do alimento. O conjunto funciona como um comedouro para os insetos. O módulo superior é formado por uma placa de diâmetro um pouco inferior que a primeira $(88 \mathrm{~mm}$ de diâmetro e $12 \mathrm{~mm}$ de altura), com um orifício central de diâmetro igual ao cilindro do módulo inferior. A câmara de infecção é fechada encaixando-se a placa do módulo superior na posição invertida sobre a placa do módulo inferior. Quatro orifícios eqüidistantes de $5 \mathrm{~mm}$ de diâmetro na lateral dos módulos compõem as vias de acesso à câmara. A rotação do módulo superior permite a abertura ou fechamento das entradas, ou seja, a câmara encontra-se aberta quando ocorre a coincidência dos orifícios dos dois módulos (Figura 14).

A câmara de infecção Myco-IRC permite a aplicação simultânea do fungo $M$. anisopliae via caminhamento e dos inseticidas reguladores de crescimento via alimento contaminado. O preparo da câmara foi feito espalhando-se $100 \mathrm{mg}$ de conídios secos de M. anisopliae na placa do módulo inferior $\left(=1,27 \mathrm{mg}\right.$ de conídios $\left./ \mathrm{cm}^{2}\right)$ e colocando-se no cilindro de alimentação $2 \mathrm{~g}$ de isca contaminada pelos inseticidas triflumuron (1\%) e pyriproxifen (1\%). Um cômodo recebeu a câmara Myco-IRC preparada com o patógeno e os inseticidas e o outro cômodo consistiu na testemunha (câmara Myco-IRC somente com alimento). As câmaras foram abertas somente no momento da aplicação, permitindo o acesso das baratas. O mecanismo de abertura a fechamento dos orifícios laterais de 
acesso também evita a saída dos conídios do interior da Myco-IRC, protegendo a pessoa que a manipula da exposição ao fungo.

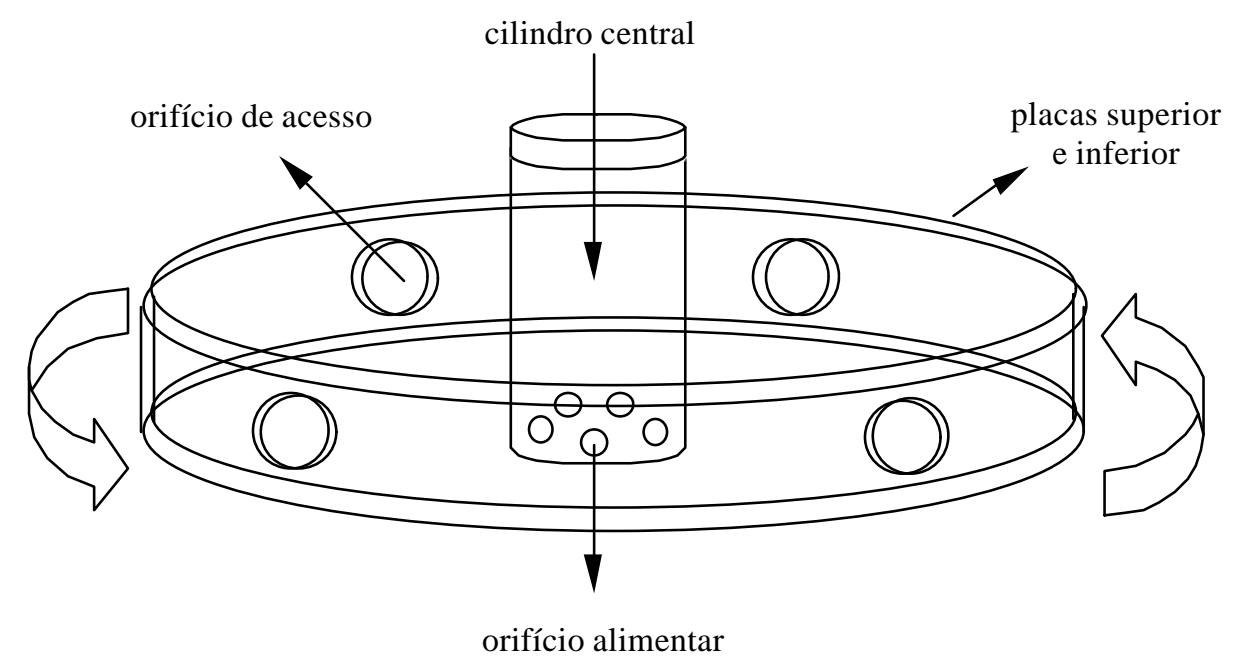

Figura 14 - Modelo esquemático da câmara de infecção Myco IRC utilizada no teste de controle de Blattella germanica em campo

Foram realizadas duas aplicações, após 15 e 40 dias da liberação dos insetos, quando a fonte de alimento foi removida e a câmara de infecção colocada no local correspondente. A exposição aos tratamentos foi de apenas 72 horas, após esse período às câmaras de infecção foram retiradas e colocado novamente a fonte de alimento. Para as duas aplicações foi avaliado o consumo das iscas na câmara de infecção nos dois tratamentos. Foram também feitas quatro avaliações por meio da captura dos insetos em cartões adesivos $\left(75 \mathrm{~cm}^{2}\right)$, após $28,50,88$ e 110 dias da liberação dos insetos. Cinco cartões tipo armadilha contendo $1 \mathrm{~g}$ de isca atrativa no centro foram distribuídas de forma eqüidistante no chão e rente as paredes dos cômodos. As armadilhas permaneceram no local por 72 horas e após esse período foi contado o número de adultos e ninfas capturados nos cartões dos dois tratamentos. Após um período final de 140 dias, as colônias foram fechadas, recolhidas e avaliadas quando ao tamanho e composição da população. 


\subsection{Resultados e Discussão}

\subsubsection{Avaliação da repelência de conídios de Metarhizium anisopliae (ESALQ-1037) e da formulação pó seco para Blattella germanica}

O consumo médio de alimento foi igual quando nenhum dos recipientes recebeu tratamento, evidenciando que apesar do hábito gregário das baratas não existiu preferência a determinado sítio. Quando confrontou-se recipientes tratados com conídios de $M$. anisopliae e recipientes sem tratamento algum o consumo médio de alimento também foi semelhante. Para os três confrontos avaliados no sistema de livre escolha foi observado o efeito de repelência somente para a formulação pó seco. O consumo médio de ração foi $37,6 \%$ inferior nos recipientes tratados com a formulação pó seco $(359,4 \mathrm{mg})$ quando comparado com os recipientes sem tratamento algum (575,8mg) (Tabela 6).

Tabela 6. Consumo de alimento (mg) por ninfas e adultos de Blattella germanica submetidos ao teste de livre escolha para superfícies tratadas com Metarhizium anisopliae

\begin{tabular}{ccc}
\hline TRATAMENTOS & CONSUMO $(\mathrm{mg})$ & \\
\hline Sem tratamento & 447,688 & $\mathrm{a}$ \\
Sem tratamento & 432,625 & $\mathrm{a}$ \\
Sem tratamento & 471,525 & $\mathrm{a}$ \\
M. anisopliae $\left(0,064 \mathrm{mg} / \mathrm{cm}^{2}\right)$ & 468,625 & $\mathrm{a}$ \\
Sem tratamento & 575,775 & $\mathrm{a}$ \\
Formulação pó seco $1 \%\left(1,27 \mathrm{mg} / \mathrm{cm}^{2}\right)$ & 359,437 & $\mathrm{~b}$ \\
\hline
\end{tabular}

Medias seguidas por letras distintas diferem entre si ao nivel de 5\% de probabilidade

A repelência ou não preferência dos insetos por locais tratados com a formulação pode ser considerada sob dois aspectos: um estímulo químico causado pelo patógeno ou um efeito físico da formulação pó seco. No primeiro caso, insetos sociais como formigas e cupins são capazes de identificar microrganismos invasores presentes 
em suas colônias ou contaminando os indivíduos. Jaccoud et al. (1999) observaram que em ninhos de Atta sexdens rubropilosa tratados com M. anisopliae em laboratório ocorreu uma rápida resposta de limpeza das formigas, as quais removeram periodicamente conídios do patógeno e cadáveres infectados da colônia. Em condições naturais as formigas freqüentemente alteram seu comportamento de forrageamento e sua atividade em determinados sítios com o objetivo de evitar microrganismos ou agentes invasores (Machado et al, 1988; Silva \& Diehl-Fleig, 1988; Diehl-Fleig \& Lucchese, 1991; Arismendy \& Peralta, 2002). Resposta semelhante ocorre com os cupins, que por meio do comportamento de limpeza entre indivíduos e pelo bloqueio físico de galerias contaminadas se protegem da ação de entomopatógenos. Agentes estressores, como inseticidas químicos, podem causar uma alteração no comportamento dos indivíduos aumentando a eficiência dos microrganismos (Boucias et al., 1996; Moino Jr. \& Alves, 1998; Neves \& Alves, 1999; Rosales, 2001).

Apesar do hábito gregário, as baratas não formam uma colônia socialmente organizada e parecem não possuir essa capacidade de detectar pequenas quantidades do microrganismo indesejável. Tal efeito fica evidente quando comparamos o confronto entre a testemunha e a superfície tratada apenas com os conídios de $M$. anisopliae. Nesse caso, o consumo médio de alimento pelos insetos nos copos tratados com o fungo (468,6mg) foi igual ao consumo nos copos da testemunha $(471,5 \mathrm{mg})$, ou seja, a presença do patógeno não afetou o comportamento alimentar dos insetos.

No que diz respeito ao efeito físico, notou-se claramente um estímulo negativo da formulação pó seco no comportamento alimentar da população, como já descrito. Nesse caso, a quantidade de conídios utilizada na formulação foi cinco vezes inferior a do tratamento apenas com $M$. anisopliae, contudo, associada ao talco mineral, que correspondeu a $99 \%$ do total aplicado. Como o patógeno não interfere no comportamento do inseto, a redução do consumo ocorreu, provavelmente, pela presença do inerte na superfície de caminhamento dos copos de alimentação. Durante a condução dos ensaios foi observada uma alteração no modo de caminhar dos insetos quando expostos à superfície tratada com a formulação, os quais apoiavam-se apenas nos últimos tarsômeros, visando distanciar o corpo da superfície. 
Desse modo, a composição de uma formulação pó seco para aplicação em superfície é importante e deve ser considerada no desenvolvimento de um produto que utilize esse fungo. Como M. anisopliae atua por contato, a quantidade de conídios que se adere ao indivíduo é determinante na ocorrência da doença e morte do inseto (Kaakeh et al., 1996; Kaakeh et al., 1997a), e isso pode ser diretamente influenciado pelas características da formulação. A exposição forçada de adultos e ninfas de B. germanica à formulação pó seco causou altos índices de mortalidade, como descrito no item 3.3.2. O talco inerte atuou como um carregador de conídios, aumentando a contaminação de partes do corpo de difícil limpeza pelo inseto. Contudo, em condições de livre escolha, a mesma formulação causou a repelência dos insetos por superfícies tratadas, como demonstrado no presente teste.

\subsubsection{Compatibilidade "in vitro" dos inseticidas triflumuron e pyriproxifen ao fungo Metarhizium anisopliae (ESALQ-1037)}

Os produtos Alsystin 250PM e Cordial 100 causaram inibição parcial do crescimento vegetativo e da conidiogênese do fungo. O diâmetro médio das colônias do fungo sobre o meio com os inseticidas triflumuron e pyriproxifen foi de 15,0 e 11,4mm, uma redução de cerca de 32 e $48 \%$ em relação à testemunha, respectivamente. O mesmo comportamento de inibição foi também observado na reprodução do fungo, com reduções na produção de conídios de cerca de $46 \%$ para o triflumuron $\left(2,4 \times 10^{8}\right.$ conídios/colônia) e $66 \%$ para o pyriproxifen $\left(1,5 \times 10^{8}\right.$ conídios/colônia) em comparação com as colônias que não foram submetidas a nenhum tratamento. De acordo com o modelo proposto por Alves et al. (1998), que baseia-se nos valores percentuais médios de esporulação e crescimento micelial das colônias com relação à testemunha, os produtos Alsystin 250PM e Cordial 100 são classificados como moderadamente tóxico e tóxico para M. anisopliae, respectivamente (Tabela 7). 
Tabela 7. Toxicidade dos inseticidas triflumuron e pyriproxifen para o fungo Metarhizium anisopliae (ESALQ-1037)

\begin{tabular}{|c|c|c|c|c|}
\hline PRODUTO & I.A. $^{2}$ & DIÂMETRO DA & $\mathrm{N}^{0}$ DE CONÍDIOS & VALOR \\
\hline COMERCIAL (p.c.) & & COLÔNIA $(\mathrm{mm})^{1}$ & POR COLÔNIA $^{1}$ & $\mathrm{DE} \mathrm{T}^{3}$ \\
\hline $\begin{array}{c}\text { Testemunha } \\
\text { (sem tratamento) }\end{array}$ & - & $22,08 \mathrm{a}$ & $4,53 \times 10^{8} \mathrm{a}$ & - \\
\hline $\begin{array}{l}\text { Alsystin } 250 \mathrm{PM} \\
(0,08 \mathrm{~g} / 100 \mathrm{~mL})\end{array}$ & triflumuron & $15,00 \quad b$ & $2,43 \times 10^{8} \quad b$ & 56,83 \\
\hline $\begin{array}{c}\text { Cordial } 100 \\
(0,075 \mathrm{~mL} / 100 \mathrm{~mL})\end{array}$ & pyriproxifen & 11,42 & $1,50 \times 10^{8}$ & 37,00 \\
\hline
\end{tabular}

A toxicidade de produtos químicos para fungos entomopatogênicos pode estar relacionada, principalmente, à molécula ou ingrediente ativo, à componentes da formulação e a dose de exposição (Alves et al., 1998; Alves et al., 2000; Tamai et al., $2002 b$ ). Esses ingredientes podem atuar isoladamente ou em conjunto para produzir a ação fungicida, inviabilizando o patógeno, ou pelo efeito fungistático, inibindo ou retardando seu crescimento.

No presente estudo, a estratégia de associação utilizada apresenta uma seletividade espacial, ou seja, o microrganismo não está diretamente exposto ao inseticida. O fungo M. anisopliae atua principalmente por contato, com uma baixa atividade quando ingerido pelo inseto (item 3.3.2), e foi aplicado sobre a superfície de caminhamento das baratas. Os inseticidas triflumuron e pyriproxifen possuem ação de ingestão, por isso foram associados à iscas atrativas. Desse modo, o produto químico ocupa um espaço (isca atrativa) onde o conídios do fungo não estão presentes, não ocorrendo a interferência negativa de um sobre o outro.

É importante considerar também que pode ocorrer uma interação negativa ou positiva entre o inseticida e $M$. anisopliae no corpo do inseto, após a ingestão da isca e da penetração e início da colonização pelo patógeno. O conhecimento da toxicidade dos 
produtos para os fungos fornece subsídios para se determinar qual o tipo de associação mais adequada.

\subsubsection{Eficácia de Metarhizium anisopliae (ESALQ-1037) e dos inseticidas triflumuron e pyriproxifen sobre colônias de Blattella germanica em laboratório}

Colônias de $B$. germanica que não receberam tratamento apresentaram um crescimento de cerca de 6,55 vezes no período de 60 dias, atingindo em média 233,9 insetos por colônia. Em virtude do resultados observados no teste de repelência, o tratamento das colônias de $B$. germanica com $M$. anisopliae foi feito apenas com conídios, na dose de $0,064 \mathrm{mg} / \mathrm{cm}^{2}$ ou $5 \mathrm{mg}$ por placa. Nesse caso, observou-se um crescimento da população um pouco menor, atingindo em média 185,4 insetos por colônia no mesmo período, porém não diferindo da testemunha. A baixa eficácia do tratamento com o patógeno ocorreu, provavelmente, pela pequena quantidade de inóculo empregada. Nessas condições, sem a exposição forçada, a adesão dos conídios no corpo dos insetos foi provavelmente restrita apenas às regiões das pernas. Avaliando-se o consumo médio de alimento nas colônias tratadas com $M$. anisopliae, constatou-se que o patógeno não causou repelência dos insetos, já que o peso consumido $(843,6 \mathrm{mg})$ foi estatisticamente igual ao da testemunha (1086,0mg) (Tabela 8). Quantidades maiores do patógeno ou formulações não repelentes devem ser empregadas, já que o número de esporos que se aderem ao corpo do inseto é importante no desencadeamento da doença fúngica, como já discutido anteriormente.

As colônias apresentaram um crescimento menor que a testemunha quando submetidas ao inseticida triflumuron, com 60,8 insetos em média ao final do período experimental. As benzoifeniluréias atuam principalmente sobre as ninfas, levando o inseto à morte por ocasião da ecdise (DeMark \& Bennett, 1989; Koehler \& Patterson, 1989; Reid et al., 1992; Aguilera et al., 2001). Conforme descrito no item 4.3.1, as ninfas mortas apresentavam-se deformadas ou presas ao tegumento antigo, principalmente pelas pernas. Poucos insetos atingiram a fase adulta, o que levou à 
redução do número de machos e fêmeas em comparação com a composição inicial da colônia. Entretanto, os adultos remanescentes foram capazes de se reproduzir estabelecendo uma população média de 56,75 ninfas ao final de 60 dias. O reflexo da pequena população nas colônias foi visível no consumo de alimento $(182,03 \mathrm{mg})$, inferior ao da testemunha e do tratamento com M. anisopliae (Tabela 8).

Semelhante ao que ocorreu com o triflumuron, o inseticida pyriproxifen aplicado isoladamente também causou a redução do crescimento das colônias e do consumo de alimento. A população de ninfas atingiu em média 81 indivíduos e a de adultos chegou a apenas 0,41 indivíduos (Tabela 8). O efeito do inseticida sobre as ninfas foi visível, onde $100 \%$ das ninfas vivas apresentavam-se com o corpo completamente escurecido (King \& Bennett, 1988). O inseticida juvenóide afeta a metamorfose das ninfas, impedindo que o inseto atinja a fase adulta e se reproduza, regulando assim a população no campo.

Os tratamentos em que os inseticidas reguladores de crescimento foram associados ao fungo $M$. anisopliae revelaram os melhores resultados de controle da evolução populacional em laboratório ao final do período experimental. Para triflumuron + M. anisopliae, a população atingiu em média 41,76 insetos e um consumo de alimento inferior a 4mg por colônia. No caso do pyriproxifen $+M$. anisopliae, a população foi de apenas 57,75 insetos, sem a presença de adultos, e o consumo foi em média 194,92mg por colônia (Tabela 8). Apesar da maior redução do número de insetos e do consumo de alimento, para os dois produtos não foi observada diferença estatística entre a aplicação dos inseticidas isoladamente ou em associação com o patógeno. $\mathrm{O}$ baixo potencial de inóculo e o curto período de exposição não forçada (períodos de 72 horas) da população ao tratamento foram provavelmente os fatores limitantes no desencadeamento da doença.

Zurek et al. (2002) observaram uma interação sinérgica entre o ácido bórico e o fungo M. anisopliae. A combinação do inseticida inorgânico com o entomopatógeno resultou em mortalidade entre 40 e $45 \%$ superior aos tratamentos aplicados isoladamente. Os autores sugerem que baixas concentrações do inseticida aumentam a atividade patogênica do fungo, seja por danos físicos no aparelho digestivo e na 
alteração das condições de pH da hemolinfa que facilitem a infecção, ou comprometendo a resposta imunológica do inseto. Efeito aditivo foi também observado por Kaakeh et al. (1997a) para o nicotinóide imidacloprid e Pachamuthu \& Kamble (2000) para os organofosforados chlorpyrifos e propetamphos e o piretróide cyfluthrin, quando associados ao entomopatógeno. Em todos os casos, os insetos foram expostos à grandes quantidades do patógeno, ocasionando a doença e um efeito visível na porcentagem de mortalidade.

Os cadáveres coletados ao final do experimento não apresentaram o crescimento do patógeno nos tratamentos em que foi usado $M$. anisopliae isoladamente ou em associação com os inseticidas. A razão mais provável baseia-se no fato de não ter ocorrido normalmente a evolução da doença no inseto, justamente em função da baixa quantidade de inóculo empregada. Alguns outros fatores podem ter influenciado o processo normal de colonização e reprodução do fungo no inseto. A presença de microrganismos associados externamente ao tegumento e internamente ao trato digestivo das baratas pode interferir de forma negativa nesse processo, causando uma septicemia no início da colonização do inseto pelo fungo. Nessas condições, quando o cadáver apresenta-se em estado de putrefação, especialmente por bactérias, o fungo não encontra condições adequadas para completar seu ciclo.

Outro fator pode estar relacionado à presença do inseticida químico no corpo do inseto, ingerido durante a alimentação das iscas contaminadas nos tratamentos em associação com o fungo. Como observado nos testes da compatibilidade, ambos os inseticidas afetaram o crescimento vegetativo e a reprodução do fungo "in vitro". De acordo com estudos de Pachamuthu et al. (1999) com M. anisopliae e inseticidas usados no controle de baratas, existe uma relação direta entre o crescimento do fungo e a concentração do produto químico, podendo limitar o uso em conjunto desses dois agentes em campo. Em contraste, Zurek et al. (2002) e Pachamuthu \& Kamble (2000) não observaram efeito negativo de alguns inseticidas químicos na infecção e conidiogênese sobre cadáveres de B. germanica infectados por M. anisopliae. O ingrediente ativo e componentes da formulação de um produto químico, além da concentração empregada, podem interferir negativamente no crescimento e reprodução 
de um fungo entomopatogênico (Alves et al., 1998; Alves et al., 2000; Tamai et al., 2002b).

Tabela 8. Efeito do fungo Metarhizium anisopliae e dos inseticidas triflumuron e pyriproxifen sobre colônias de Blattella germanica em laboratório

\begin{tabular}{|c|c|c|c|c|c|c|}
\hline \multirow{4}{*}{$\begin{array}{c}\text { TRATAMENTOS } \\
\text { Testemunha }\end{array}$} & \multicolumn{6}{|c|}{ DIAS APÓS A INSTALAÇÃO DAS COLÔNIAS } \\
\hline & \multicolumn{4}{|c|}{60 dias } & \multirow{2}{*}{\multicolumn{2}{|c|}{$\begin{array}{c}50 \text { dias } \\
\text { Consumo }(\mathrm{mg})^{1}\end{array}$}} \\
\hline & \multicolumn{2}{|c|}{$\mathrm{N}^{0}$ de ninfas } & \multicolumn{2}{|c|}{$\mathrm{N}^{0}$ de adultos ${ }^{1}$} & & \\
\hline & 193,62 & a & 40,24 & $\mathrm{a}$ & 1086,01 & $\mathrm{a}$ \\
\hline $\begin{array}{l}\text { M. anisopliae } \\
\left(0,064 \mathrm{mg} / \mathrm{cm}^{2}\right)\end{array}$ & 158,33 & $a b$ & 27,12 & a & 843,60 & $\mathrm{ab}$ \\
\hline $\begin{array}{c}\text { Pyriproxifen } \\
(1 \%)\end{array}$ & 81,00 & $\mathrm{~b}$ & 0,41 & $\mathrm{~cd}$ & 588,43 & $a b$ \\
\hline $\begin{array}{l}\text { Triflumuron } \\
\qquad(1 \%)\end{array}$ & 56,75 & $\mathrm{~b}$ & 4,05 & $\mathrm{~b}$ & 182,03 & $\mathrm{bc}$ \\
\hline $\begin{array}{l}\text { Pyriproxifen + } \\
\text { M. anisopliae }\end{array}$ & 57,75 & b & 0,00 & $\mathrm{~d}$ & 194,52 & $\mathrm{bc}$ \\
\hline $\begin{array}{l}\text { Triflumuron + } \\
\text { M. anisopliae }\end{array}$ & 38,00 & $\mathrm{~b}$ & 3,76 & bc & 3,37 & $\mathrm{c}$ \\
\hline
\end{tabular}

${ }^{1}$ Dados transformados $\mathrm{y}=\sqrt{\mathrm{x}}$. Medias seguidas por letras distintas diferem entre si ao nível de 5\% de probabilidade

\subsubsection{Avaliação da câmara de infecção Myco-IRC no controle de Blattella germanica em campo}

Após 15 dias da liberação dos insetos, foi possível detectar a movimentação e a atividade alimentar de ninfas e adultos no ambiente. Foram observados insetos próximos à colônia (caixa de papelão) e dentro do recipiente colocado como fonte de alimento, indicando o estabelecimento da população no local. Entretanto, mesmo antes das aplicações dos tratamentos foi observado um grande número de insetos mortos em 
ambos os cômodos. Essa mortalidade está provavelmente relacionada à adaptação da população ao novo ambiente.

Na primeira aplicação, foram consumidas 11,1 e $12,3 \mathrm{mg}$ da isca atrativa nos tratamentos testemunha e MycoIRC, respectivamente, durante as 72 horas de exposição. A população capturada nas armadilhas adesivas após 28 dias da liberação foi de 19 insetos no cômodo que não recebeu tratamento e de apenas 1 inseto no cômodo tratado com a Myco IRC (Tabela 9). Na avaliação do tratamento com a isca contaminada, foram observadas ninfas mortas fora da colônia, que apresentavam-se com o tegumento escurecido ou deformadas.

O consumo da isca atrativa na testemunha durante a segunda aplicação foi cerca 4 vezes maior do que o observado para a primeira aplicação $(44,02 \mathrm{mg})$, reflexo do crescimento da população. Nas avaliações aos 50, 88 e 110 dias foram capturados adultos e ninfas, contudo, apesar da maior atividade alimentar, observou-se um número menor de insetos nas armadilhas. Em contraste, não foi observado consumo da isca contaminada Myco IRC na segunda aplicação e não foram capturados insetos nas armadilhas para as três avaliações (Tabela 9).

Tabela 9. População de Blattella germanica capturada em um período de 72 horas por meio de armadilhas adesivas em colônias de campo (Piracicaba, SP, $13 / 10 / 2003$ a 28/02/2004)

\begin{tabular}{ccccccccc}
\cline { 3 - 8 } DIAS $^{1}$ & \multicolumn{3}{c}{ TESTEMUNHA } & \multicolumn{5}{c}{ MYCO IRC $^{2}$} \\
\hline 28 & fêmea & macho & ninfa & total & fêmea & macho & ninfa & total \\
50 & 2 & 4 & 4 & 10 & 0 & 0 & 0 & 0 \\
88 & 1 & 7 & 2 & 10 & 0 & 0 & 0 & 0 \\
110 & 0 & 3 & 2 & 5 & 0 & 0 & 0 & 0 \\
\hline
\end{tabular}

\footnotetext{
dias após a instalação das colônias

2 aplicações após 15 e 40 dias da instalação das colônias
} 
$\mathrm{Na}$ avaliação das colônias recolhidas ao final do período experimental (140 dias) foi coletado um total de 307 indivíduos vivos no tratamento testemunha, uma população semelhante à liberada inicialmente, contudo, não foram considerados os insetos presentes fora da colônia e no cômodo. A composição populacional foi de 272 ninfas $(88,6 \%), 8$ machos $(2,6 \%)$ e 27 fêmeas $(8,8 \%)$, sendo 8 dessas com ooteca (Figura 15). O elevado número de ninfas pode indicar uma população em crescimento (Cornwell, 1968).

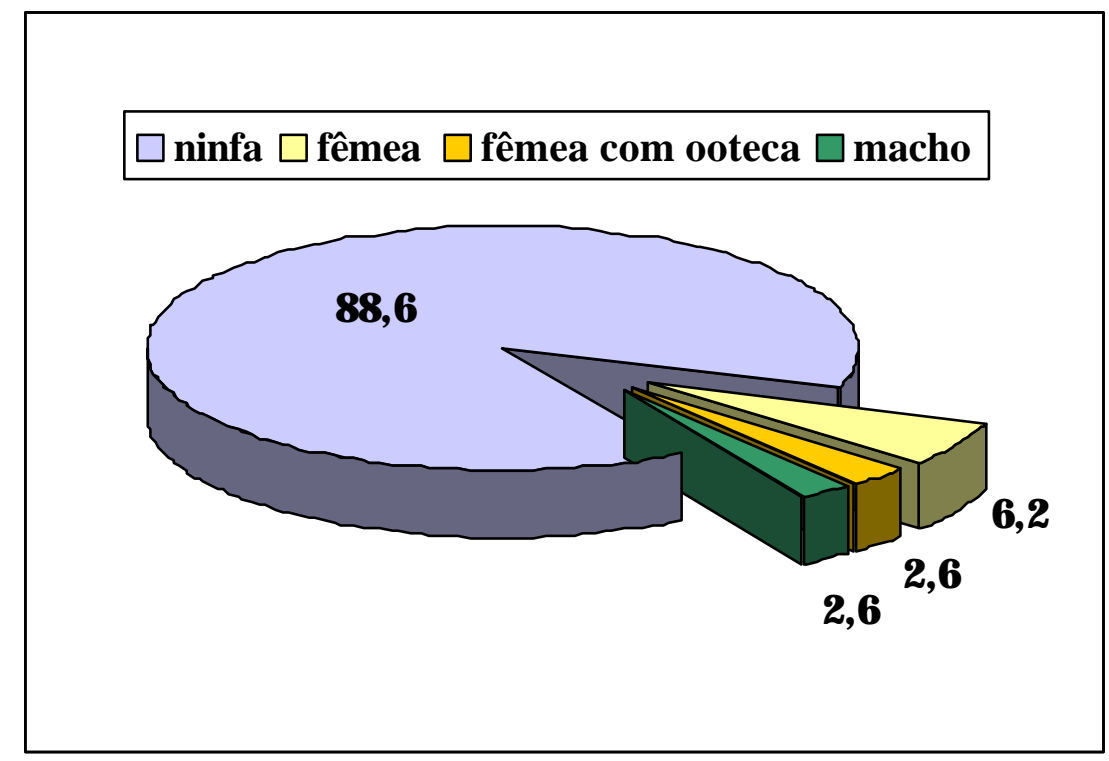

Figura 15 - Composição populacional (\%) da colônia de Blattella germanica no tratamento testemunha após 140 dias (Piracicaba, SP, 28/02/2004)

No tratamento com a isca Myco IRC não foram observados insetos vivos. Também dentro da colônia, foram coletados cadáveres de ninfas enegrecidas em estado de putrefação e ootecas abortadas e deformadas. A exemplo do que ocorreu no teste em colônias em laboratório não foram observados insetos mortos colonizados pelo patógeno. Nesse caso, apesar da maior quantidade de conídios de M. anisopliae empregada na câmara de infecção, o efeito dos dois inseticidas associados à isca provavelmente foi predominante, interferindo na reprodução do patógeno. Contudo, a presença de cadáveres apresentando esporulação do fungo parece não ser o único 
mecanismo de disseminação da doença na colônia. Kaakeh et al. (1996) demostraram que baratas mortas por $M$. anisopliae antes de entrarem em contato com indivíduos sadios foram menos efetivas na disseminação do fungo quando comparadas com baratas vivas e doentes.

São reduzidos os estudos de associação de inseticidas e entomopatógenos que levem em consideração o comportamento de uma população de B. germanica em campo. A maioria dos trabalhos é conduzida em condições de laboratório e com a exposição forçada dos insetos ou em arenas de tamanho limitado (Kaakeh et al., 1996; Pachamuthu \& Kamble, 2000; Zurek et al., 2002). Não são observados fatores relacionados à repelência das formulações, ao tempo de exposição da população ao produto e a presença de outras fontes de alimento presentes no campo. Segundo Kaakeh et al. (1997a), a presença de alimento alternativo em uma colônia retarda a velocidade da morte do insetos em tratamentos que combinam inseticida e M. anisopliae.

Como já discutido anteriormente, a composição da formulação do patógeno, buscando aumentar a quantidade de conídios aderida ao corpo do inseto sem ocasionar a repelência, é importante no desencadeamento do processo de doença. Alguns inertes apresentam maior afinidade eletrostática com o tegumento do inseto, atuando como um carregador de conídios mais efetivo (Oi et al., 1994). A presença de substâncias atrativas na isca contaminada com o inseticida também pode influenciar na performance da câmara de infecção (Kaakeh et al., 1996). Compostos alimentares atrativos ou substâncias semioquímicas, como o feromônio de agregação das baratas presente nas fezes, podem ser avaliados.

Pelos resultados apresentados, comprovou-se a boa eficácia da câmara de infecção Myco IRC, contudo, são necessários testes adicionais em laboratório e campo que levem em consideração vários aspectos não determinados. Entre esses destacam-se a melhor avaliação da contribuição do patógeno na mortalidade da colônia em campo e a concentração máxima dos inseticidas na isca, a fim de não interferir no processo de doença pelo fungo no inseto. 


\subsection{Conclusões}

- Superfícies contaminadas com conídios de $M$. anisopliae $\left(0,064 \mathrm{mg} / \mathrm{cm}^{2}\right)$ não causam repelência aos insetos em colônias de $B$. germanica.

- Os inseticidas triflumuron e pyriproxifen afetam parcialmente o crescimento e a reprodução de $M$. anisopliae em meio de cultura.

- Os inseticidas triflumuron e pyriproxifen aplicados isoladamente e em associação com M. anisopliae reduzem o crescimento de colônias de $B$. germanica em laboratório.

- A associação dos inseticidas com $M$. anisopliae na câmara de infecção Myco-IRC foi efetiva no controle de B. germanica em campo. 


\title{
6 EFEITO DO PARASITISMO DE Gregarina sp. NA SUSCETIBILIDADE DE Blattella germanica (DICTYOPTERA: BLATTELLIDAE) AO FUNGO Metarhizium anisopliae E AO INSETICIDAS TRIFLUMURON
}

\author{
Autor: ROGÉRIO BIAGGIONI LOPES \\ Orientador: Prof Dr. SÉRGIO BATISTA ALVES
}

\section{Resumo}

Os gregarinídeos são parasitos obrigatórios de insetos e, em muitos casos, seus efeitos negativos não são bem conhecidos. Esta pesquisa teve como objetivo determinar a influência do parasitismo por Gregarina sp. na sobrevivência de Blattella germanica expostas ao fungo Metarhizium anisopliae e ao inseticida triflumuron, e avaliar um método de obtenção de colônias de laboratório livres desse protozoário. Adultos foram dissecados e avaliados quanto a freqüência de indivíduos infectados na colônia e as características da colonização pelo microrganismo. Constatou-se a presença de estruturas do protozoário em todo o mesêntero e no proctodéu em $80 \%$ dos indivíduos dissecados. Trofozoítos desenvolvidos e gamontes (solitários e associados) foram observados no mesêntero e cecos gástricos. Oocistos em forma de barril e dispostos em cadeia dentro de esporoductos foram observados em gametocistos recuperados no proctodéu. Os insetos doentes apresentavam movimentação lenta e abdome dilatado, além de antenas curtas, provavelmente causada por mutilação. Os indivíduos mortos apresentavam o corpo escurecido com odor pútrido, indicando septicemia. Insetos infectados com o protozoário expostos ao fungo $M$. anisopliae e ao inseticida triflumuron mostraram-se mais sensíveis ao tratamento em relação a insetos 
sadios. A adoção de técnicas visando ao controle de infecções causadas por gregarinídios é importante para a redução dos efeitos crônicos da doença em sistemas de criação de B. germanica. A obtenção e utilização de insetos sadios em bioensaios de laboratório evita interferências na avaliação de parâmetros biológicos ou fisiológicos da praga, tornando esses estudos, cientificamente, mais precisos. 


\title{
6 EFFECT OF Gregarina sp. PARASITISM ON THE SUSCEPTIBILITY OF Blattella germanica TO SOME CONTROL AGENTS
}

\author{
Author: ROGÉRIO BIAGGIONI LOPES \\ Adviser: Prof Dr. SÉRGIO BATISTA ALVES
}

Summary

Gregarines are ubiquitous and obligate enteric parasites of invertebrates, including insects, but little is known about the negative effects of this parasitism on host species. The present study evaluates the influence of the parasitism of Gregarina sp. on the survival of Blattella germanica and methods for elimination of gregarine infection in laboratory rearing systems. Insects were dissected and the frequency of infected cockroaches in the colony and the characteristics of the gregarine were assessed. The infection was detected in $80 \%$ of a sample of 50 adults. Developed trophozoites and gamonts (solitary and associated) were observed in the midgut and gastric caeca. Barrelshaped oocysts disposed in chains into long sporoducts were observed in gametocysts recovered from the hindgut. Diseased cockroaches had swollen abdomens and slower movement at high incidences of the protozoan, and short antennas, caused probably by mutilation. Dead cockroaches showed darkened body and putrid smell, indicating septicaemia. Infected insects were more susceptible than healthy cockroaches when treated with the entomopathogenic fungus Metarhizium anisopliae and the insect growth regulator triflumuron. The adoption of techniques for control of gregarine infection is important in German cockroach rearing systems, aiming at complete desinfection of the colony or reducing the effects of the disease. The use of healthy cockroaches in laboratory experiments is necessary to avoid negative interferences in the evaluation of biological or physiologic insect parameters. 


\subsection{Introdução}

Os eugregarinídeos (Protista: Apicomplexa) são parasitos intestinais obrigatórios de uma série de invertebrados, que incluem anelídeos, crustáceos, araquinídeos entre outros, sendo a grande maioria das citações referentes a insetos (Clopton, 2002). É o maior grupo do filo Apicomplexa, com cerca de 3124 espécies descritas, um pequeno número quando comparado com o total de espécies de invertebrados conhecidas. Os gregarinídeos são reportados em menos de 0,32\% das espécies de insetos já descritas. A despeito do enorme campo a ser explorado para esse grupo de microrganismos, a morfologia e biologia dos gregarinídeos vem sendo muito estudada nas últimas décadas. Em 1900, apenas 213 espécies de eugregarinídeos eram conhecidas, em 1985 atingiu 1600 espécies e no fim dessa década esse número tinha duplicado (Levine, 1988a; Levine, 1988b).

A patogenicidade desses organismos aos seus hospedeiros ainda permanece em discussão e novas pesquisas devem ser conduzidas para o melhor esclarecimento das relações patógeno-hospedeiro. Para muitos casos não são conhecidos danos significativos causados pela ocorrência de gregarinídeos no trato digestivo dos insetos, exceto em hospedeiros mantidos em condições inadequadas ou de estresse. Entretanto, existem referências na literatura de gregarinídeos, associados ou não a outros microrganismos, causando doença em invertebrados, desde efeitos na reprodução e longevidade de adultos a altos índices de mortalidade (Sneller, 1979; Jackson, 1985; Brooks \& Jackson, 1990; Ball et al., 1995; Johny et al., 2000). Desse modo, deve-se considerar os problemas ocasionados por gregarinídeos em criações de insetos. $\mathrm{O}$ controle dessas infecções torna-se imprescindível em criações massais, seja as destinadas à produção de inimigos naturais como para estudos básicos de biologia, toxicologia e de controle da pragas envolvendo métodos químicos ou biológicos.

No Laboratório de Patologia e Controle Microbiano de Insetos do Setor de Entomologia da ESALQ/USP, Piracicaba (SP), foi observado em uma colônia de Blattella germanica, mantida desde 1998, um aumento incomum na mortalidade de adultos e ninfas. Na dissecação e exame de baratas moribundas foi detectado no trato 
digestivo dos insetos a presença de um grande número de gregarinídeos (gamontes), classificado posteriormente como Gregarina sp. O objetivo do trabalho foi determinar a influência do parasitismo por Gregarina sp. na sobrevivência de B. germanica expostas ao fungo Metarhizium anisopliae e ao inseticida triflumuron, e avaliar um método de obtenção de colônias de laboratório livres desse protozoário.

\subsection{Material e Métodos}

A colônia de B. germanica foi coletada em Piracicaba (SP) e vem sendo mantida em laboratório desde 1998. Os insetos foram criados em recipientes de vidro $(55 \times 25 \times 30 \mathrm{~cm})$ contendo abrigos de papelão corrugado na forma de tubos, dispostos horizontalmente ao fundo do recipiente, em sala escura e temperatura em torno de $27 \pm 2{ }^{\circ} \mathrm{C}$. O fornecimento de água e alimento (ração de cachorro) foi feito duas vezes por semana e os recipientes lavados a cada bimestre (adaptado da metodologia proposta por Singh \& Moore (1985)).

\subsubsection{Características e descrição da infecção}

Insetos moribundos foram dissecados em placas de Petri contendo água destilada, com o auxílio de um estereoscópio (x 6,4). Todo o trato digestivo foi retirado por um corte transversal da porção ventral do abdome do inseto e transferido para uma lâmina de vidro. Foram observadas características da colonização do protozoário e a freqüência de indivíduos parasitados na colônia.

\subsubsection{Controle da doença em criações de laboratório}

Dois grupos de 24 fêmeas com ootecas completamente desenvolvidas e bem escurecidas (fase final do desenvolvimento embrionário) foram selecionados da criação infectada com o protozoário. As baratas foram anestesiadas com $\mathrm{CO}_{2} \mathrm{e}$ as ootecas retiradas com o auxílio de um pinça pressionando-se com cuidado os últimos tergitos 
abdominais. As 48 fêmeas foram dissecadas e avaliadas quanto a presença do protozoário no trato digestivo e a quantidade de estruturas do microrganismo por indivíduo (ausência = 0 gamontes; baixa = 1-30 gamontes; alta $=$ acima de 30 gamontes). Cada grupo de 24 ootecas foi dividido em seis repetições que foram transferidas para copos plásticos contendo um bebedouro de água e ração de cachorro. Um dos grupos recebeu $1 \mathrm{~g}$ de fezes coletados dos recipientes de criação com presença de oocistos. Os copos permaneceram em câmara climatizada (24 horas de escotofase; $27 \pm 2^{\circ} \mathrm{C}$ ) até o desenvolvimento das ninfas recém eclodidas em adultos.

Foram avaliados o número de ootecas viáveis, o número de ninfas eclodidas por ooteca e a incidência da doença na fase adulta (presença de gamontes no trato digestivo) para os dois grupos. O método proposto consiste na obtenção de insetos livres da doença e a criação de uma nova colônia, partindo do princípio que com esse procedimento não existe a transmissão vertical do protozoário.

\subsubsection{Influência do parasitismo na sobrevivência de adultos e ninfas}

Foi determinada a influência da infecção por Gregarina sp. na mortalidade de B. germanica inoculadas com o fungo $M$. anisopliae e alimentadas com o inseticida regulador de crescimento triflumuron (Alsystin 250PM) em condições de laboratório. Os indivíduos sadios dos experimentos com o fungo e com o inseticida foram obtidos seguindo-se o método descrito no item 3.2.3, por meio da separação ootecas e criação dos insetos até a idade desejada (adultos recém emergidos e ninfas de entre 35 e 40 dias de idade). Os insetos doentes foram coletados diretamente da colônia.

No teste com M. anisopliae, dois grupos de 48 adultos doentes e mais dois

grupos de 48 adultos sadios, totalizando quatro tratamentos, foram inicialmente separados. Cada tratamento foi dividido em quatro repetições de 12 insetos e transferidos para copos plásticos contendo alimento e água. Um grupo de insetos doentes e outro de insetos sadios foram adormecidos com $\mathrm{CO}_{2}$ e receberam, individualmente, na porção external $1 \mu \mathrm{L}$ de uma suspensão $5 \times 10^{8}$ conídios $/ \mathrm{mL}$ do fungo por meio de 
aplicação tópica (Microaplicador Burkard Manufacturing CoLtd.). As testemunhas sadias e doentes receberam apenas água destilada.

Para o inseticida triflumuron os tratamentos foram divididos da mesma maneira como descrito no teste anterior, contudo foram utilizadas ninfas de 30 a 35 dias de idade. Nesse caso, a aplicação foi feita por meio da contaminação do alimento, misturando-se o inseticida à ração de cachorro triturada na concentração de $1 \%$ de ingrediente ativo na isca. Em cada copo foi colocado $0,5 \mathrm{~g}$ da ração tratada e os grupos sadio e doente da testemunha receberam apenas ração. Alimento sem inseticida foi fornecido para todos os tratamentos quando necessário até o término do teste.

Os insetos foram mantidos em condições controladas (24 horas de escotofase; $27 \pm 2^{\circ} \mathrm{C}$ ) durante todo o experimento e as avaliações de mortalidade foram realizadas diariamente até o vigésimo dia. Os dados foram submetidos à análise de Probit e determinou-se o tempo letal $\left(\mathrm{TL}_{25}\right)$ para os grupos doentes e sadios.

\subsection{Resultados e Discussão}

Na avaliação inicial de uma amostra de cinqüenta insetos adultos da colônia foi constatada a infecção em $80 \%$ dos indivíduos, evidenciando o potencial de transmissão horizontal de Gregarina sp. em condições de criação em laboratório (Brooks \& Jackson, 1990). O protozoário foi também observado em grandes quantidades nos últimos ínstares ninfais. Os gregarinídeos são considerados parasitas altamente específicos, geralmente restritos a um único hospedeiro. A idéia empírica de que "hospedeiros distintos indicam parasitas distintos" é amplamente discutida na literatura. Clopton \& Gold (1996) não observaram o estabelecimento de infecção por Gregarina blattarum obtido de B. germanica em outras quatro espécies de baratas. Provavelmente, essa espécie de protozoário representa um grande complexo de espécies. Estudos mais detalhados são necessários para a identificação da espécie do gregarinídeo descrita no presente trabalho.

$\mathrm{Na}$ maioria dos insetos dissecados foram encontrados trofozoítos desenvolvidos, mostrando o epemerito globular (Figura 16A), e gamontes (solitários e 
associados) em todo o mesêntero, inclusive nos cecos gástricos. Em baratas com alta infestação do protozoário, centenas de gamontes ocupavam completamente o mesêntero, tornando-o dilatado e, provavelmente, dificultando o fluxo do alimento (Figura 16B). Gametocistos esféricos foram observados ainda na porção final do mesêntero, mas principalmente envolto pela massa alimentar na região do proctodéu (Figura 16D). Os gametocistos recuperados do trato digestivo dos insetos e transferidos para placas com papel de filtro umedecido produziram esporodutos longos, contendo oocistos em forma de barril e dispostos em cadeia (Figura 16C). Foram observados também oocistos nas fezes de insetos infectados.
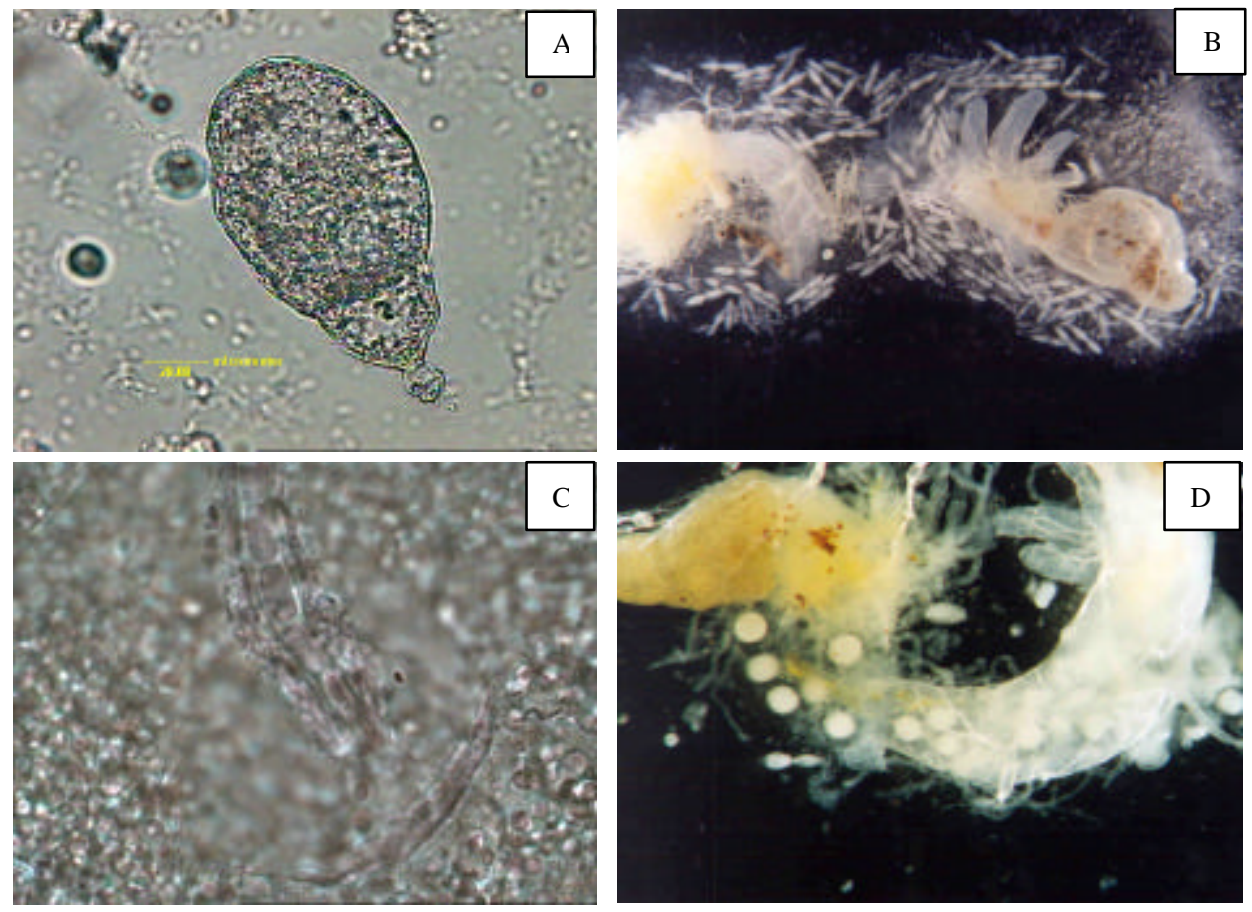

Figura 16 - A) trofozoítos desenvolvidos - epemerito (Ep), protomerito (Pro), deutomerito (Deu); B) gamontes (G) no trato digestivo; C) esporoducto contendo oocistos (Oc); D) gametocistos (Gam)

A grande proporção de ninfas mortas, incomum em condições normais de criação, chamou a atenção quanto a ocorrência de uma doença na população e, provavelmente, esteja ligada a presença do protozoário. Observações da hemolinfa, 
tecido gorduroso e trato digestivo não indicaram a ocorrência de outro agente infectivo. Os indivíduos mortos apresentavam o corpo escurecido e com odor pútrido, indicando septicemia. Os insetos também apresentavam movimentação lenta e abdome dilatado, causado pelo aumento do trato digestivo em condições de alta incidência do protozoário. Sintomas semelhantes foram observados por Ball et al. (1995) em criações de laboratório de Gromphadorhina portentosa. Os autores constataram a ocorrência de um gregarinídeo no trato digestivo dos insetos e sugeriram que a doença e o alto índice de mortalidade na colônia, provavelmente, estejam relacionados também com a presença do protozoário.

O impedimento do fluxo normal do alimento pelo trato digestivo pode também interferir de forma negativa na nutrição do inseto. Os insetos doentes apresentavam ainda as antenas curtas e curvadas. A redução do número de antenômeros está provavelmente ligada à insuficiência nutricional causada pela doença, mas pode estar relacionada também à mutilação dos insetos doentes. A agressividade e o canibalismo entre indivíduos em superpopulações é freqüente em baratas (Ross \& Mullins, 1995) e acaba sendo mais intensa sobre insetos doentes e lentos. Sintomas muito semelhantes também foram descritos por Archbold et al. (1986) em colônias de laboratório de B. germanica infectadas com leveduras. Tais sintomas indicam a provável ocorrência de mais de um microrganismo agindo sobre a população, contudo, nesse caso não foi detectada sua presença. Estudos adicionais são necessários para e determinação mais precisa do agente causal da doença.

Estruturas do protozoário foram também encontradas em insetos aparentemente sadios mesmo após os picos de mortalidade, porém em número reduzido, determinando a predominância do comportamento crônico da doença. A ocorrência de infecções crônicas de gregarinídeos em baratas é amplamente relatada na literatura, tanto em colônias mantidas em laboratório (Clopton, 1995; Clopton \& Gold, 1996) como em insetos capturados no campo (Serra-Freire, 1999). A condição aguda da doença, refletindo em alta mortalidade, foi provavelmente ocasionada por fatores de estresse não determinados em que a criação ficou temporariamente submetida. Vários fatores podem ser relacionados, como mudanças bruscas de temperatura, a falta ou inadequação do 
alimento, a superpopulação em regime contínuo de criação ou o excesso de fezes e indivíduos mortos no recipiente. Essas condições levaram a um aumento do inóculo do patógeno conduzindo à novas e freqüentes reinfestações e ao aumento do número de insetos doentes.

Das 48 fêmeas de B. germanica utilizadas para a retirada das ootecas, 83,3\% apresentaram estruturas do protozoário, sendo 43,7\% com alta e 39,6\% com baixa incidência, resultado semelhante à avaliação inicial da colônia. A viabilidade das ootecas foi de $66,7 \%$ e a produção média foi de 30,9 ninfas por ooteca viável, revelando que apesar de trabalhoso, o método apresenta um bom rendimento. A separação de ootecas e a criação dessa nova geração em recipientes desinfectados, sem o contato com fezes ou indivíduos doentes, possibilita a formação de novas colônias completamente sadias. Cem por cento $(100 \%)$ dos indivíduos que não tiveram contato com fezes contaminadas não apresentaram infecção por Gregarina sp. na fase adulta. Do grupo que recebeu fezes já na eclosão das ninfas, $23 \%$ das baratas na fase adulta apresentaram infecção, sendo baixa (1-30 gamontes) em 21\% e alta (acima de 30 gamontes) em apenas $2 \%$ dos indivíduos avaliados. A baixa taxa de infecção observada no grupo deveu-se, provavelmente, pela quantidade limitada de inóculo (oocistos) contido em 1 grama de fezes, além dos insetos não estarem submetidos à condições de estresse como a falta de alimento ou superpopulação. A razão sexual foi semelhante, de 1:1 e 1,38:1 para os grupos sadio e infectado, respectivamente.

Os insetos sadios obtidos com esse método apresentaram desenvolvimento normal até a fase adulta. Aparentemente, a não aquisição de outros microrganismos, que podem auxiliar no processo digestivo dos insetos, pelo hábito de coprofagia de ninfas recém-eclodidas não interferiu negativamente na população.

Alguns outros métodos de controle da doença causada por Gregarina sp. em criações de B. germanica podem ser adotados visando minimizar os efeitos da infecção. Evitar altas populações e a limpeza periódica dos recipientes de criação são procedimentos simples que reduzem a infestação pelo protozoário. Clopton \& Smith (2002) propuseram o tratamento da colônia com produtos antimicrobianos via oral, o que reduziu a infecção por gregarinídeos em criações da barata Blaberus discoidalis. 
Modificações no sistema de criação podem também proporcionar um bom controle da doença. Recipientes cilíndricos presos à parede, permitindo que os abrigos permaneçam na vertical sobre uma peneira e evitando o acúmulo de sujeira, limitam o contato frequiente dos insetos com os oocistos contidos nas fezes. Nesse sistema, também usado no Setor de Entomologia da ESALQ/USP, a freqüência de insetos com estruturas do protozoário no trato digestivo foi de $62,5 \%$, com alta infestação em apenas $22,5 \%$ dos insetos.

Nos testes com M. anisopliae e triflumuron não observou-se mortalidade para os grupos de insetos não infectados pelo protozoário que não receberam tratamento algum (testemunhas sadias). Os insetos que também não foram tratados, mas que foram coletados na colônia infectada com o protozoário (testemunhas doentes), apresentaram mortalidade apenas entre 10 e $20 \%$, reforçando a característica crônica da doença. Tanto para o inseticida como para o fungo, a mortalidade de insetos após 20 dias nos grupos sadios foi menor do que a observada para os insetos infectados (Figuras. 17 e 18).

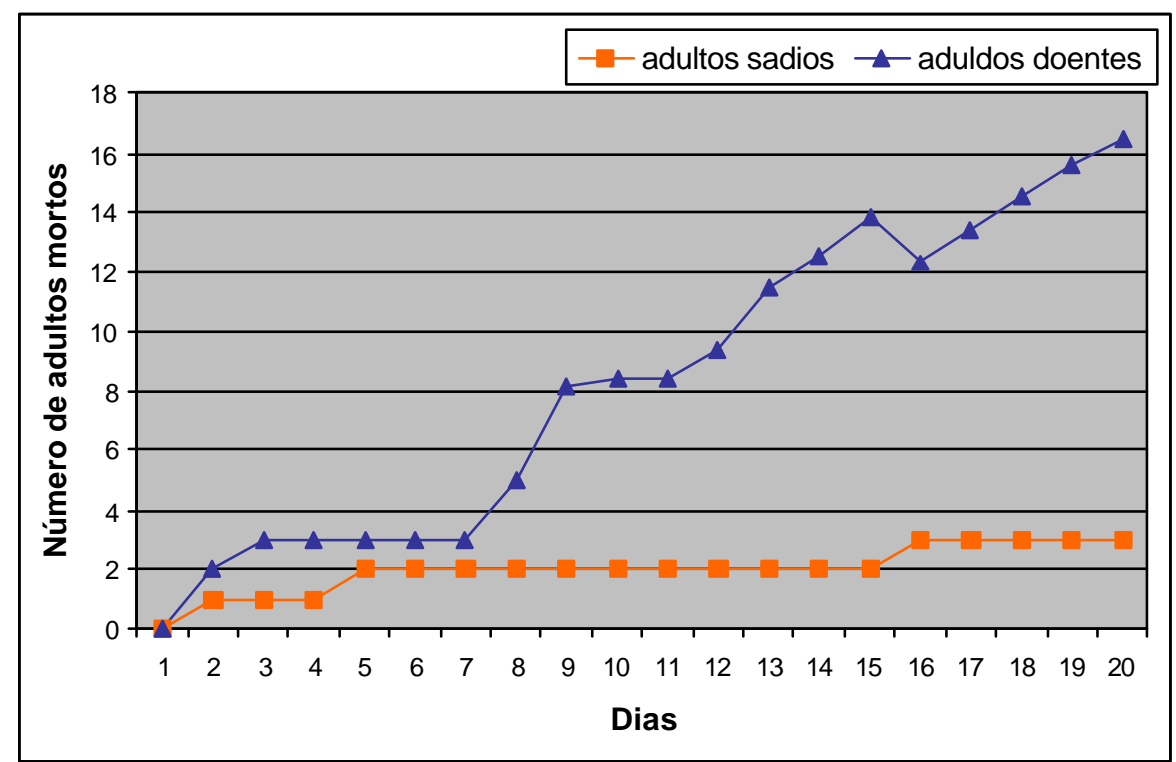

Figura 17 - Mortalidade de adultos de Blattella germanica infectados e não infectados por Gregarina sp. submetidos ao tratamento com o fungo Metarhizium anisopliae $\left(5 \times 10^{5}\right.$ conídios/inseto $)$ 


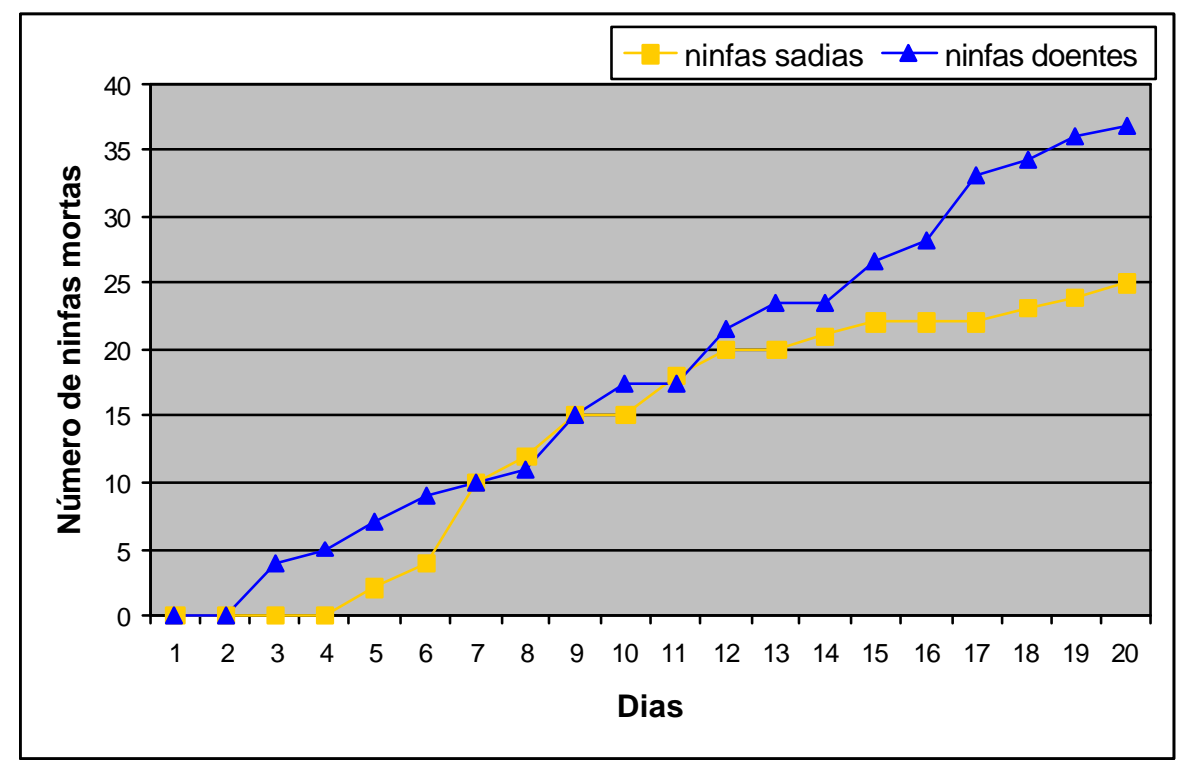

Figura 18 - Mortalidade de ninfas de Blattella germanica infectadas e não infectadas por Gregarina sp. alimentadas com o inseticida triflumuron (1\% i.a. no alimento)

Para M. anisopliae, o $\mathrm{TL}_{25}$ dos insetos infectados foi de 15,26 dias, com limites entre 13,15 e 18,58 dias, e para os não infectados a mortalidade ao final do experimento foi inferior a 10\%, impossibilitando a determinação do tempo letal (Tabela 10).

Tabela 10. Valores de tempo letal $\left(\mathrm{TL}_{25}\right)$ de adultos de Blattella germanica infectados e não infectados por Gregarina sp. submetidos ao tratamento com o fungo Metarhizium anisopliae $\left(5 \times 10^{5}\right.$ conídios/inseto)

\begin{tabular}{cccccc}
\hline TRATAMENTOS & $\mathrm{n}$ & SLOPE + SE & $\mathrm{TL}_{25}$ & I.C. $(95 \%)^{\mathrm{a}}$ & $\chi^{2}$ \\
\hline não infectado & 48 & - & - & - & ${ }^{\mathrm{b}}$ \\
infectado & 48 & $1,592 \pm 0,214$ & 15,261 & $13,150-18,537$ & 5,505 n.s.
\end{tabular}

\footnotetext{
${ }^{a}$ significativo quando não houver sobreposição do intervalo de confiança (I.C.)

${ }^{\mathrm{b}}$ os dados não seguem o modelo Probit
} 
Nesse caso, a comparação entre os tratamentos pelo tempo letal seria, provavelmente, possível em doses mais elevadas ou avaliando-se a mortalidade dos insetos por um período mais longo. Para o tratamento com o inseticida triflumuron foi possível observar o efeito negativo do protozoário sobre as ninfas infectadas. $\mathrm{O}_{\mathrm{TL}} 25$ para ninfas infectadas foi de 7,425 dias, com limites entre 6,68 e 8,10 dias. Já para insetos sadios esse valor foi de 9,422 dias, com limites entre 8,55 e 10,23 dias (Tabela 11). Provavelmente, o protozoário não foi responsável pela morte, mas tornou os insetos mais sensíveis ao tratamento, seja ele pelo fungo ou pelo inseticida, levando a uma interpretação superestimada da eficiência desses produtos.

Tabela 11. Valores de tempo letal $\left(\mathrm{TL}_{25}\right)$ de ninfas de Blattella germanica infectadas e não infectadas por Gregarina sp. alimentadas com o inseticida triflumuron (1\% i.a. no alimento)

\begin{tabular}{cccccc}
\hline TRATAMENTOS & $\mathrm{n}$ & SLOPE $+S E$ & TL $_{25}$ & I.C. $(95 \%)^{\mathrm{a}}$ & $\chi^{2}$ \\
\hline não infectado & 48 & $2,726 \pm 0,245$ & 9,422 & $8,549-10,232$ & 14,161 n.s. \\
infectado & 48 & $2,808 \pm 0,215$ & 7,425 & $6,681-8,102$ & 9,953 n.s.
\end{tabular}

${ }^{a}$ significativo quando não houver sobreposição do intervalo de confiança (I.C.)

O método proposto no presente trabalho baseia-se no simples conceito de quebra do mecanismo de transmissão vertical do protozoário, levando a desinfecção completa da colônia. A importância de uma colônia livre do protozoário reside no fato de que infecções crônicas, que não induzam a expressão de sintomas claros nos indivíduos, podem interferir na avaliação de parâmetros biológicos ou fisiológicos do inseto, e atuam como um fator de erro nos estudos. Insetos infectados com o protozoário podem responder de maneira diferente em comparação a insetos sadios quando, por exemplo, submetidos a um agente biológico, como observado para o fungo $M$. anisopliae e para o pesticida químico triflumuron, superestimando ou subestimando o efeito dos produtos. 


\subsection{Conclusões}

- O protozoário Gregarina sp. ocasiona altos índices de mortalidade e declínio de colônias de laboratório de $B$. germanica submetidas à condições inadequadas de criação ou de estresse.

- Insetos infectados com Gregarina sp. apresentaram-se mais sensíveis a ação do inseticida triflumuron e do fungo $M$. anisopliae quando comparados com insetos sadios.

- O método de separação de ootecas de fêmeas infectadas por Gregarina sp. e a criação da nova geração isolada dos insetos doentes promove a desinfeção completa da colônia, visando a utilização de insetos sadios em experimentos científicos. 


\section{CONCLUSÕES GERAIS}

- O fungo $M$. anisopliae (ESALQ-1037) é patogênico para ninfas e adultos de $B$. germanica.

- Ninfas de B. germanica são menos sensíveis à infecção pelo patógeno do que aldultos.

- Iscas atrativas formuladas com conídios de $M$. anisopliae não causam mortalidade de B. germanica via oral.

- A formulação de M. anisopliae em talco aplicada na superfície de caminhamento dos insetos causa altos índices de mortalidade de adultos e ninfas de B. germanica.

- Iscas atrativas formuladas com triflumuron nas concentrações de 0,5 e $1 \%$ de ingrediente ativo, em um período de exposição de 72 horas, causam índices satisfatórios de mortalidede de ninfas de B. germanica.

- Iscas atrativas formuladas com os inseticidas triflumuron (1\%) e pyriproxifen (1\%) provocam efeitos negativos na reprodução de B. germanica.

- Fêmeas virgens expostas à isca atrativa com pyriproxifen (1\%) por um período de 72 horas não produzem descendentes.

- Superfícies contaminadas com conídios de $M$. anisopliae $\left(0,064 \mathrm{mg} / \mathrm{cm}^{2}\right)$ não causam repelência aos insetos em colônias de B. germanica.

- Os inseticidas triflumuron e pyriproxifen afetam parcialmente o crescimento e a reprodução de $M$. anisopliae em meio de cultura.

- Os inseticidas triflumuron e pyriproxifen aplicados isoladamente e em associação com M. anisopliae reduzem o crescimento de colônias de B. germanica em laboratório. 
- A associação dos inseticidas com M. anisopliae na câmara de infecção Myco-IRC foi efetiva no controle de B. germanica em campo.

- O protozoário Gregarina sp. ocasiona altos índices de mortalidade e declínio de colônias de laboratório de $B$. germanica submetidas à condições inadequadas de criação ou de estresse.

- Insetos infectados com Gregarina sp. apresentaram-se mais sensíveis a ação do inseticida triflumuron e do fungo $M$. anisopliae quando comparados com insetos sadios.

- O método de separação de ootecas de fêmeas infectadas por Gregarina sp. e a criação da nova geração isolada dos insetos doentes promove a desinfeção completa da colônia, visando a utilização de insetos sadios em experimentos científicos. 


\section{REFERÊNCIAS BIBLIOGRÁFICAS}

ADAMSON, M.L.; NOBLE, S. Structure of the pinworm (Oxyurida: Nematoda) guild in the hindgut of the Amercan cockroach Periplaneta americana. Parasitology, v.104, p.497-507, 1992.

ADAMSON, M.L.; VAN WAEREBEKE, D. Revision of the Thelastomatoidea, Oxyurida of invertebrate host 2. Travassosinematidae, Protrelloididae and Pseudonymidae. Systematic Parasitology, v.21, p.169-188, 1992.

AGUILERA, L.; MARQUETTI, M.C.; NAVARRO, A. Actividad biológica del diflubenzuron sobre Blattella germanica (Dictyoptera: Blattellidae). Revista Cubana de Medicina Tropical, v.53, n.1, p.48-52, 2001.

ALVES, S.B. Fungos entomopatogênicos. In: ALVES, S.B. (Ed.). Controle microbiano de insetos. Piracicaba: Fealq, 1998. cap.11, p.289-381.

ALVES, S.B.; LECUONA, R.E. Epizootiologia aplicada ao controle microbiano de insetos. In: ALVES, S.B. (Ed.). Controle microbiano de insetos. Piracicaba: Fealq, 1998. cap.5, p.97-169.

ALVES, S.B.; LOPES, R.B.; TAMAI, M.A.; MOINO JR., A.; ALVES, L.F.A. Compatibilidade de produtos fitossanitários com entomopatógenos em citros. Laranja, v.21, n.2, p.295-306, 2000. 
ALVES, S.B.; MOINO JR., A.; ALMEIDA, J.E.M. Produtos fitossanitários e entomopatógenos. In: ALVES, S.B. (Ed.). Controle microbiano de insetos. Piracicaba: Fealq, 1998. cap. 8, p. 217-238.

ALVES, S.B.; PEREIRA, R.M.; LOPES, R.B.; TAMAI, M.A. Use of entomopathogenic fungi in Latin America. In: UPADHYAY, R.K. (Ed.) Advances in microbial control of insect pests. New York: Kluwer Academic/Plenum Publishers, 2002b. p.193-211.

ALVES, S.B.; ALVES, L.F.A.; LOPES, R.B.; PEREIRA, R.M.; VIEIRA, S.A. Potential of some Metarhizium anisopliae isolates for control of Culex quinquefasciatus (Dip., Culicidae). Journal of Applied Entomology, v.126, p.504-509, 2002a.

APPEL, A.G. Blattella and related species. In: RUST, M.K.; OWENS, J.M.; REIERSON, D.A. (Ed.) Understanding and controlling the German cockroach. New York: Oxford University Press, 1995. cap.1, p.1-19.

APPEL, A.G.; BENSON, E.P. Pathogenicity and limited transoothecal transmission of Steinernema carpocapse (Nematoda: Steinernematidae) in adult female German cockroaches (Dictyoptera: Blattellidae). Journal of Medical Entomology, v.31, n.1, p.127-131, 1994.

APPEL, A. G.; BENSON, E.P.; ELLENBERGER, J.M.; MANWEILER, S.A. Laboratory and field evaluations of an entomogenous nematode (Nematoda: Steinernematidae) for German cockroach (Dictyoptera: Blattellidae) control. Journal of Economic Entomology, v.86, n.3, p.777-784, 1993.

ARCHBOLD, E.F.; RUST, M.K.; REIERSON, D.A.; ATKINSON, K.D. Characterization of a yeast infection in the German cockroach (Dictyoptera: Blattellidae). Environmental Entomology, v.15, p.221-226, 1986. 
ARISMENDY, E.L.; PERALTA, S.O. Metarhizium anisopliae y Trichoderma viride controlan colonias de Atta cephalotes en campo mejor que un inseticida químico. Revista Colombiana de Biotecnologia, v.4, n.1, p.71-78, 2002.

BALL, S.J.; CUNNINGHAM, A.A.; CLARKE, D.; DASZAK, P. Septate gregarines associates with a disease of the hissing cockroach Gromphadorhina portentosa. Journal of Invertebrate Pathology, v.65, p.311-312, 1995.

BENNETT, G.W.; REID, B.L. Insect growth regulators. In: RUST, M.K.; OWENS, J.M.; REIERSON, D.A. (Ed.). Understanding and controlling the German cockroach New York: Oxford University Press, 1995. cap.11, p.267-286.

BENNETT, G.W.; YONKER, J.E.; RUNSTROM, E.S. Influence of hydroprene on German cockroaches (Dictyoptera: Blattellidae) populations in public housing. Journal of Economic Entomology, v.79, n. 4, p.1032-1035, 1986.

BORGES, M.S.; HULETT, A.C.; FONSECA, F.C.; CALDAS, E.F. Mite and cockroach sensitization in allergic patients from Caracas, Venezuela. Annals of Allergy, Atshma and Immunology, v.90, n.6, p.664-668, 2003.

BOUCIAS, D.G.; PANDLAND, J.C. Principles of insect pathology. Boston: Kluwer Academic Publishers, 1998. 537p.

BOUCIAS, D.G.; STOKES, C.; STOREY, G.; PENDLAND, J.C. The effects of imidacloprid on the termite Reticulitermes flavipes and its interaction with the mycopathogen Beauveria bassiana. Pflanzenschutz Nachrichten Bayer, v. 49, n.2, p.103-144, 1996. 
BRENNER, R.J. Economics and medical importance of German cockroaches. In: RUST, M.K.; OWENS, J.M.; REIERSON, D.A. (Ed.). Understanding and controlling the German cockroach New York: Oxford University Press, 1995. cap.4, p.77-92.

BRENNER, R.J.; KOEHLER, P.G.; PATTERSON, R.S. Integration of fenoxycarb into a German cockroaches (Orthoptera: Blattellidae) management program. Journal of Economic Entomology, v.81, n.5, p.1404-1407, 1988.

BROOKS, W.M.; JACKSON, J. Eugregarines: current status as pathogens, illustrated in corn rootworms. IN: INTERNATIONAL COLLOQUIUM ON INVERTEBRATE PATHOLOGY AND MICROBIAL CONTROL, 5., Adelaide, Au, 1990. Proceedings. Adelaide, Au: Society of Invertebrate Pathology, 1990. p.512-515.

BUCZKOWSKI, G.; SCHAL, C. Method of insecticide delivery affects horizontal transfer of fipronil in the german cockroach (Dictyoptera: Blattellidae). Journal of Economic Entomology, v.94, n.3, p.680-685, 2001.

CARRER, P.; MARONI, M.; ALCINI, D.; CAVALLO, D. Allergens in indoor air: environmental assessment and health effects. The Science of the Total Environmental, v.270, p.33-42, 2001.

CHANDRASHEKHAR, S.; SURYANARAYANAN, T.S.; MURTHY, V.A. Effects of citrinin, a mycotoxin, on behaviour of cockroach. Current Science, v.59, n.2, p.108-109, 1990.

CLARK, J.W.; KAMBHAMPATI, S. Phylogenetic analyses of Blattabacterium, endosymbiotic bacteria from the wood roach, Cryptocercus (Blattodea: Cryptocercidae), including a description of three new species. Molecular Phylogenetics and Evolution, v.26, p.82-88, 2003. 
CLOPTON, R.E. Leidyana migrator n. sp. (Apicomplexa: Eugregarinida: Leidyanidae) from the Madagascar hissing cockroach, Gramphadorhina portentosa (Insecta: Blattodea). Invertebrate Biology, v.114, n.4, p.271-278, 1995.

CLOPTON, R.E. Phylum Apicomplexa Levine, 1970: Order Eugregarinorida. In: LEE, J.J.; LEEDALE, G.; PATTERSON, D.; BRADYBURY, P.C. Illustrated Guide to the Protozoa. 2.ed. Lawrence, Kansas: Society of Protozoologists, 2002. p.205-288.

CLOPTON, R.E.; GOLD, R.E. Host specificity of Gregarina blattarum von Siebold, 1839 (Apicomplexa: Eugregarinida) among five species of domiciliary cockroaches. Journal of Invertebrate Pathology, v. 67, p.219-223, 1996.

CLOPTON, R.E. SMITH, A. Efficacy of oral sulfadimethoxine against two gregarine parasites, Protomagalhaensia granulosae and Gregarina cubensis (Apicomplexa: Eugregarinida), infecting the death's head cockroach, Blaberus discoidalis. Journal of Parasitology, v.88, n.4, p.786-789, 2002.

COCHRAN, D.G. Insecticide resistance. In: RUST, M.K.; OWENS, J.M.; REIERSON, D.A. (Ed.). Understanding and controlling the German cockroach New York: Oxford University Press, 1995. cap.8, p.171-192.

COCHRAN, D.G. Cockroaches: their biology, distribution and control. Genebra: World Health Organization (WHO/CDS/CPC/WHOPES/99.3), 1999. 83p.

CORNWELL, P.B. The cockroach: a laboratory insect and an industrial pest. London: The Rentokil Library, 1968. v.1. 391p.

CORNWELL, P.B. The cockroach: insectcides and cockroach control. London: The Rentokil Library, 1976. v.2. 557p. 
DAS, Y.T.; GUPTA, A.P. Abnormalities in the development and reproduction of Blattella germanica (L.) (Dictyoptera: Blattellidae) treated with insect growth regulators with juvenile hormone activity. Experientia (Basel), v.33, p.968-970, 1977.

DEMARK, J.J.; BENNETT, G.W. Efficacy of chitin synthesis inhibitors on nymphal German cockroaches (Dictyoptera: Blattellidae). Journal of Economic Entomology, v.82, n.6, p.1633-1637, 1989.

DHADIALLA, T.S.; CARLSON, G.R.; LE, D.P. New insecticides with ecdysteroidal and juvenile hormone activity. Annual Review of Entomology, v.43, p.545-569, 1998.

DIEHL-FLEIG, E.; LUCCHESE, M.E. Reações comportamentais de operárias de Acromyrmex striatus (Hymenoptera: Formicidae) na presença de fungos entomopatogênicos. Revista Brasileira de Entomologia, v.35, n.1, p.101-107, 1991.

DURIER, V.; RIVAULT,C. Secondary transmission of toxic baits in German cockroach (Dictyoptera: Blattellidae). Journal of Economic Entomology, v.93, n.2, p.434440, 2000.

EBELING, W. Pests On or Near Food. In: EBELING, W. (Ed.) Urban Entomology. Riverside: Entomology UC Riverside, 2002. cap.6, p. 217-274.

EVANS, H.; SHAPIRO, M. Viruses. In: LACEY, L.A. (Ed.) Manual of techniques in insect pathology. London: Academic Press, 1997. p.17-53. 
GAHLHOFF Junior, J.E.; MILLER, D.M.; KOEHLER, P.G. Secondary kill of adult male german cockroaches (Dictyoptera: Blattellidae) via cannibalism of nymphs fed toxic baits. Journal of Economic Entomology, v.92, n.5, p.1133-1137, 1999.

GEORGHIOU, G.P.; LAGUNES-TEJEDA, A. The occurrence of resistance to pesticides in arthropods. Rome: Food Agricultural Organization, 1991.318p.

GEORGIS, R.; KAYA, H.K. Formulation of entomopathogenic nematodes. In: BURGES, H.D. (Ed.) Formulation of microbial biopestcides. London: Kluwer Academic Publishers, 1998, cap.9, p.289-308.

GLARE, T.R.; O'CALLAGHAN, M. Bacillus thuringiensis: biology, ecology and safety. Chichester: John Wiley, 2000. 350p.

GOLD, R.E. Alternative control strategies. In: RUST, M.K.; OWENS, J.M.; REIERSON, D.A. (Ed.). Understanding and controlling the German cockroach New York: Oxford University Press, 1995. cap.13, p.325-343.

GRANDCOLAS, P.; DELAPORTE, P. The origin of protistan symbionts in termites and cockroaches: a phylogenetic perspective. Cladistics, v.12, p.93-98, 1996.

GUNNARSSON, S.G.S.; LACKIE, A.M. Hemocytic aggregation in Schistocerca gregaria and Periplaneta americana in response to injected substances of microbial origin. Journal of Invertebrate Pathology, v. 46, p.312-319, 1985.

GUPTA, S.C.; LEATHERS, T.D.; EL-SAYED, G.N.; IGNOFFO, C.M. Production of degradative enzymes of Metarhizium anisopliae during growth on defined media and insect cuticle. Experimental Mycology, v.15, p.310-315, 1991. 
HAHNSTADT, R.L. Alergia às baratas: um novo vilão entra em cena. Vetores\&Pragas, v.2, n.4, p.36-39, 1999.

HUNT, D. Acugutturus parasiticus, n.g., n.sp., a remarkable ectoparasitic aphelencoid nematode from Periplaneta americana (L.), with proposal Acugutturinae, n. subf. Systematic Parasitology, v.1, p.167-170, 1980.

HUSS, K.; ADKINSON Junior., N.F.; EGGLESTON, P.A.; DAWSON, C.; VAN NATTA, M.L.; HAMILTON, R.G. House dust mite and cockroach exposure are strong risk factors for positive allergy skin test response in the childhood asthma management program. Journal of Allergy and Clinical Immunology, v.107, n.1, p.48-54, 2001.

HUXHAM, I.M.; LACKIE, A.M.; MCCORKINDALE, N.J. Inhibitory effects of cyclodepsipeptides, destruxins, from the fungus Metarhizium anisopliae, on cellular immunity in insects. Journal of Insect Physiology, v.35, n.2, p.97-105, 1989a.

HUXHAM, I.M.; SAMUELS, K.D.Z.; HEALE, J.B.; MCCORKINDALE, N.J. In vivo and in vitro assays for pathogenicity of wild-type and mutant strains of Metarhizium anisopliae for three insect species. Journal of Invertebrate Pathology, v.53, p.143-151, 1989b.

IMMS, A.D. Recent advances in entomology. Philadelphia: P. Blakinston's Son, 1931. $374 \mathrm{p}$.

ISHII, S.; KUWAHARA, Y. An aggregation pheromone of the German cockroach Blattella germanica (Orthoptera: Blattellidae). 1. Site of the pheromone production. Applied Entomology and Zoology, v.2, p.203-217, 1967. 
JACCOUD, D.B.; HUGES, W.H.O.; JACKSON, C.W. Epizootiology of a Metarhizium infection in mini-nests of the leaf-cutting ant Atta sexdens rubropilosa. Entomologia Experimentalis et Applicata, v.93, p.51-61, 1999.

JACKSON, J. Diabrotica spp. IN: SINGH, I.P.; MOORE, R.F. (Ed.). Handbook of insect rearing, Amsterdam, Netherlands: Eslsevier. 1985. v.1, p.237-251.

JOHNY, S.; MURALIRANGAN, M.C.; SANJAYAN, K.P. Parasitization potential of two cephaline gregarines, Leidyana subramanii Pushkala and Muralirangan and Retractocephalus dhawanii sp. n. on the tobacco grasshopper, Atractomorpha crenulata (Fab.). Journal of Orthopteran Research, v.9, p.67-70, 2000.

KAAKEH, W.; REID, B.L.; BENNETT, G.W. Horizontal transmission of the entomopathogenic fungus Metarhizium anisopliae (Imperfect Fungi: Hyphomycetes) and hydramethylon among German cockroaches (Dictyoptera: Blattellidae). Journal of Entomological Science, v.31, n.4, p.378-390, 1996.

KAAKEH, W.; REID, B.L.; BOHNERT, T.J.; BENNET, G.W. Toxicity of imidacloprid in the German cockroach (Dictyoptera: Blattellidae), and the synergism between imidacloprid and Metarhizium anisopliae (Imperfect Fungi: Hyphomycetes). Journal of Economic Entomology, v.90, n.2, p.473-482, 1997a.

KAAKEH, W.; REID, B.L.; KAAKEH, N. BENNETT, G.W. Rate determination, indirect toxicity, contact activity and residual persistence of lufenuron for the control of the German cockroach (Dictyoptra: Blattellidae). Journal of Ecomomic Entomology, v.90, n.2, p.510-522, 1997b.

KING, J.E.; BENNETT, G.W. Mortality and developmental abnormalities induced by two juvenile hormone analogs on nymohal German cockroaches (Dictyoptera: Blattellidae). Journal of Economic Entomology, v.81, n.1, p.225-227, 1988. 
KING, J.E.; BENNETT, G.W. Comparative sterilizing and ovicidal activity of fenoxycarb and hydroprene in adults and oothecae of the German cockroach (Dictyoptera: Blattellidae). Journal of Medical Entomology, v.27, p.643-645, 1990.

KLEESPIES, R.G.; TIDONA, C.A.; DARAI, G. Characterization of a new Iridovirus isolated from crickets and investigations on the host range. Journal of Invertebrate Pathology, v.73, p.84-90, 1999.

KOEHLER, P.G.; PATTERSON, R.S. Effects of chitin synthesis inhibitors on German cockroaches (Orthoptera: Blattellidae) mortality and reproduction. Journal of Economic Entomology, v.82, n. 1, p.143-148, 1989.

KOEHLER, P.G.; PATTERSON, R.S. Incorporation of pyriproxyfen in a German cockroach (Dictyoptera: Blattellidae) management program. Journal of Economic Entomology, v.84, n.3, p.917-921, 1991.

KOEHLER, P.G.; PATTERSON, R.S.; MARTIN, W.R. Susceptibility of cockroaches (Dictyoptera: Blattellidae, Blattidae) to infection by Steinernema carpocapse. Journal of Economic Entomology, v.85, n.4, p.1184-1187, 1992.

KOPANIC Junior, R.J.; SCHAL, C. Coprophagy facilitates horizontal transmission of bait among cockroaches (Dictyoptera: Blattellidae). Environmental Entomology, v.28, n.3, p.431-438, 1999.

KOPANIC Junior., R.J.; SHELDON, B.W.; WRIGHT, C.G. Cockroaches as vectors of Slamonella: laboratory and field trails. Journal of Food Protection, v.57, n.2, p.125-132, 1994. 
KRAMER, R.D.; KOEHLER, P.G.; PATTERSON, R.S. Morphogenetic effects of hydroprene on German cockroaches (Orthoptera: Blattellidae). Journal of Economic Entomology, v.82, n.1, p.163-170, 1989.

KRAMER, R.D.; KOEHLER, P.G.; PATTERSON, R.S. Effects of hydroprene exposure onthe physiology and insecticide susceptibility of German cockroaches (Orthoptera: Blattellidae). Journal of Economic Entomology, v.83, n.6, p.2310-2316, 1990.

KULSHRESTHA, V.; PATHAK, S.C. Aspergillosis in German cockroach Blattella germanica (L.) (Blattoidea: Blattellidae). Mycopathologia, v.139, p.75-78, 1997.

LACEY, C.M.; LACEY, L.A.; ROBERTS, D.R. Route of invasion and histopathology of Metarhizium anisopliae in Culex quinquefasciatus. Journal of Invertebrate Pathology, v.52, n.1, p.108-118, 1988.

LACEY, L.A.; FRUTOS, R.; KAYA, H.K.; VAIL, P. Insect pathogens as biological control agents: do they have a future? Biological Control, v.21, n.3, p.230-248, 2001.

LEVINE, N.D. The protozoan phylum Apicomplexa, v.1. Boca Raton, Fl: CRC Press, 1988a. 203p.

LEVINE, N.D. Progress in taxonomy of the Apicomplexa Protozoa. Journal of Protozoology, v.35, n.4, p.518-528, 1998b.

LOPES, R.B. Seleção de fungos entomopatogênicos e controle de Frankliniella occidentalis (Thysanoptera: Thripidae). Piracicaba, 1999. 72p. Dissertação (Mestrado) - Escola Superior de Agricultura "Luiz de Queiroz”, Universidade de São Paulo. 
MACHADO, V.E.; DIEHL-FLEIG, E.; SILVA, M.E.; LUCCHESE, M.E. Reações observadas em colônias de algumas espécies de Acromyrmex (Hymenoptera: Formicidae) quando inoculados com fungos entomopatogênicos. Ciência e Cultura, v.40, n.11, p.1106-1108, 1988.

MARICONI, F.A.M. As baratas. In: MARICONI, F.A.M. (Ed.). Insetos invasores de residências. Piracicaba: FEALQ, 1999. v.6, p.13-33.

MARTI Junior., O.G.; LALANNE-CASSOU, B.; SILVAIN, J.F.; KERMARREC, A.; SIMMONS, A.M. Ectoparasitic nematodes (Aphelenchoidoidea: Acugutturidae) of Lepidoptera and Blattodea in Guadeloupe. Nematology, v.2, n.6, p.669-684, 2000.

MATHUR, N.; KHERA, S.; GANDHI, S.; GUPTA, R. Susceptibility of the cockroach Periplaneta americana to Stainernema carpocapse: histopathological changes in the cockroach midgut. Indian Journal of Nematology, v.26, n.2, p.183-188, 1997.

MATZGER, R. Behavior. In: RUST, M.K.; OWENS, J.M.; REIERSON, D.A. (Ed.). Understanding and controlling the German cockroach New York: Oxford University Press, 1995. cap.3, p.49-76.

MOHAN, C.M.; LAKSHMI, K.A.; DEVI, K.U. Laboratory evaluation of the patogenicity of three isolates of the entomopathogenic fungus Beauveria bassiana (Bals.) Vuillemin on the American cockroach (Periplaneta americana). Biocontrol Science and Technology, v.9, n.1, p.29-33, 1999.

MOINO Junior., A.; ALVES, S.B. Efeito de imidacloprid e fipronil sobre Beauveria bassiana (Bals.) Vuill. e Metarhizium anisolpiae (Metsch.) Sorok. e no comportamento de limpeza de Heterotermes tenuis (Hagen). Anais da Sociedade Entomológica do Brasil, v. 27, n.4, p.611-619, 1998. 
MORAN, N.A.; TELANG, A. Bacteriocyte-association symbionts of insects. Bioscience, v.48, n.4, p.295-304, 1998.

MÜLLER-GRAF， C.D.M.; JOBET, E.; CLOAREC, A.; RIVAULT, C.; VAN BAALEN, M.; MORAND, S. Population dynamics of host-parasite interactions in a cockroach-oxyuroid system. Oikos, v.95, p.431-440, 2001.

MULLINS, D.E.; COCHRAN, D.G. Nutritional ecology of cockroaches. In: SLANSKY, JR.; RODRIGUIZ, J.G. (Ed.). Nutritional ecology of insects, mites, spiders and related invertebrates. New York: John Wiley, 1987. p.885-902.

NEVES, P.J.; ALVES, S.B. Controle associado de Cornitermes cumulans (Kollar, 1832) (Isoptera: Termitidae) com Metarhizium anisopliae, Beauveria bassiana e imidacloprid. Scientia Agricola, v.56, n.2, p.305-311, 1999.

NOLASCO, S. A vida secreta das baratas. Vetores\&Pragas, v.2, n.5, p.14-15, 1999.

OI, D.H.; PEREIRA, R.M.; STIMAC, J.L.; WOOD, L.A. Field applications of Beauveria bassiana for control of the red imported fire ant (Hymenoptera: Formicidae). Journal of Economic Entomology, v.87, n.3, p.623-630, 1994.

PACHAMUTHU, P.; KAMBLE, S.T. In vivo study on combined toxicity of Metarhizium anisopliae (Deuteromycotina: Hyphomycetes) strain ESC-1 with sublethal doses of chlorpyrifos, propetamphos and cyfluthrin against German cockroach (Dictyoptera: Blattellidae). Journal of Economic Entomology, v.93, n.1, p.60-70, 2000. 
PACHAMUTHU, P.; KAMBLE, S.T.; YUEN, G.Y. Virulence of Metarhizium anisopliae (Deuteromycotina: Hyphomycetes) strain ESC-1 to the German cockroach (Dictyoptera: Blattellidae) and its compatibility with insecticides. Journal of Economic Entomology, v.92, n.2, p.340-346, 1999.

PAI, H.H; KO, Y.C.; CHEN, E.R. Cockroaches (Periplaneta americana and Blattella germanica) as potential mechanical disseminators of Entamoeba hisolytica. Acta Tropica, v.87, p.355-359, 2003.

PATHAK, S.C.; KULSHRESTHA, V. Experimental aspergillosis in the German cockroach Blattella germanica: a histopathological study. Mycopathologia, v.143, p.13-16, 1998.

PATOUREL, G. Secondary transmission of fipronil toxicity between Oriental cockroaches Blatta orientalis L. in arenas. Pest Management Science, v.56, p.732$736,2000$.

PETERSON, R.K.D.; SHURDUT, B.A. Human health risks from cockroaches and cockroach management: a risk analysis approach. American Entomologist, v.45, n.3, p.142-148, 1999.

POSEY, D.A. Etnoentomologia de tribos indígenas da Amazônia. In: RIBEIRO, D. (Ed.) Suma Etnológica Brasileira, v.1- Etnobiologia. Petrópolis: Vozes/Finep, 1986. cap.14, p.251-271.

RADEK, R. Light and electron microscopic study of a Rickettsiella species from the cockroach Blatta orientalis. Journal of Invertebrate Pathology, v.76, p.249-256, 2000 . 
RADEK, R.; FABEL, P. A new entomopoxivirus from a cockroach: light and electron microscopy. Journal of Invertebrate Pathology, v.75, p.19-27, 2000.

RAHMET-ALLA, M.; ROWLEY, A.F. Studies on the pathogenicity of different strains of Bacillus cereus for the cockroach, Leucophaea maderae. Journal of Invertebrate Pathology, v.53, p.190-196, 1989.

REID, B.L.; APPEL, A.G.; DEMARK, J.J.; BENNETT, G.W. Oral toxicity, formulation effects, and field performance of flufenoxuron against the German cockroach (Dictyoptera: Blattellidae). Journal of Economic Entomology, v.85, n.4, p.11941200, 1992.

RIDDIFORD, L.M.; AJAMI, A.M.; BOARE, C. Effectiviness of insect growth regulators in the control of populations of the German cockroach. Journal of Economic Entomology, v.68, n.1, p.46-48, 1975.

RIVAULT, C.; CLOAREC, A.; SRENG, L. Cuticular extracts inducing aggregation in the German cockroach, Blattella germanica (L.). Journal of Insect Physiology, v.44, n.10, p.909-918, 1998.

ROBINSON, W.H. Urban entomology: Insect and mite pests in the human environment. London: Chapman\&Hall, 1996. 430p.

ROSALES, E.A.C. Efeito de derivados de meliáceas e isolados de fungos entomopatogênicos sobre o cupim subterrâneo Heterotermes tenuis (Hagen, 1858) (Isoptera: Rhinitermitidae). Piracicaba, 2001. 133p. Tese (Doutorado) - Escola Superior de Agricultura "Luiz de Queiroz", Universidade de São Paulo. 
ROSS, M.H. COCHRAN, D.G. Response of late-instar Blattella germanica (Dictyoptera: Blattellidae) to dietary insect growth regulators. Journal of Economic Entomology, v.83, n.6, p.2295-2305, 1990.

ROSS, M.H.; COCHRAN, D.G. Effects on German cockroach nymphs of contact exposure to IGR's singly and in combination. Entomologia Experimentalis et Applicata, v.61, p.117-122, 1991.

ROSS, M.H.; MULLINS, D.E. Biology. In: RUST, M.K.; OWENS, J.M.; REIERSON, D.A. (Ed.). Understanding and controlling the German cockroach New York: Oxford University Press, 1995. cap.2, p.21-47.

SAKUMURA, M.; FUKAMI, H. The aggregation pheromone of the German cockroach, Blattella germanica (L.) (Dictyoptera: Blattellidae): isolation and identification of the attractant components of the pheromone. Applied Entomology and Zoology, v.25, p.355-368, 1990.

SCHAL, C. Relation among efficacy of insecticides, resistance levels and sanitation in the control of the german cockroach (Dictyoptera: Blattellidae). Journal of Economic Entomology, v.81, n.2, p.536-544, 1988.

SCHAL, C.; HAMILTON, R.L. Integrated suppression of synathropic cockroaches. Annual Review of Entomology, v.35, p.521-551, 1990.

SCHNEIDER-ORELLI, O. Entomologisches Praktikum: Einfuehrung in die land und forstwirtschaftliche Insektekunde. Aarau: Zweite Aufl., 1947. 237p.

SERRA-FREIRE, N.M. Protozoários parasitos de baratas. Vetores\&Pragas, v.2, n.5, p.16-19, 1999. 
SILVA, M.E.; DIEHL-FLEIG, E. Avaliação de diferentes linhagens de fungos entomopatogênicos para o controle da formiga Atta sexdens piriventris (Santischi, 1919) (Hymenoptera: Formicidae). Anais da Sociedade Entomológica do Brasil, v.17, n.2, p.263-269, 1988.

SILVERMAN, J.; VITALE, G.I.; SHAPAS, T.J. Hydramethylon uptake by Blattella germanica (Orthoptera: Blattellidae) by coprophagy. Journal of Economic Entomology, v.84, n.1, p.176-180, 1991.

SINGH, P.; MOORE, R.F. Handbook of insect rearing. Amsterdam: Elsevier, 1985. v.1, 488p.

SNELLER, V.P. Inhibition of Dirofilaria immitis in gregarine-infected Aedes aegypti: premilinary observations. Journal of Invertebrate Pathology, v.34, n.1, p.62-70, 1979.

ST. LEGER, R.J; COOPER, R.M.; CHARNLEY, A.K. Characterization of chitinase and chitobiase produced by the entomopathogenic fungus Metarhizium anisopliae. Journal of Invertebrate Pahtology, v.58, n.3, p.415-426, 1991.

STAAL, G.B. Insect growth regulators with juvenile hormone activity. Annual Review of Entomology, v.20, p.417-460, 1975.

STEENBERG, T.; JENSEN, K.M.V.; SMIT, P.H. Entomopathogenic fungi for control of German cockroach (Blattella germanica) and other synathropic cockroaches. Bulletin OILB SROP, v.21, n.4, p.145-150, 1997.

SYNGENTA. Salmonela: uma bactéria de muitos vetores. Focus Saúde Pública, n.30, p.10-11, 2001. 
TAMAI, M.A.; ALVES, S.B.; ALMEIDA, J.E.M.; FAION, M. Avaliação de fungos entomopatogênicos para o controle de Tetranychus urticae Koch (Acari: Tetranychidae). Arquivos do Instituto Biológico, v.69, n.3, p.77-84, 2002a.

TAMAI, M.A.; ALVES, S.B.; FAION, M., PADULA, L.F. Toxicidade de produtos fitossanitários para Beauveria bassiana (Bals.) Vuill. Arquivos do Instituto Biológico, v.69, n.3, p. 89-96, 2002 b.

TSAI, Y.H.; CAHILL, K.M. Parasites of the German cockroach (Blattella germanica L.) in New York city. The Journal of Parasitology, v.56, n.2, p.375-377, 1970.

VERRETT, J.M.; GREEN, K.B.; GAMBLE, L.M.; CROCHEN, F.C. A hemocoelic Candida cockroach (Dictyoptera: Blattidae). Journal of Economic Entomology, v.80, n.6, p.1205-1212, 1987.

VESTERGAARD, S.; GILLESPIE, A.T.; BUTT, T.M.; SCHREITER, G.; EILENBERG, J. Pathogenicity of the Hyphomycete fungi Verticillium lecanii and Metarhizium anisopliae to the western flower thrips, Frankliniella occidentalis. Biocontrol Science and Technology, v.5., p.185-192, 1995.

WEAVER, J.E.; BEGLEY, J.W.; KONDO, V.A. Laboratory evaluation of Alsystin against the German cockroach (Orthoptera: Blattellidae): effects on immature stages and adult sterility. Journal of Economic Entomology, v.77, n.2, p.313-317, 1984.

WEONDONG, H.; JIEUN, C.; CHAESIK, L.; HYUNWOOK, C.; KEUNSHIK, B.; JIHYEOK, C.; CHINAM, S. Insecticidal effect of Baccilus sp. isolate on Periplaneta americana. Korean Journal of Entomology, v.30, n.4, p.275-282, 2000 . 
WICKHAM, J.C. Conventional insecticides. In: RUST, M.K.; OWENS, J.M.; REIERSON, D.A. (Ed.). Understanding and controlling the German cockroach New York: Oxford University Press, 1995. cap.6, p.109-147.

WIKEL, S.K. Immune responses to arthropods and their products. Annual Review of Entomology, v.27, p.21-48, 1982.

WIRTZ, R.A. Allergic and toxic reactions to non-stinging arthropods. Annual Review of Entomology, v.29, p.47-69, 1984.

ZEMAN, P.; KYSELOVA, M.; RUPES, V.; WIMMER, Z.; VRBA, Z. Management of a German cockroach population with a juvenoid bait formulation: an experiment in residential buildings. Entomologia Experimentalis et Applicata, v.62, p.47-53, 1992.

ZIMMERMANN, G. The entomopathogenic fungus Metarhizium anisopliae and its potential as a biocontrol agent. Pesticide Science, v.37, p.375-379, 1993.

ZUKOWSKI, K.; BAJAN, C. Studies of the usefulness of Beauveria bassiana for erradication of cockroaches (Blattella germanica L.). Roczniki Panstwowego Zakladu Higieny, v.47, n.3, p-343-349, 1996.

ZUKOWSKI, K.; BAJAN, C. Laboratory determination of the activity of insecticidal fungus Paecilomyces farinosus in reducing the number of cockroaches (Blattella germanica L.). Roczniki Panstwowego Zakladu Higieny, v.48, n.2, p-133-138, 1997.

ZUREK, L.; KEDDIE, B.A. Contribution of the colon and colonic bacterial flora to metabolism and development of the americam cockroach Periplaneta americana L., Journal of Insect Physiology, v.42, n.8, p.743-748, 1996. 
ZUREK, L.; WATSON, D.W.; SCHAL, C. Synergism between Metarhizium anisopliae (Deuteromycota: Hyphomycetes) and borc acid against the German cockroach (Dictyoptera: Blattellidae). Biological Control, v.23, p.296-302, 2002. 